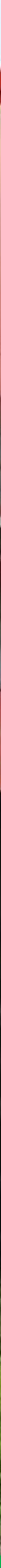

\title{
Handelsverkeer in de mestmarkt: opties voor interventies
}

Tanja de Koeijer, Carolien de Lauwere, Harry Luesink, Henri Prins 



\section{Handelsverkeer in de mestmarkt: opties voor interventies}

Tanja de Koeijer, Carolien de Lauwere, Harry Luesink, Henri Prins

Dit onderzoek is uitgevoerd door Wageningen Economic Research in opdracht van en gefinancierd door het ministerie van Landbouw, Natuur en Voedselkwaliteit, in het kader van het Beleidsondersteunend Onderzoeksprogramma Agro, thema 'Mest en Milieu' (projectnummer BO-20-004-122)

Wageningen Economic Research

Wageningen, augustus 2018

RAPPORT

2018-057

ISBN 978-94-6343-043-2 
Koeijer, T.J. de, C.C. de Lauwere, H.H. Luesink en H. Prins, 2018. Handelsverkeer in de mestmarkt: opties voor interventies. Wageningen, Wageningen Economic Research, Rapport 2018-057. 54 blz.; 20 fig.; 1 tab.; 13 ref.

Het ministerie van Landbouw, Natuur en Voedselkwaliteit zoekt naar handelingsperspectieven om de kans op fraude op de mestmarkt te verkleinen. Dat kan door lagere mestafzetkosten en door het invoeren van tegengesteld belang bij export.

Het aanpakken van de hoge mestafzetkosten, kan gerealiseerd worden door het aanbod te verkleinen of de vraag te vergroten. Uit de opties is vooral de verwerking van een grotere hoeveelheid mest met bijbehorende adequate handhaving realistisch.

De aanwezigheid van tegengestelde belangen tussen de aanbieder van mest en de afnemer ten aanzien van de hoeveelheid mineralen is een remmende factor voor fraude. Deze ontbreekt bij de export doordat in het buitenland geen mineralenboekhouding hoeft te worden verantwoord.

Afstemming met buitenland hierover zou ook hier tegengestelde belangen kunnen creëren en zo de fraudeprikkel verkleinen.

The Ministry of Agriculture, Nature and Food Quality is looking for action strategies to reduce the risk of fraud in the manure market. This can be done by means of lower manure disposal costs and by introducing a competing interest for exports.

The high costs of manure disposal can be tackled by reducing supply or increasing demand. Processing a larger amount of manure, with adequate corresponding enforcement, is the most realistic of the options.

The presence of competing interests between the manure supplier and the buyer as regards the amount of minerals serves to inhibit fraud. This is lacking in the case of exports because no mineral accounting needs to be approved abroad. Here too, co-ordination with other countries could create competing interests and thus reduce the incentive to defraud.

Trefwoorden: mest, handel, prijzen, fraude, markt

Dit rapport is gratis te downloaden op https://doi. org/10.18174/458034 of op www. wur. nl/economicresearch (onder Wageningen Economic Research publicaties).

(C) 2018 Wageningen Economic Research

Postbus 29703, 2502 LS Den Haag, T 07033583 30, E communications.ssg@wur.nl, www. wur. nl/economic-research. Wageningen Economic Research is onderdeel van Wageningen University \& Research.

\section{(cc) BY-NC}

Wageningen Economic Research hanteert voor haar rapporten een Creative Commons Naamsvermelding 3.0 Nederland licentie.

(c) Wageningen Economic Research, onderdeel van Stichting Wageningen Research, 2018 De gebruiker mag het werk kopiëren, verspreiden en doorgeven en afgeleide werken maken. Materiaal van derden waarvan in het werk gebruik is gemaakt en waarop intellectuele eigendomsrechten berusten, mogen niet zonder voorafgaande toestemming van derden gebruikt worden. De gebruiker dient bij het werk de door de maker of de licentiegever aangegeven naam te vermelden, maar niet zodanig dat de indruk gewekt wordt dat zij daarmee instemmen met het werk van de gebruiker of het gebruik van het werk. De gebruiker mag het werk niet voor commerciële doeleinden gebruiken.

Wageningen Economic Research aanvaardt geen aansprakelijkheid voor eventuele schade voortvloeiend uit het gebruik van de resultaten van dit onderzoek of de toepassing van de adviezen.

Wageningen Economic Research is ISO 9001: 2008 gecertificeerd.

Wageningen Economic Research Rapport 2018-057 | Projectcode 2282200295

Foto omslag: Eddy Teenstra 


\section{Inhoud}

Woord vooraf $\quad 5$

Samenvatting $\quad 6$

$\begin{array}{lll}\text { S.1 } & \text { Belangrijkste uitkomsten } & 6\end{array}$

$\begin{array}{lll}\text { S.2 Overige uitkomsten } & 7\end{array}$

$\begin{array}{ll}\text { S.3 Methode } & 7\end{array}$

$\begin{array}{ll}\text { Summary } & 8\end{array}$

$\begin{array}{lll}\text { S.1 Key findings } & 8\end{array}$

S.2 Complementary findings 9

$\begin{array}{lll}\text { S.3 Method } & 9\end{array}$

1

$\begin{array}{lr}\text { Inleiding } & 10\end{array}$

$\begin{array}{lll}1.1 & \text { Aanleiding } & 10\end{array}$

$\begin{array}{lll}1.2 & \text { Doel- en vraagstelling } & 10\end{array}$

$\begin{array}{lll}1.3 \text { Aanpak } & 10\end{array}$

$2 \quad$ Nederlandse mestmarkt $\quad 11$

2.1 Inleiding 11

$\begin{array}{lll}2.2 & \text { Omvang vraag en aanbod } & 11\end{array}$

$\begin{array}{lll}2.3 & \text { Inzoomen op de mestmarkt van } 2015 & 14\end{array}$

$\begin{array}{lll}2.4 & \text { Transport en bemonstering dikke fractie } & 16\end{array}$

$\begin{array}{lll}2.5 & \text { Prijsvorming } & 19\end{array}$

$\begin{array}{lll}2.6 & \text { Synthese } & 22\end{array}$

3 Effect van de organisatie van de mesthandel op fraude en mestprijzen 24

$3.1 \quad$ Belangen actoren op de mestmarkt $\quad 24$

3.2 Analyse aan- en afvoerstromen van mest in de mesthandel 25

$\begin{array}{lll}3.3 & \text { Effect mesthandel op de mestprijs } & 27\end{array}$

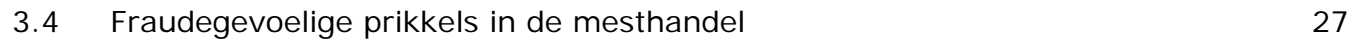

$\begin{array}{lll}3.5 & \text { Synthese } & 28\end{array}$

$\begin{array}{llr}\text { Resultaten interviews en workshop } & 29\end{array}$

4.1 Mogelijkheden om te frauderen $\quad 29$

4.2 Prikkels die fraude in de hand kunnen werken $\quad 31$

4.3 Hoe vaak treedt fraude in de mesthandel op?

4.4 Synthese $\quad 32$

$5 \quad$ Oplossingen om fraudedruk te verminderen $\quad 34$

5.1 Potentiële oplossingen en reflectie op haalbaarheid 34

5.2 Synthese 36

$\begin{array}{ll}\text { Conclusies } & 38\end{array}$

$\begin{array}{ll}\text { Literatuur en websites } & 39\end{array}$ 
Bijlage 1 Effect van verplichte mestverwerking op de afzetprijs van mest

Bijlage 2 Aanvoer en afvoer van mest van vervoerders (in $1.000 \mathrm{~kg}$ mest) in 2015 naar mestsoort

Bijlage 3 Fosfaat- en stikstofgehalten in de aangevoerde en afgevoerde mest ( kg per 1.000 kg mest) bij vervoerders in 2015 naar mestsoort

Bijlage 4 Resultaten interviews en workshop 


\section{Woord vooraf}

Versterking van de naleving van de Meststoffenwet is een van de speerpunten in het mestbeleid, onder andere omdat uit handhavingsactiviteiten van de NVWA en RVO.nl blijkt dat er gefraudeerd wordt. Uitgaande van de veronderstelling dat de hoge afzetkosten een prikkel zijn tot fraude, zocht het ministerie van Economische Zaken als voorganger van het huidige ministerie van Landbouw, Natuur en Voedselkwaliteit naar handelingsopties om de mestafzetkosten zo laag mogelijk te houden en fraudeprikkels en -mogelijkheden zo veel mogelijk weg te nemen.

Begin 2017 heeft het ministerie Wageningen Economic Research gevraagd om te verkennen of het door overheidsingrijpen mogelijk is om de mestmarkt beter en eerlijker te laten werken. Dit onderzoek toont aan dat de belangrijkste opties die hieraan bijdragen, zijn:

1. het ingrijpen in de mestmarkt gericht op het verlagen van de mestafzetprijs waardoor de fraudeprikkel wordt weggenomen. Hiertoe kan de overheid de verplichte mestverwerkingspercentages verhogen zodat krapte op de binnenlandse markt ontstaat. Hierdoor kan de handhaving zich focussen op de meststromen met betrekking tot mestverwerking. Extra mestverwerking zorgt ook voor een versnelling van de transitie naar een perspectiefvolle verwaarding van mest waardoor de fraudeprikkel uiteindelijk volledig kan worden weggenomen.

2. voor de controle van de mineralenboekhouding afstemming zoeken met het buitenland aangezien de export een belangrijk fraudegevoelige factor in het handelsverkeer op de mestmarkt betreft.

In de eerste helft van 2017 zijn naast deskresearch ook interviews en een workshop gehouden. Wij zijn de geïnterviewden en deelnemers aan de workshop zeer erkentelijk voor de door hen verstrekte informatie met betrekking tot het reilen en zeilen in de mesthandel en mogelijke oplossingen.

Daarnaast danken we $\mathrm{H}$. Schollaart als de contactpersoon vanuit het ministerie voor de opdracht en het geschonken vertrouwen.

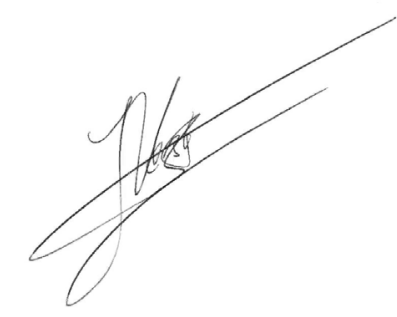

Prof.dr.ir. J.G.A.J. (J ack) van der Vorst

Algemeen Directeur Social Sciences Group (SSG)

Wageningen University \& Research 


\section{Samenvatting}

\section{S.1 Belangrijkste uitkomsten}

Het ministerie van Landbouw, Natuur en Voedselkwaliteit zoekt naar handelingsperspectieven om de kans op fraude op de mestmarkt te verkleinen. De twee belangrijkste handelingsperspectieven zijn: 1) het realiseren van lagere mestafzetkosten en 2 ) het realiseren van intrinsieke controlemechanismen bij elk transport. Dit mechanisme is bij de meeste transporten aanwezig behalve bij de export.

De mestafzetkosten nemen af indien de mestafzetprijs kan worden verlaagd. Dit kan door een belangrijke vergroting van de vraag of vermindering van het aanbod. Een vermindering van het aanbod op de reguliere mestmarkt kan worden bereikt door een verhoging van de mestverwerkingsplicht. Deze zou zodanig moeten worden vergroot dat de mestafzetkosten op de reguliere mestmarkt niet langer een prikkel tot fraude vormen. De handhaving kan zich vervolgens focussen op de meststromen met betrekking tot mestverwerking. Een neveneffect is dat de innovatie in mestverwerking, gericht op het verwaarden van mest, hierdoor versneld kan plaatsvinden. Hierdoor kunnen op termijn de kosten voor mestverwerking afnemen waardoor ook bij mestverwerking de fraudeprikkel kan afnemen (paragraaf 2.5).

Op elke markt zijn er tegengestelde belangen. In het geval van goederen met een negatieve waarde zoals momenteel bij mest het geval is, wil de leverancier een zo laag mogelijke prijs voor het afzetten van de mest terwijl de afnemer juist zo veel mogelijk toe wil krijgen. Op de mestmarkt geldt dit niet alleen voor de mestafzetprijs maar ook voor de mineraleninhoud in de mest. Deze tegengestelde belangen ten aanzien van de mineraleninhoud vormen een belangrijke remmende factor voor fraude omdat de afnemer de leverantie controleert. Echter, bij de export van mest ontbreekt dit tegengestelde belang omdat de afnemer geen mineralenboekhouding hoeft te verantwoorden. Hierdoor maakt het de afnemer niet uit dat er minder mineralen in de mest zitten dan op papier is aangegeven en is zijn belang dus neutraal (figuur S.1). Hierdoor vormt de export een belangrijk fraudegevoelig element in de mestmarkt en kan op papier meer mest worden geëxporteerd dan in de praktijk. Doordat als gevolg van het niet exporteren van mest er vervolgens 'zwarte' mest ontstaat leidt dit ook tot een versterkte fraudeprikkel elders op de mestmarkt doordat deze illegaal in de Nederlandse landbouw wordt afgezet (paragraaf 4.1). Om dit probleem op te lossen, is afstemming met het buitenland noodzakelijk. Dit zou mogelijk in Europees verband in het kader van gezamenlijke mestbeleid kunnen worden aangepakt (paragraaf 3.1).
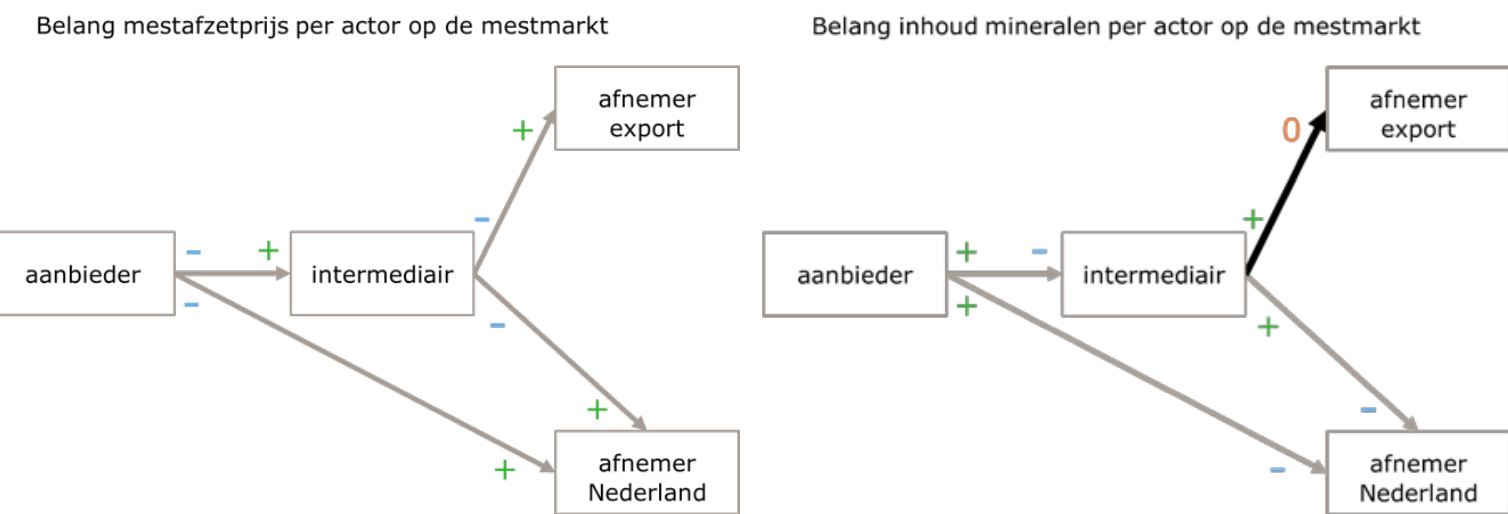

Figuur S.1 Positief dan wel negatief belang bij hogere mestafzetprijs (links) en bij hogere mineraleninhoud (rechts) in de mest per onderscheiden actor op de mestmarkt 


\section{S.2 Overige uitkomsten}

Overige handelingsperspectieven voor de overheid om fraudeprikkels af te remmen betreffen:

1. meer gerichte controles op basis van bijvoorbeeld onwaarschijnlijke fosfaatgehaltes in de mest en een onwaarschijnlijke omvang van meststromen gegeven de capaciteit van bijvoorbeeld hygiënisatie of het vervoer (paragraaf 3.2);

2. het aanpassen van wetgeving ten aanzien van de geaccepteerde mineralengehaltes per mestsoort zodat controlerende instanties daadwerkelijk kunnen handhaven als onwaarschijnlijke gehaltes in de mest worden gevonden, en zodat ze in staat worden gesteld om bewijslast te kunnen opbouwen bij mogelijk grote gevallen van fraude (paragraaf 3.2);

3. het verlagen van de mestafzetprijs door het beperken van het aanbod via een reductie van de dieraantallen. Voor de veehouderij is het echter momenteel bedrijfseconomisch aantrekkelijker om mest te verwerken dan minder dieren te houden (paragraaf 5.1).

Het handelen van mesthandelaren en - transporteurs heeft geen belangrijk kostenopdrijvend effect op de mestafzet. Het effect van de mesthandel op de mestprijs bestaat uit een toeslag gebaseerd op de kosten voor met name de distributie van de mest die vooral afhankelijk is van het aantal transportkilometers. Vanwege de onderlinge concurrentie liggen de kosten eerder onder dan boven de kostprijs (paragraaf 3.3).

Naast de aan- en afwezigheid van tegengestelde belangen remmen of versterken de volgende elementen in de organisatie van de mestmarkt de prikkel tot fraude:

1. De complexiteit van de meststromen in de mesthandel als gevolg van het mengen en opnieuw labellen van de meststromen, bemoeilijkt adequate controle waardoor de kans op fraude toeneemt (paragraaf 2.4).

2. Het gebrek aan voldoende afzetmogelijkheden, zoals vooral in 2015 het geval was, werkt fraude in de hand doordat de mest nauwelijks kon worden afgezet als gevolg van een verzadigde markt en schaarste aan mestverwerkingscapaciteit (paragraaf 2.3).

3. De bemonstering van dikke fractie vormde een belangrijk probleem omdat deze relatief eenvoudig kon worden gemanipuleerd en dus fraudegevoelig was, maar dit probleem is met de in 2017 ingevoerde onafhankelijke bemonstering aangepakt (paragraaf 2.4).

\section{S.3 Methode}

Omdat hoge mestafzetkosten een prikkel kunnen zijn tot fraude, zoekt het ministerie van Landbouw, Natuur en Voedselkwaliteit naar handelingsopties om de mestafzetkosten zo laag mogelijk te houden en fraudeprikkels en -mogelijkheden zo veel mogelijk weg te nemen. Hiertoe zijn de volgende onderzoeksvragen geanalyseerd:

1. In hoeverre heeft het handelen van mesthandelaren/-transporteurs/-distributeurs een kostenopdrijvend effect op de mestafzet?

2. In welke mate remt of versterkt de organisatie van de mestmarkt de prikkel tot fraude?

3. Wat zijn handelingsperspectieven voor de overheid om fraude(prikkels) als gevolg van de organisatie van de mesthandel af te remmen?

Voor de beantwoording van de onderzoeksvragen is gebruikgemaakt van databestanden van RVO over transporten van mest, is de totstandkoming van de mestafzetprijs beschreven en de rol van de mesthandel daarbij. Vervolgens zijn de elementen in de mesthandel die remmend of juist bevorderend werken op de kans op fraude onderzocht en zijn handelingsperspectieven geïnventariseerd en bediscussieerd. Daarbij is gebruikgemaakt van diepte-interviews met de betrokken actoren (drie met belangenorganisaties, vijf met mesttransporteurs, drie met akkerbouwers en vijf met veehouders) en een workshop met beleidsmakers van het ministerie van Economische Zaken en een deel van de genoemde actoren en deskresearch. 


\section{Summary}

\section{S.1 Key findings}

The Ministry of Agriculture, Nature and Food Quality is looking for action strategies to reduce the risk of fraud in the manure market. The two most important action strategies are: 1) reducing manure disposal costs and 2) putting in place intrinsic control mechanisms for each transport. This mechanism is in place in most manure transport, except in the case of exports.

The cost of manure disposal will decrease if the price can be lowered. This can be achieved by significantly increasing demand or reducing supply. A reduction in supply on the regular manure market can be achieved by increasing the manure processing obligation. This should be increased so that the cost of disposing of manure on the regular manure market is no longer an incentive for fraud. Enforcement can then focus on the manure flows in relation to manure processing. A side effect is that innovation in manure processing, aimed at valorising manure, can be accelerated as a result. This may eventually bring down the cost of manure processing and in turn lead to a reduced fraud incentive in this regard (section 2.5).

There are competing interests in every market. In the case of goods with a negative value (as is currently the case for manure) the supplier wants the lowest possible price for disposing of the manure, whereas the buyer wants to get as much as possible. In the manure market, this applies not only to the disposal price of manure but also to the mineral content of the manure. These competing interests regarding the mineral content are an important deterrent to fraud because the buyer controls the supply. However, in the case of exporting manure, this competing interest is lacking because the buyer does not have to conduct mineral accounting. As a result, buyers do not care that there are fewer minerals in the manure than is indicated on paper and their interest is therefore neutral (figure S.1). This makes exports an important element in the manure market that is susceptible to fraud, and more manure can be exported on paper than in practice. When manure is not exported, leading to 'black' manure, this in turn leads to an increased incentive for fraud elsewhere in the manure market because it is sold illegally in Dutch agriculture (section 4.1). In order to resolve this problem, it is necessary to co-ordinate with other countries. This could possibly be addressed at European level within the framework of a common manure policy (section 3.1).

Interest in manure price per player in the manure market

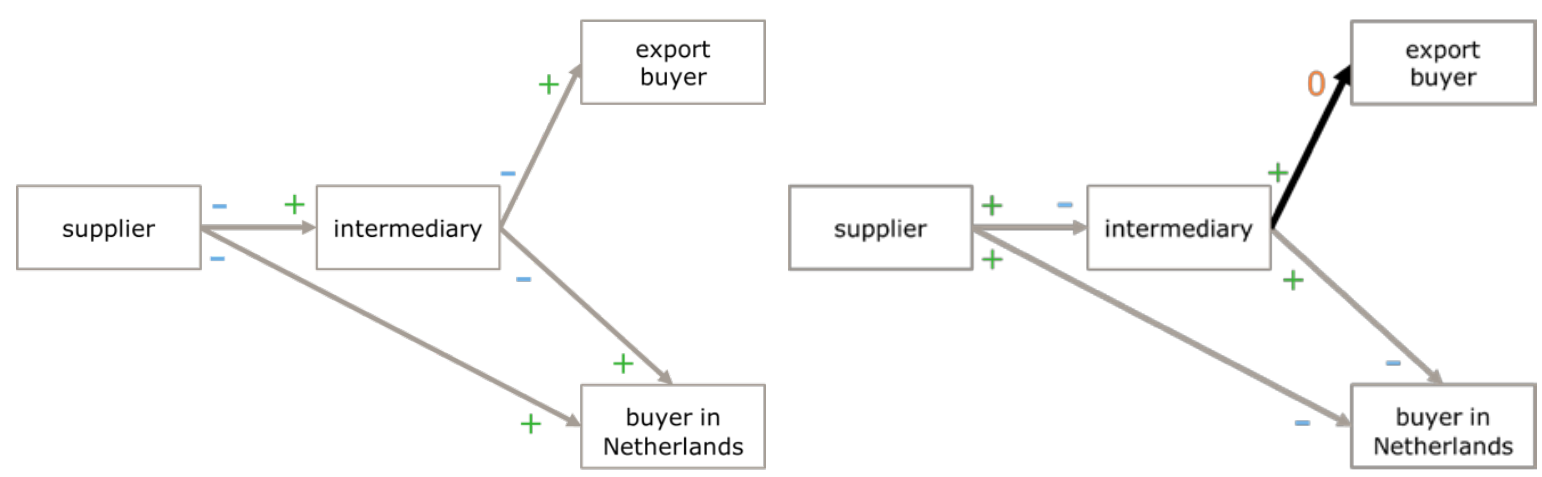

Figure S.1 Positive or negative interest in higher manure prices (left) and higher mineral content (right) in the manure for different players in the manure market 


\section{S.2 Complementary findings}

Other action strategies for the government to curb incentives to commit fraud are:

1. such things as more targeted checks on improbable phosphate levels in manure and/or an improbable volume of manure flows in view of the capacity for sanitising or transport(section 3.2);

2. adapting legislation on the acceptable mineral content for each type of manure so that control authorities can effectively enforce if improbable levels are found in the manure, and so that they are able to build up a burden of proof in the case of potentially major cases of fraud (section 3.2);

3. lowering the manure price by limiting supply by reducing the number of animals. However, it is currently more economically attractive for livestock farmers to process manure than to keep fewer animals (section 5.1)

The actions of manure dealers and shippers do not have a significant cost-increasing effect on manure sales. The effect of the manure trade on the price of manure consists of a surcharge based on the cost of distributing the manure, which depends mainly on the distance the manure has to be transported. Owing to competition, the cost tends to be lower than the cost price rather than higher (section 3.3).

In addition to the presence or absence of competing interests, the following elements in the organisation of the manure market can inhibit or reinforce the incentive for fraud:

1. The complexity of the manure flows in the manure trade (as a result of mixing and re-labelling manure flows) makes adequate control more difficult and therefore increases the risk of fraud (section 2.4).

2. The lack of sufficient outlets (as was particularly the case in 2015) encourages fraud because the manure could hardly be disposed of due to a saturated market and a scarcity of manure processing capacity (section 2.3).

3. Sampling viscous fraction was a major problem because it was relatively easy to manipulate and therefore susceptible to fraud, but this problem was addressed by the independent sampling introduced in 2017 (section 2.4).

\section{S.3 Method}

Because high manure disposal costs can be an incentive for fraud, the Ministry of Agriculture, Nature and Food Quality is looking for strategies to keep manure removal costs as low as possible and to remove as many incentives and opportunities for fraud as possible. To this end, the following research questions were analysed:

1. To what extent do the actions of manure dealers/shippers/distributors drive up the cost of manure marketing?

2. To what extent does the organisation of the manure market inhibit or strengthen the incentive for fraud?

3. What are the government's possible strategies for curbing fraud or the incentives to commit fraud resulting from the organisation of the manure trade?

To answer the research questions, we made use of the databases of the Netherlands Enterprise Agency (RVO) on the transport of manure. We have described how the manure disposal price was set, and the role of the manure trade in this. Subsequently, the elements in the manure trade that inhibit or actually promote the risk of fraud were investigated and the action strategies were inventoried and discussed. As part of this, in-depth interviews were conducted with the actors involved (three with interest groups, five with manure transporters, three with arable farmers and five with livestock farmers), and a workshop was held with policymakers from the Dutch Ministry of Economic Affairs and some of the aforementioned actors. The investigation also included desk research. 


\section{$1 \quad$ Inleiding}

\section{$1.1 \quad$ Aanleiding}

Versterking van de naleving van de Meststoffenwet is een van de speerpunten in het mestbeleid, onder andere omdat uit handhavingsactiviteiten van de NVWA en RVO.nl blijkt dat er gefraudeerd wordt. Uit recent onderzoek (De Koeijer et al., 2015) blijkt dat er een aanbodmarkt is van mest met vraag naar landbouwgrond als afzetruimte. De afnemer van mest ontvangt daarvoor een vergoeding. Voor de aanbieder van mest betekent dit een forse kostenpost. Algemeen wordt aangenomen dat hoge kosten een sterke prikkel vormen om te frauderen. Ondernemers klagen bij het ministerie van Landbouw, Natuur en Voedselkwaliteit dat fraude een ongelijk speelveld veroorzaakt in het voordeel van fraudeurs waardoor ondernemers die niet frauderen moeilijk kunnen concurreren met wel frauderende collega's.

Uitgaande van de veronderstelling dat de hoge afzetkosten een prikkel zijn tot fraude, heeft het ministerie van LNV aan Wageningen Economic Research gevraagd om te verkennen wat de voor- en nadelen van de huidige organisatie van de mesthandel zijn. Op basis daarvan heeft het ministerie gevraagd opties te benoemen voor interventies in de mestmarkt en/of de organisatie van de mesthandel die de risico's op fraude effectief kunnen beïnvloeden.

\subsection{Doel- en vraagstelling}

Het doel van het onderzoek is te verkennen of het door overheidsingrijpen mogelijk is om het speelveld in de mesthandel te versterken in het nadeel van frauderende ondernemers.

Daartoe zijn de volgende onderzoeksvragen geanalyseerd:

1. In hoeverre heeft het handelen van mesthandelaren/-transporteurs-/distributeurs een kostenopdrijvend effect op de mestafzet?

2. In welke mate remt of versterkt de organisatie van de mestmarkt de prikkel tot fraude?

3. Wat zijn handelingsperspectieven voor de overheid om fraude(prikkels) als gevolg van de organisatie van de mesthandel af te remmen?

\subsection{Aanpak}

Voor de beantwoording van onderzoeksvragen zijn de volgende activiteiten uitgevoerd:

1. Analyse van databestanden over het transport van mest. De databestanden zijn afkomstig van RVO en voorbewerkt door het CBS (hoofdstuk 2 en 3).

2. Op basis van de bij Wageningen Economic Research beschikbare expertise is beschreven hoe de mestafzetprijs tot stand komt en wat de bijbehorende rol van de mesthandel is (hoofdstuk 2 en 3 ).

3. Het effect van fraude op de prijsontwikkeling van de mest is op basis van theoretische economische principes toegelicht beredeneerd en beschreven (hoofdstuk 2).

4. Op basis van 16 diepte- interviews met belanghebbenden (drie met belangenorganisaties, vijf met mesttransporteurs, drie met akkerbouwers en vijf met veehouders) zijn de belangrijkste prikkels en mogelijke oplossingen in de mesthandel geïnventariseerd ten aanzien van eventuele fraude en kostenopdrijving (hoofdstuk 4).

5. Aanvullend is een workshop gehouden met beleidsmakers en een deel van de geïnterviewde stakeholders om de uitkomsten van de interviews te bespreken. In deze workshop zijn ook de perspectiefvolle oplossingen die tijdens de interviews naar voren kwamen verder besproken en uitgewerkt ( hoofdstuk 5).

De conclusies van het onderzoek zijn samengevat in hoofdstuk 6. 


\section{$2 \quad$ Nederlandse mestmarkt}

\section{$2.1 \quad$ Inleiding}

Om de Nederlandse mestmarkt te beschrijven wordt als eerste in paragraaf 2.2 ingegaan op de omvang van het aanbod op de Nederlandse mestmarkt en de vraag naar mest. Daarbij worden de gewichtshoeveelheden zowel uitgedrukt in fosfaat als in mest. De hoeveelheid fosfaat is van belang omdat de wetgeving ten aanzien van de hoeveelheden mest die verwerkt moeten worden, aangrijpen op fosfaat. Daarnaast worden de hoeveelheden uitgedrukt in gewichtseenheden mest. De aandelen verwerkte mest uitgedrukt in gewichtseenheden kunnen een ander beeld geven aangezien de fosfaatconcentraties in de verschillende mestsoorten in belangrijke mate verschillen. Dit is voor het transport van mest een belangrijk gegeven. Bij een lagere fosfaatconcentratie moeten meer transporten worden verricht voor het transport van eenzelfde hoeveelheid fosfaat.

Paragraaf 2.3 zoomt in meer detail in op de vraag en het aanbod op de mestmarkt van 2015. Per transport moet een Vervoersbewijs Dierlijke Mest (VDM) worden opgemaakt. Op de VDM wordt aangegeven hoeveel mest wordt vervoerd, wat de stikstof- en fosfaatconcentraties zijn en wat de afkomst en de bestemming van het transport is. Vanuit het oogpunt van eventuele kostenopdrijving door de mesthandel en mogelijke fraude vormen de transporten het grootste risico, omdat ze enerzijds kosten met zich meebrengen en anderzijds rondom de opmaak van de VDM's fraude kan optreden. Omdat dit volgens RVO en NVWA met name bij transport en bemonstering van de dikke fractie voorkomt, worden het transport en de bemonstering van de dikke fractie behandeld in paragraaf 2.4 .

De prijsvorming van mest en de effecten van fraude en de omvang van de beschikbare mestverwerkingscapaciteit worden in paragraaf 2.5 geschetst. Paragraaf 2.6 sluit het hoofdstuk af met een synthese.

Een hoge mestafzetprijs betekent een sterk negatieve mestprijs In het rapport wordt zowel gesproken over de mestafzetprijs als over de mestprijs. Bij het schetsen van de prijsvorming op de mestmarkt is gebruikgemaakt van de mestprijs om aan te sluiten bij de gangbare economische uitleg van de werking van vraag en aanbod en het effect daarvan op de prijs. Het bijzondere van de huidige mestmarkt is dat de prijs van mest negatief is. Dit maakt het hanteren van dit begrip relatief complex waardoor waar mogelijk gebruik wordt gemaakt van de term 'mestafzetprijs'. Deze prijs reflecteert de prijs die de aanbieder van mest moet betalen om de mest af te zetten. Een hoge mestafzetprijs geeft dus aan dat hij hoge mestafzetkosten heeft. Een hoge mestafzetprijs geeft ook aan dat de prijs van mest sterk negatief is.

\subsection{Omvang vraag en aanbod}

lets meer dan de helft van de geproduceerde mest komt op de mestmarkt Globaal wordt de helft van de hoeveelheid geproduceerde fosfaat in dierlijke mest op het eigen bedrijf afgezet. De andere helft wordt op de mestmarkt afgezet (figuur 2.1). Van het deel dat op de mestmarkt wordt afgezet wordt circa de helft in Nederland afgezet, de andere helft wordt geëxporteerd. Zoals figuur 2.1 ook laat zien, gaat een klein deel van de mest naar hobbybedrijven in Nederland en is er voor een deel van de mest geen afzetbestemming bekend.

De berekening van de afzet op de mestmarkt is uitgevoerd op basis van het CDM-protocol ${ }^{1}$ voor de monitoring mestmarkt (Van den Born et al., 2009) met als doel om vast te stellen of de geproduceerde hoeveelheid fosfaat in de mest, ook daadwerkelijk is afgezet. De hoeveelheid mest

\footnotetext{
1 Beschrijving van de vereiste methodiek en de benodigde data voor het monitoren van de mestmarkt.
} 
waarvan de bestemming onbekend is, kon voor varkensmest volledig worden verklaard uit de onzekerheden rondom de productie en afzet van mest. ${ }^{2}$ Belangrijke onzekerheden betreffen de dieraantallen, de mestproductie per dier per jaar, de gehaltemetingen, verkeerd labellen op VDM's, het nog niet compleet zijn van VDM-registraties en de overschrijding van de gebruiksnormen.

Mln. kg fosfaat

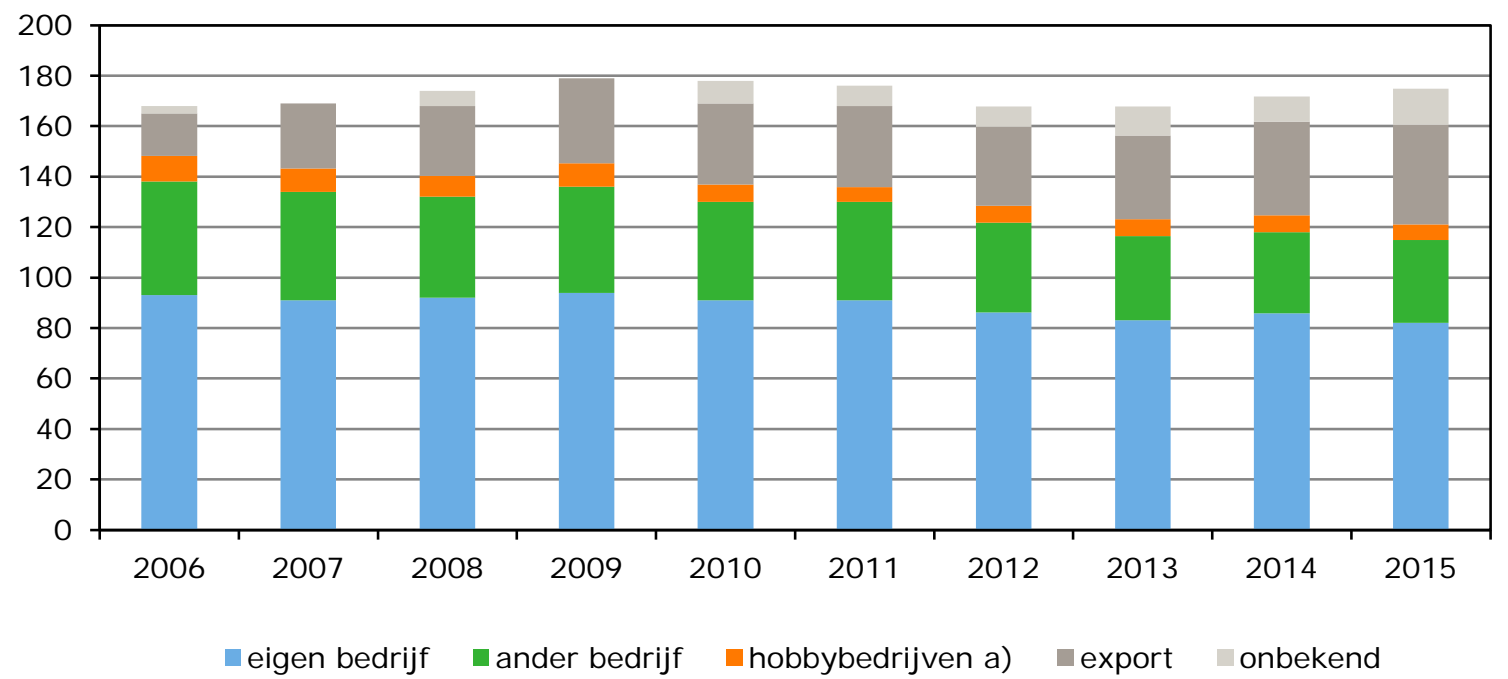

Figuur 2.1 Afzet forfaitair fosfaat uit dierlijke mest naar bestemming voor de jaren 2006 tot en met 2015

a) Inclusief afzet bij particulieren en natuurterrein

Bronnen: CBS Landbouwtelling en EZ-RVO, bewerking Wageningen Economic Research; Jaar 2014: CDM (2015) en Van Bruggen et al. (2016).

\section{De plaatsingsruimte in de Nederlandse landbouw bedraagt twee derde van de geproduceerde mest}

De productie van fosfaat in dierlijke mest varieert de laatste jaren tussen de 161 (2012) en 180 (2015) $\mathrm{mln}$. kg fosfaat (figuur 2.2). ${ }^{3}$ Op de cultuurgrond op landbouwbedrijven in Nederland is ruimte om vanaf 2015 ( $5^{\mathrm{e}}$ actieprogramma nitraatrichtlijn) $135 \mathrm{mln}$. $\mathrm{kg}$ fosfaat te plaatsen binnen de fosfaatgebruiksnormen (Oenema, 2015). In een aantal situaties wordt geen fosfaat uit dierlijke mest aangewend, omdat makkelijk opneembare fosfaat is vereist. In die gevallen wordt de fosfaat in de vorm van kunstmest toegediend. Deze hoeveelheid wordt geschat op 5-10 mln. kg fosfaat (Monitoring mestmarkt, 2012; De Koeijer et al., 2014). Daarnaast wordt ook fosfaat toegediend in de vorm van 'overige organische meststoffen'. In 2009 (recentere gegevens niet beschikbaar) was deze hoeveelheid $8 \mathrm{mln}$. $\mathrm{kg}$ fosfaat (Luesink et al., 2011). Dit betekent dat de volledige fosfaatgebruiksruimte op landbouwbedrijven (maximale vraag naar fosfaat meststof) in Nederland niet kan worden benut voor de afzet van fosfaat uit dierlijke mest. Door het gebruik van fosfaatkunstmest en overige organische mest blijft er vanaf 2015 jaarlijks een maximale vraag vanuit de Nederlandse landbouw over van circa $120 \mathrm{mln}$. kg fosfaat uit dierlijke mest.

\section{Plaatsingsruimte voor dierlijke mest volledig benut}

Er wordt circa $120 \mathrm{mln}$. $\mathrm{kg}$ fosfaat in de Nederlandse landbouw afgezet. Daarmee is vrijwel de volledige plaatsingsruimte voor fosfaat in de Nederlandse landbouw benut (figuur 2.2). Dit betekent dat ongeacht de prijs voor mest er niet meer fosfaat uit dierlijke mest in de Nederlandse landbouw kan worden afgezet. Daarbovenop is er nog ruimte om circa 6 à $7 \mathrm{mln}$. kg fosfaat uit dierlijke mest in Nederland af te zetten op hobbybedrijven, bij particulieren en op natuurterreinen. Dit betekent dat er

2 www. monitoringmestmarkt.nl

3 Figuur 2.1 is gebaseerd op de forfaitaire fosfaatproductie. In de meeste jaren komt deze overeen met de achteraf gemeten werkelijke fosfaatproductie. In 2015 echter wijkt deze sterk af door de onverwacht hoge fosforgehalten in het gras. De forfaitaire productie is hierdoor $5 \mathrm{mln}$. $\mathrm{kg}$ fosfaat lager dan de werkelijke fosfaatproductie (figuur 2.2). 
in 2015 voor ongeveer 54 miljoen $\mathrm{kg}$ fosfaat uit dierlijke mest een andere bestemming moest worden gezocht.

\section{Eén derde moet worden geëxporteerd en/ of verwerkt}

De plaatsingsruimte voor mest is in de periode 2007-2015 met circa 25\% afgenomen als gevolg van strengere gebruiksnormen. Doordat de productie van fosfaat in dezelfde periode iets is toegenomen moet in 2015 circa 33\% van de geproduceerde hoeveelheid fosfaat buiten de Nederlandse landbouw worden afgezet (figuur 2.2). Dit betekent dat er in 2015 verwerkingscapaciteit ${ }^{4}$ nodig was voor circa $54 \mathrm{mln}$. $\mathrm{kg}$ fosfaat. Als de fosfaatproductie in de toekomst net zoveel varieert als in de voorgaande jaren, varieert de behoefte aan mestverwerkingscapaciteit bij de sinds 2015 van kracht geworden gebruiksnormen jaarlijks van 34-54 mln. kg fosfaat. Voor de mestverwerkingsindustrie is deze variatie een groot probleem omdat de verwerkingscapaciteit niet zo flexibel is. Om te zorgen dat altijd alle mest kan worden verwerkt, zou voor de meeste jaren een overcapaciteit nodig zijn. Dit betekent dat op de reguliere markt krapte zal ontstaan waardoor naast de reguliere dierlijke mestproducten meer kunstmest en/ of verwerkte mest wordt aangekocht. Hierdoor zal de mestafzetprijs op de reguliere mestmarkt minder negatief worden.

Als met de invoering van het fosfaatrechtenstelsel in 2018 de fosfaatproductie wordt beperkt tot het fosfaatplafond van $172,9 \mathrm{mln}$. $\mathrm{kg}$ fosfaat is dit probleem voor de mestverwerkingsindustrie kleiner. De benodigde mestverwerkingscapaciteit is in dat geval $47 \mathrm{mln}$. $\mathrm{kg}$ fosfaat.

\section{Huidige omvang verplichte mestverwerking heeft weinig effect op de mestmarkt.}

Binnen de mestwetgeving moet een deel van de mest die van het veehouderijbedrijf moet worden afgevoerd, verplicht worden verwerkt. Voor het jaar 2017 zijn de verplichte

mestverwerkingspercentages voor de mestgebieden zuid, oost en overig vastgesteld op respectievelijk 59, 52 en 10\%. Met deze mestverwerkingspercentages en de mestoverschotsituatie van 2015 is de omvang van de verplichte mestverwerking in 2017 35,2 mln. $\mathrm{kg}$ fosfaat (De Koeijer et al., 2017). Omdat in 2015 (voor de invoering van de genoemde verplichte mestverwerkingspercentages) reeds $40,5 \mathrm{mln}$. kg fosfaat werd verwerkt, heeft de verplichte mestverwerking in deze situatie weinig effect op de mestmarkt.

\section{$14 \mathrm{mln}$. kg fosfaat geen afzetbestemming in 2015}

In 2015 is 40,5 mln. ton fosfaat verwerkt (figuur 2.1). Er had echter $54 \mathrm{mln}$. ton fosfaat verwerkt moeten worden (figuur 2.2). Hierdoor was er in 2015 een tekort aan afzetmogelijkheden van bijna $14 \mathrm{mln}$. kg fosfaat. Dit tekort voor circa $15 \%$ van het aanbod van $93 \mathrm{mln}$. $\mathrm{kg}$ fosfaat $^{5}$ op de mestmarkt (bron: MAMBO) veroorzaakt een grote druk op de mestmarkt, omdat hiervoor binnen de gebruiksruimte in Nederland en de gerealiseerde export geen bestemming is. Dit betekent dat de mest waarvoor geen reguliere bestemming is, alleen op een frauduleuze manier kan worden afgezet of dient te worden opgeslagen. Overigens is het wel mogelijk dat het berekende tekort aan afzetmogelijkheden is overschat. De berekening van de productie en de afzet zijn uitgevoerd conform het protocol voor de monitoring mestmarkt. Daarbij spelen een aantal onzekerheden (zoals bijvoorbeeld ten aanzien van het aantal varkens en kippen) een rol (www.monitoringmestmarkt.nl). Hierdoor zou de werkelijke hoeveelheid aanzienlijk kleiner ${ }^{6}$ kunnen zijn.

\footnotetext{
4 Volgens de definitie van de meststoffenwet: export, verbranden en korrelen.

5 Fosfaatproductie min afzet op het eigen bedrijf.

6 De onzekerheden werken voornamelijk een kant uit (monitoring mestmarkt) waardoor de werkelijke hoeveelheid door de onzekerheden niet groter zal uitvallen.
} 
Mln. kg fosfaat

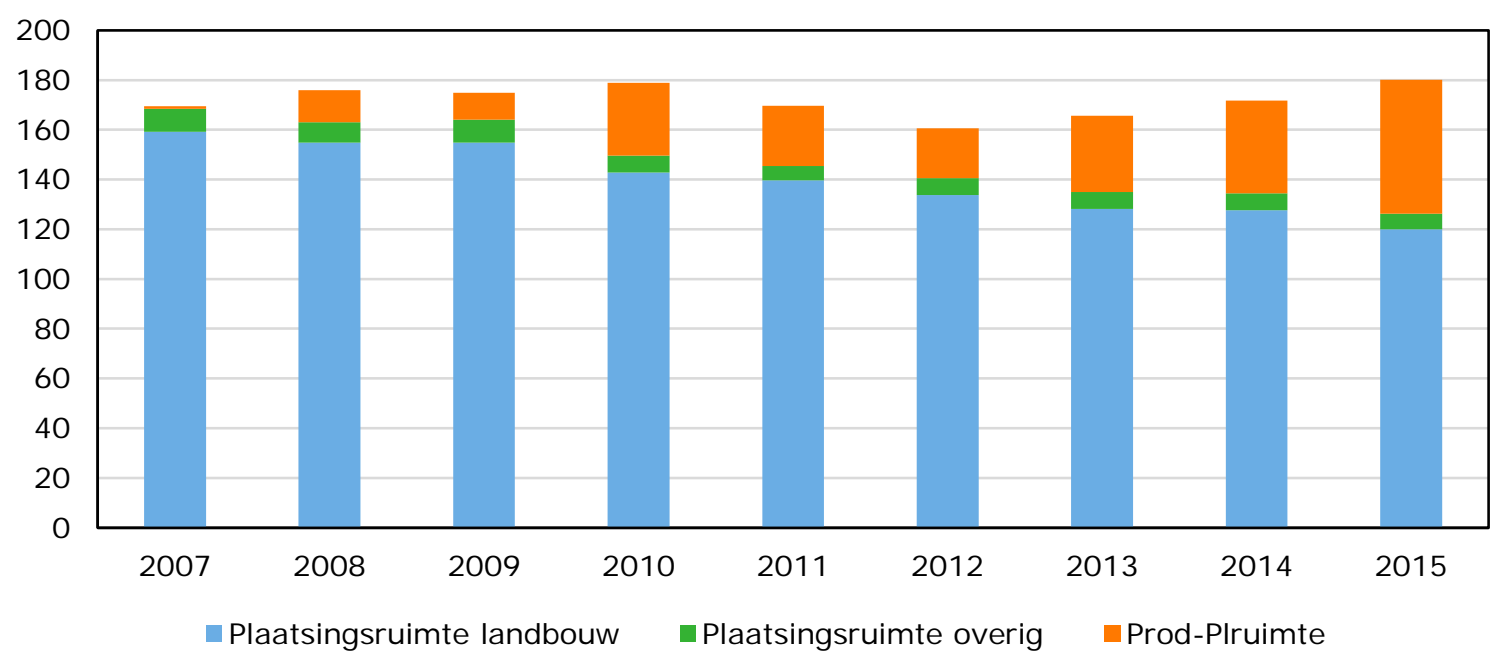

Figuur 2.2 De totale fosfaatproductie ( $\mathrm{mln}$. $\mathrm{kg}$ fosfaat) onderverdeeld in: 1 ) de plaatsingsruimte voor fosfaat in de Nederlandse landbouw, 2) de overige plaatsingsruimte ${ }^{7}$ in Nederland en 3 ) een restpost (productie minus plaatsingsruimte) waarvoor geen plaatsingsruimte is in Nederland $(\mathrm{mln} . \mathrm{kg}$ fosfaat $)^{8}$

\subsection{Inzoomen op de mestmarkt van 2015}

\section{Fosfaat}

Het aandeel mest dat verwerkt wordt verschilt per mestsoort. Van de $93 \mathrm{mln}$. kg fosfaat die in 2015 op de mestmarkt werd aangeboden, was bijna 30\% afkomstig van graasveemest, ruim 30\% van varkensmest en eveneens ruim 30\% van pluimveemest. De overige mest die aangeboden werd op de mestmarkt bestaat in hoofdzaak uit mest van vleeskalveren (figuur 2.3).

Zoals figuur 2.3 laat zien, werd de pluimveemest nagenoeg voor 100\% verwerkt. De verwerking bestaat uit export waarvan een deel vooraf is verwerkt door verbranding en door korrelen. Van varkensmest werd 30\% verwerkt. De verwerking van varkensmest bestond met name uit export van gescheiden dikke fractie. Van graasveemest werd $5 \%$ verwerkt. De verwerking van graasveemest bestond met name uit export van gescheiden dikke fractie.

\footnotetext{
7 Plaatsingsruimte bij hobbybedrijven, particulieren en natuur.

8 De productie in figuur 2.2 wijkt iets af van die in figuur 2.1. In figuur 2.1 is de forfaitaire hoeveelheid fosfaat vermeld, aangezien dit de hoeveelheid is waarop de veehouder wordt afgerekend. In figuur 2.2 is de achteraf berekende werkelijke fosfaatproductie gehanteerd. Deze kan jaarlijks verschillen door variatie in weer en de gevoerde voersoorten.
} 


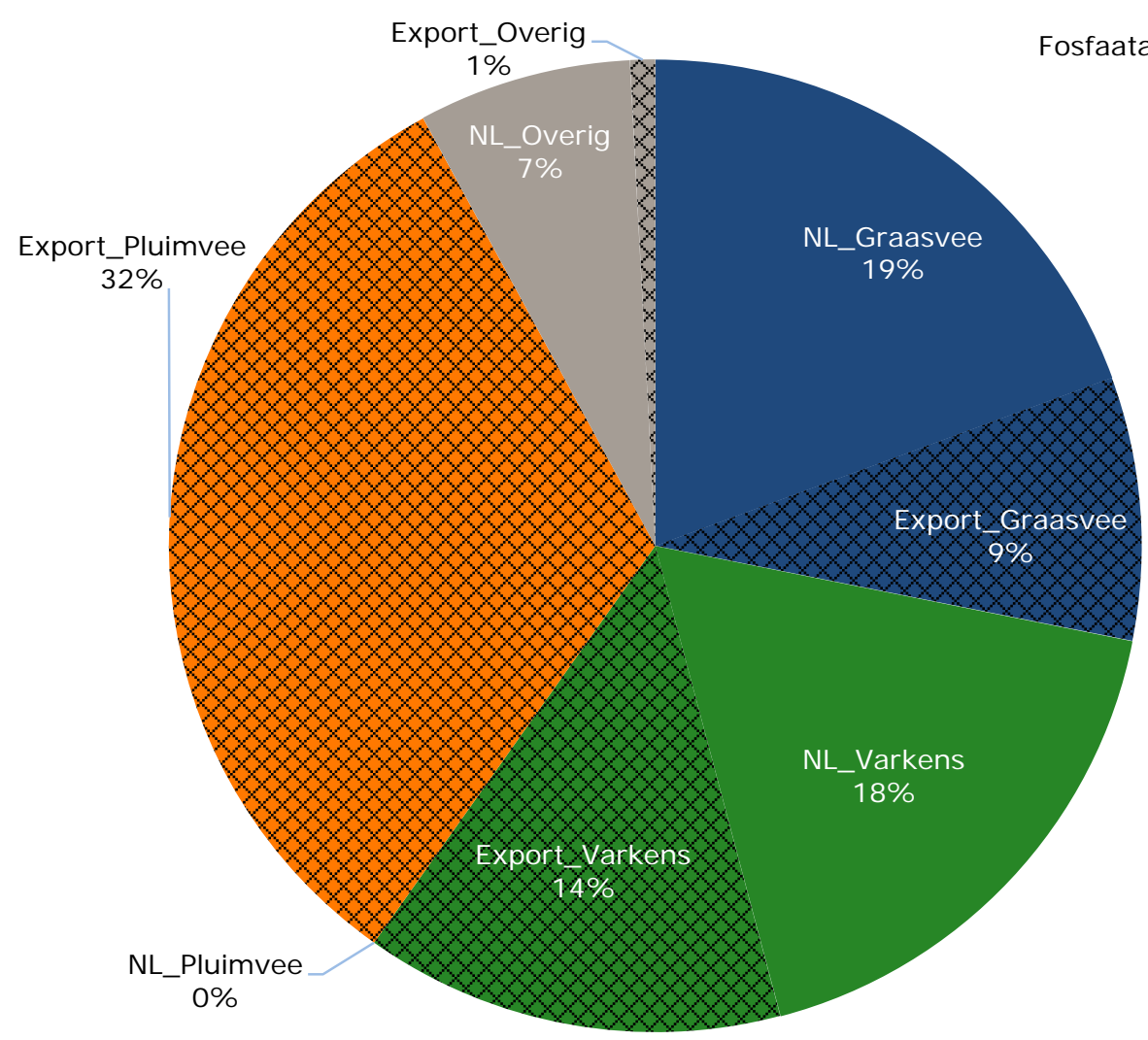

Figuur 2.3 Afzet van fosfaat van het bedrijfsoverschot van dierlijke mest in 2015 naar de bestemming Nederlandse landbouw en export (inclusief natuur, hobbybedrijven en particulieren) naar mestsoort

Bron: EZ-RVO, bewerking Wageningen Economic Research.

\section{Gewicht}

De $93 \mathrm{mln}$. kg fosfaat die in 2015 op de mestmarkt kwam was afkomstig uit $28 \mathrm{mln}$. ton mest, waarvan van $5 \mathrm{mln}$. ton tweemaal of vaker een VDM is opgemaakt (figuur 2.4). Dit geeft aan dat de meeste mest rechtstreeks van de aanbieder naar de afnemer wordt overgebracht zonder dat een intermediair tussentijds eigenaar werd van de mest. De verdeling van de mest op de mestmarkt is in gewichtseenheden op die van de overige mestsoorten na totaal anders dan die op basis van fosfaat. Was het aandeel pluimveemest bij fosfaat bijvoorbeeld 32\%, in gewichtsaandeel is het maar $7 \%$ (figuur 2.4). Graasveemest heeft het grootste aandeel in gewichtshoeveelheid met een aandeel van $44 \%$ met kort daarachter varkensmest met $41 \%$. 


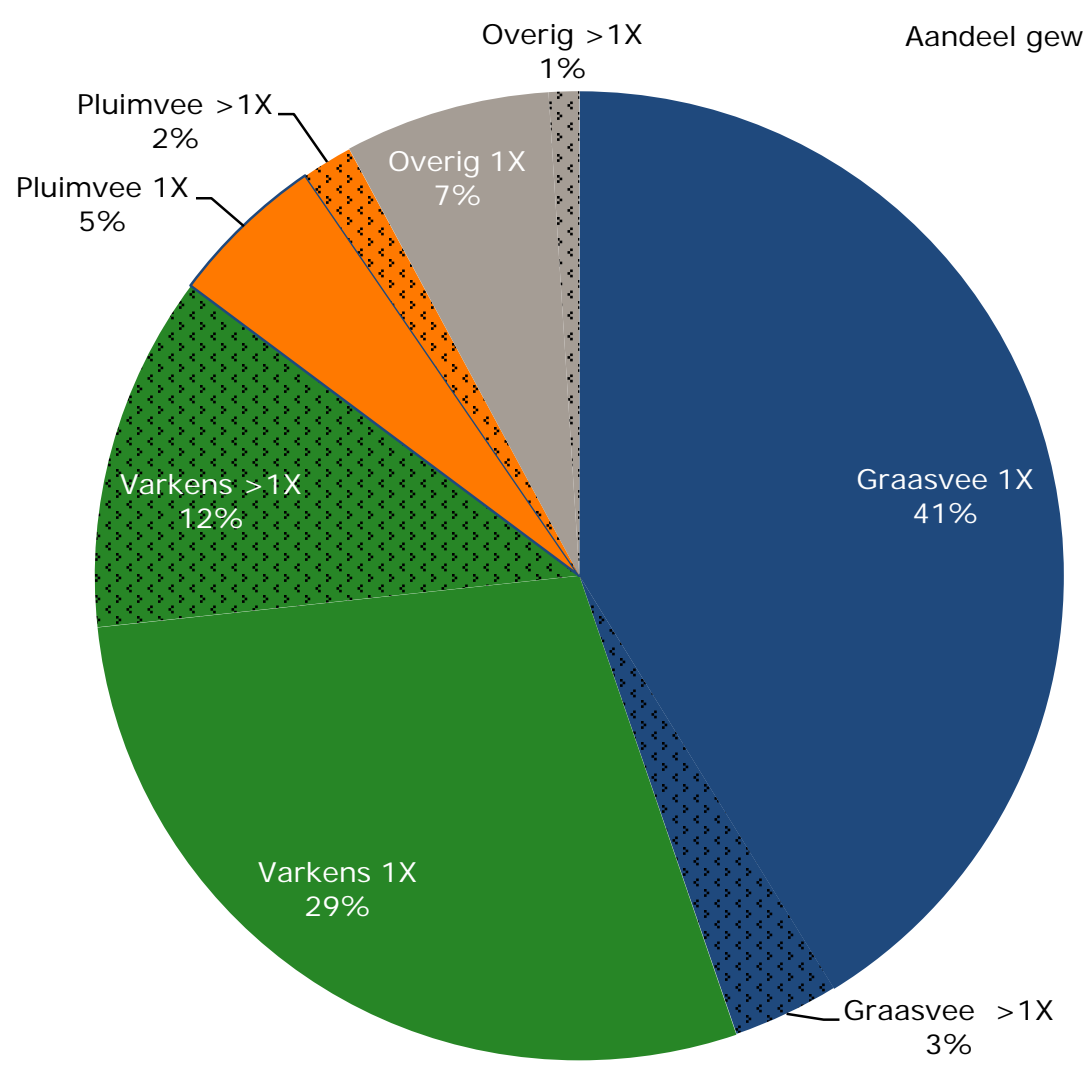

Figuur 2.4 Dierlijke mest in 2015 op de mestmarkt in gewichtshoeveelheid naar mestsoort en aantal malen op de mestmarkt Bron: EZ-RVO, bewerking Wageningen Economic Research.

\subsection{Transport en bemonstering dikke fractie}

Per mesttransport is het wettelijk verplicht om een Vervoersbewijs Dierlijke Mest (VDM) op te stellen waarin is aangegeven hoeveel mest van de ene actor naar de andere actor op de mestmarkt gaat. Deze VDM's worden door RVO verzameld zodat gecontroleerd kan worden of alle mest conform de wettelijke verplichtingen is afgezet. Voor het bepalen van de gehalten in een partij mest wordt deze voorafgaand aan het transport bemonsterd. ${ }^{9}$

Bij de bemonstering van vaste mest en de dikke fractie van gescheiden mest zijn de vrijheidsgraden groot. Dit komt doordat het bemonsteringsresultaat makkelijker te beïnvloeden is omdat een partij vaste mest minder homogeen is dan een partij drijfmest. Vanwege de sterk toenemende tendens om mest te scheiden (figuur 2.5) wordt in deze paragraaf daarom speciaal aandacht besteed aan de transporten van mest van dikke fractie.

\section{Sterke toename transporten dikke fractie van gescheiden mest}

In 2015 waren er ruim 24.000 transporten met dikke fractie van gescheiden rundveedrijfmest en ruim 32.500 transporten van dikke fractie van gescheiden varkensdrijfmest (EZ-RVO, 2016). Bijna 55\% van de transporten van dikke fractie was in de vorm van gemengde mest. Dat wil zeggen dat $55 \%$ van alle transporten met dikke fractie gemengd was met een andere mestsoort. Dit kon zowel dierlijke mest als overige organische mestsoorten betreffen. In 35\% van de transporten met dikke fractie was het aandeel van de dikke fractie $35 \%$ of minder.

\footnotetext{
${ }^{9}$ Hierop zijn uitzonderingen zoals bij: boer-boer transport, bij een afgekeurd monster en bij export vanaf het eigen bedrijf worden forfaits gehanteerd.
} 
De transporten (12.288 stuks) van 100\% dikke fractie hebben voor rundveedrijfmest een gewogen gemiddeld gehalte van $10 \mathrm{~kg}$ fosfaat per ton en voor varkensdrijfmest (13.892 transporten) van $22 \mathrm{~kg}$ fosfaat per ton (figuur 2.6 en 2.7).

\subsection{0 ton dikke fractie}

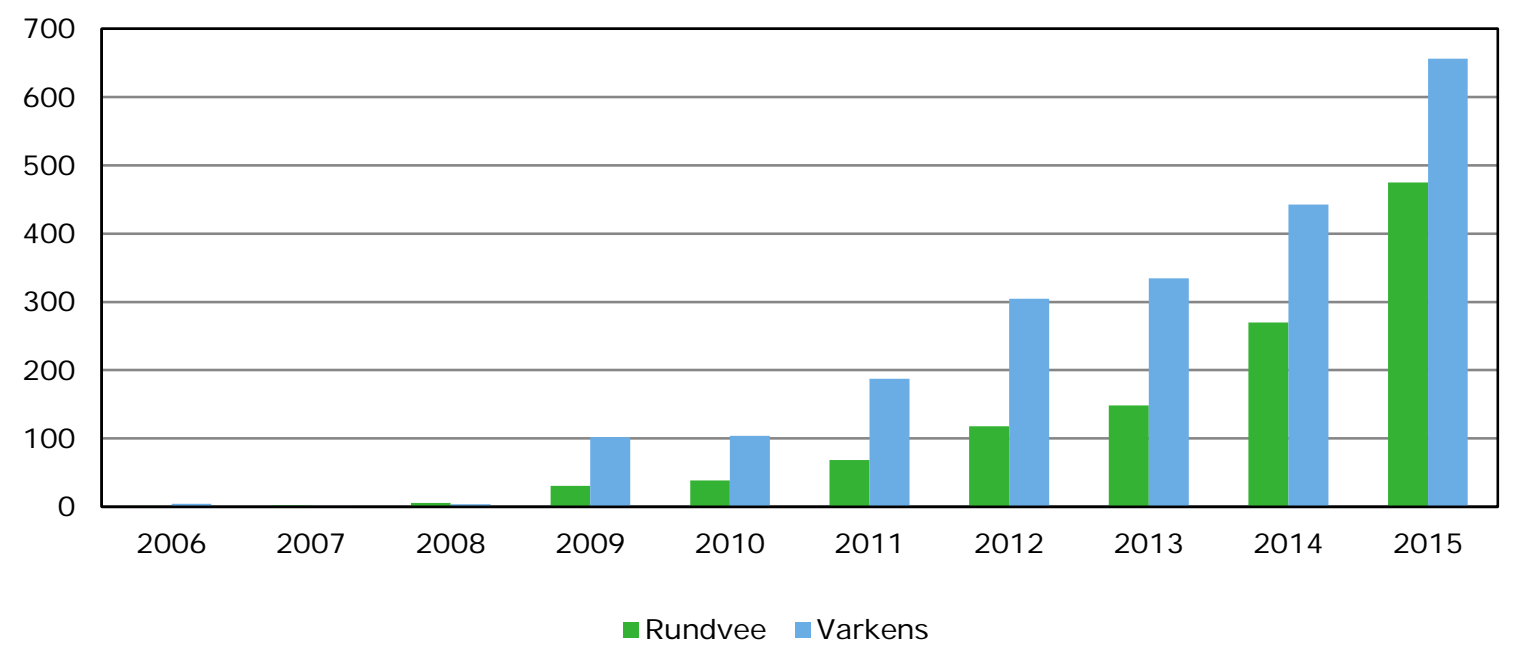

Figuur 2.5 Dikke fractie op de mestmarkt van gescheiden rundvee- en varkensdrijfmest naar jaar Bron: EZ-RVO, bewerking CBS en Wageningen Economic Research.

\section{Onwaarschijnlijk hoge gehalten}

Volgens expertise van WUR (Buisonje, 2017; persoonlijke mededeling) is in de dikke fractie van rundveedrijfmest en varkensmest een fosfaatgehalte van respectievelijk 2,5 tot 7 en 10 tot $30 \mathrm{~kg}$ fosfaat per ton te verwachten.

\section{Rundveemest}

Op basis van de VDM's waren de gehalten in gescheiden dikke fractie van rundveedrijfmest in 2015 gemiddeld meer dan een factor twee hoger dan de verwachting. Ruim 3\% van de monsters had in 2015 juist onwaarschijnlijk lage fosfaatgehalten in de dikke fractie; minder dan 2,5 kg fosfaat per ton. De meerderheid (72\%) van de monsters had in 2015 echter gehalten van meer dan $7 \mathrm{~kg}$ fosfaat per ton dikke fractie (figuur 2.8). De gehalten liepen op tot meer dan $100 \mathrm{~kg}$ fosfaat per ton dikke fractie. Opvallend is dat de mediaan (10 kg fosfaat per ton) exact uitkomt op het wettelijk forfait. Omdat het forfait van $9,8 \mathrm{~kg}$ fosfaat per ton relatief hoog is in vergelijking met de gangbare gehalten van 2,5 tot $7 \mathrm{~kg}$ per ton (Buisonje, 2017) is het lucratief om een monster in te sturen dat niet voldoet aan het minimale gewicht van 400 gram. In zo'n geval wordt het monster afgekeurd en wordt het forfaitaire gehalte gehanteerd. Omdat het forfaitaire gehalte hoger is dan het werkelijke gehalte levert dit voordeel op voor de mesttransporteur en/of de veehouder doordat ze dan minder mest hoeven af te voeren om aan de mestboekhouding te voldoen. 


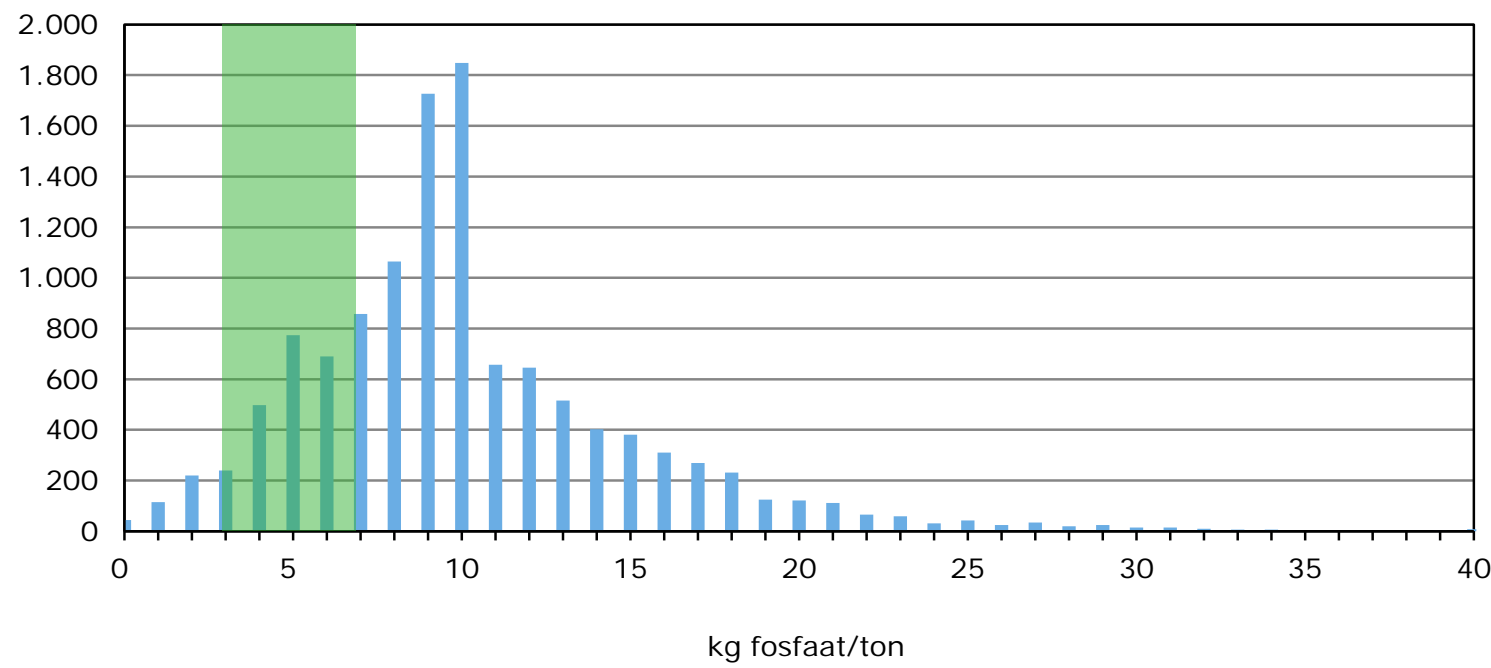

Figuur 2.6 Aantal transporten in 2015 bestaande uit 100\% dikke fractie van rundveedrijfmest per fosfaatgehalteklasse ( $\mathrm{kg}$ fosfaat/ton) en de waarschijnlijkheidsgrenzen van de fosfaatgehalten in de dikke fractie van rundveemest

Bron: EZ-RVO, bewerking CBS en Wageningen Economic Research.

\section{Varkensmest}

Ook bij de dikke fractie van gescheiden varkensdrijfmest komen onwaarschijnlijk lage en hoge fosfaatgehalten voor (figuur 2.7). Zo heeft $2 \%$ van de transporten in 2015 fosfaatgehalten van minder dan $10 \mathrm{~kg}$ fosfaat in de dikke fractie. Bij de dikke fractie van gescheiden varkensdrijfmest had $7 \%$ van de transporten in 2015 een hoger fosfaatgehalte dan de bovengrens van $30 \mathrm{~kg}$ fosfaat per ton (dit is dus veel minder dan bij de transporten van de dikke fractie van rundveedrijfmest waarvan ongeveer $70 \%$ onwaarschijnlijk hoge gehaltes had). Net als bij de dikke fractie van rundveemest is het ook hier weer opvallend dat de mediaan ( $21 \mathrm{~kg}$ fosfaat per ton) overeenkomt met het wettelijk forfait.

\section{Aantal transporten}

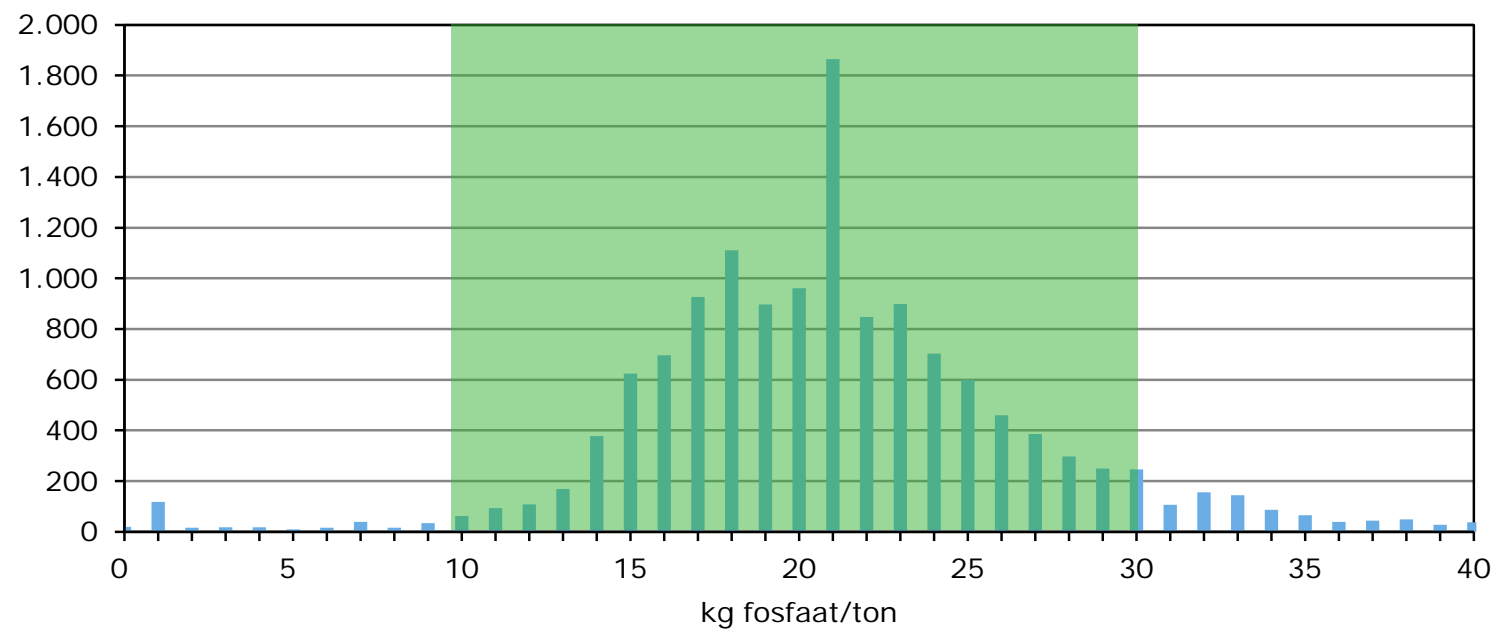

Figuur 2.7 Aantal transporten in 2015 bestaande uit 100\% dikke fractie van varkensdrijfmest per fosfaatgehalteklasse ( $\mathrm{kg}$ fosfaat/ton) en de waarschijnlijkheidsgrenzen van de fosfaatgehalten in de dikke fractie van varkensmest

Bron: EZ-RVO, bewerking CBS en Wageningen Economic Research. 


\section{Transporten dikke fractie bij beperkt aantal intermediairs}

Bij 50\% van alle transporten van dikke fractie zijn vervoerders (intermediairs) betrokken en bij 38\% van alle transporten van dikke fractie be-/verwerkers (De Koeijer et al., 2016). In totaal zijn er 97 vervoerders en 94 be-/verwerkers betrokken bij het transport van dikke fractie.

Er is één vervoerder die ruim 15\% voor zijn rekening neemt van alle transporten van dikke fractie (EZ-RVO, 2016). De tien vervoerders met in omvang de meeste transporten verzorgen bijna $40 \%$ van alle transporten van dikke fractie van gescheiden mest. Bij de be- en verwerkers is de verdeling van de transporten gelijkmatiger.

Geen enkele be- of verwerker neemt meer dan 4\% van alle transporten van dikke fractie voor zijn rekening. De tien be- en verwerkers met in omvang de meeste transporten, zijn betrokken bij $23 \%$ van alle transporten van dikke fractie van gescheiden mest.

\subsection{Prijsvorming}

Maximale prijs wordt bepaald door de prijs van het beste alternatief De prijs van een product wordt mede bepaald door de prijs van het alternatief waarvoor de afnemer kan kiezen. In het geval van mest is het alternatief kunstmest. Dit betekent dat de prijs van dierlijke mest niet boven de prijs voor kunstmest met een vergelijkbare bemestingswaarde kan liggen afgezien van verschillen in toedieningskosten. Op het moment dat dat wel het geval zou zijn, zouden de afnemers kiezen voor kunstmest en kan de dierlijke mest niet worden afgezet. ${ }^{10}$

Op basis hiervan zou verwacht mogen worden dat veehouders hun mest af kunnen zetten voor maximaal de prijs van kunstmest minus de extra benodigde opslag- en transportkosten van dierlijke mest. Indien er niet meer mest op de mestmarkt zou worden aangeboden dan gevraagd vanuit de Nederlandse landbouw zou dit inderdaad het geval zijn. In figuur 2.8 is deze situatie als voorbeeld aangegeven met het rode lijnstuk voor varkensmest in het zuidelijk zandgebied voor 2011 die de vraag vanuit de akkerbouw weergeeft. Indien er geen mestoverschot is, willen akkerbouwers betalen voor de mest. Naarmate de akkerbouwgebieden verder weg liggen, nemen de transportkosten toe waardoor de mestprijs van positief naar negatief omslaat. De mestprijs neemt bij toenemend aanbod af vanwege afnemende schaarste. Daar komt bij dat bij toenemend aanbod de mest over grotere afstanden moet worden getransporteerd, waardoor de kosten voor opslag en transport de vergoeding voor de bemestingswaarde overtreffen.

De vraag kan verder toenemen als ook de afzet in het buitenland tot de mogelijkheden behoort. Dit is het geval op het moment dat de veehouder niet alleen de opslag en transportkosten binnen Nederland maar ook die in het buitenland (inclusief de extra kosten voor export als gevolg van extra administratie en schoonmaakkosten van vrachtwagens ter voorkoming van ziekte-insleep) voor zijn rekening neemt. Hierdoor wordt de prijs voor de afzet van mest meer negatief wat betekent dat de kosten voor mestafzet voor de veehouder toenemen. Op een bepaald punt is het bij een grotere transportafstand niet langer rendabel om mest te hygiëniseren en te transporteren. Het is dan goedkoper om de mest te verwerken tot mestkorrels en deze vervolgens naar de verder weggelegen gebieden te exporteren. In bijlage 1 is de totstandkoming van de vraagcurve in meer detail uitgewerkt.

\footnotetext{
${ }^{10}$ In de praktijk kan deze grens iets afwijken doordat afnemers juist meer of minder voordelen toekennen aan dierlijke mest dan aan kunstmest bijvoorbeeld vanwege de organische stof die wel in dierlijke mest zit en niet in kunstmest, maar het effect hiervan op de prijs is niet groot.
} 


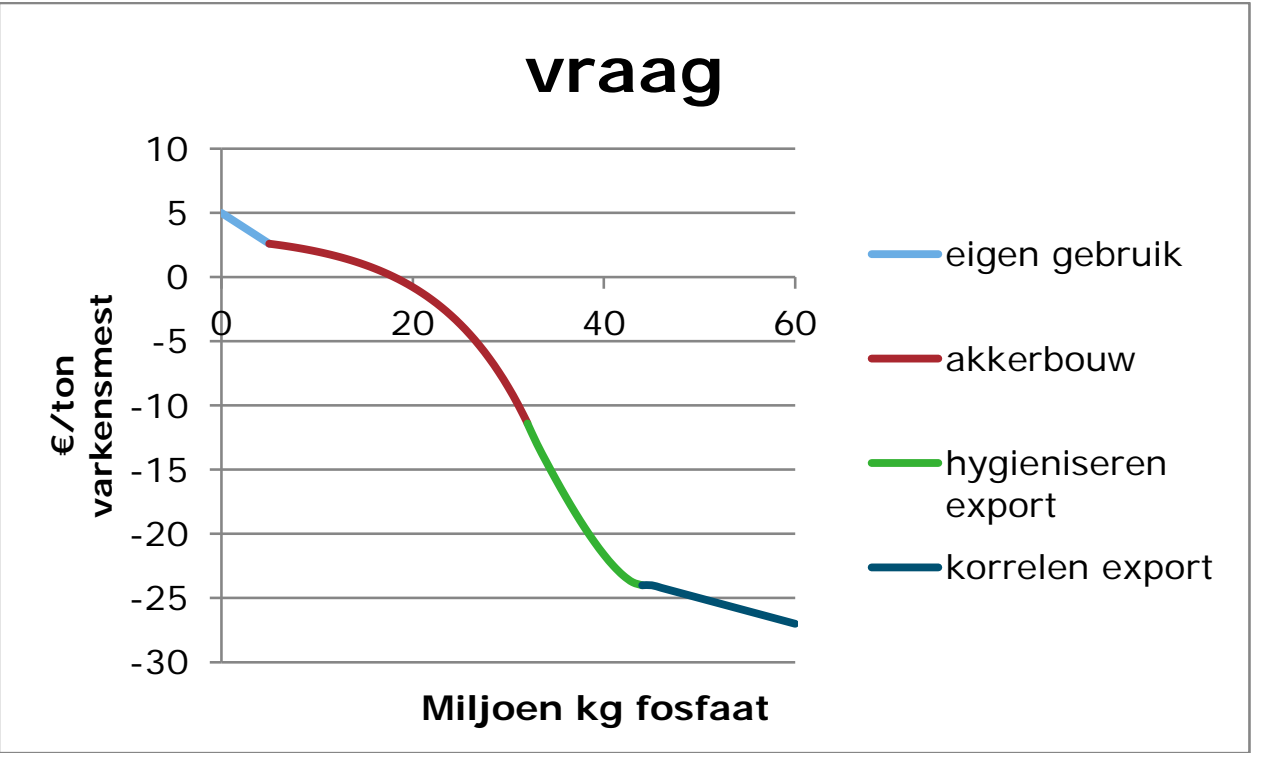

Figuur 2.8 Relatie vraag (onderverdeeld in deelmarkten) en aanbodprijs voor varkensmest in het zuidelijk zandgebied voor 2011

Bron: De Koeijer et al. (2013).

\section{Evenwichtsprijs}

De evenwichtsprijs wordt bepaald door vraag en aanbod

Het sleutelwoord binnen de economie is schaarste. Hoe meer vraag naar een schaars goed, hoe hoger de prijs. Als de vraag naar een schaars goed relatief groot is ten opzichte van het aanbod is de prijs voor dat goed relatief hoog. De markt van een schaars goed is het geheel van vraag en aanbod naar dat goed. De prijs voor het goed wordt bepaald door het punt waarbij het aanbod gelijk is aan de vraag. Op dat punt is de markt in evenwicht. Voor de mestmarkt gaat het om het evenwicht tussen aanbod van mest en vraag naar mest op de Nederlandse mestmarkt (figuur 2.9). De evenwichtsprijs kan omhoog door het verkleinen van het aanbod of door het vergroten van de vraag. Bij een verkleining van het aanbod, schuift de aanbodscurve naar links waardoor de vraag- en aanbodcurve elkaar snijden bij een hogere mestprijs. Bij een toename van de vraag verschuift de vraagcurve naar rechts waardoor vraag- en aanbodcurve elkaar eveneens snijden bij een hogere mestprijs.

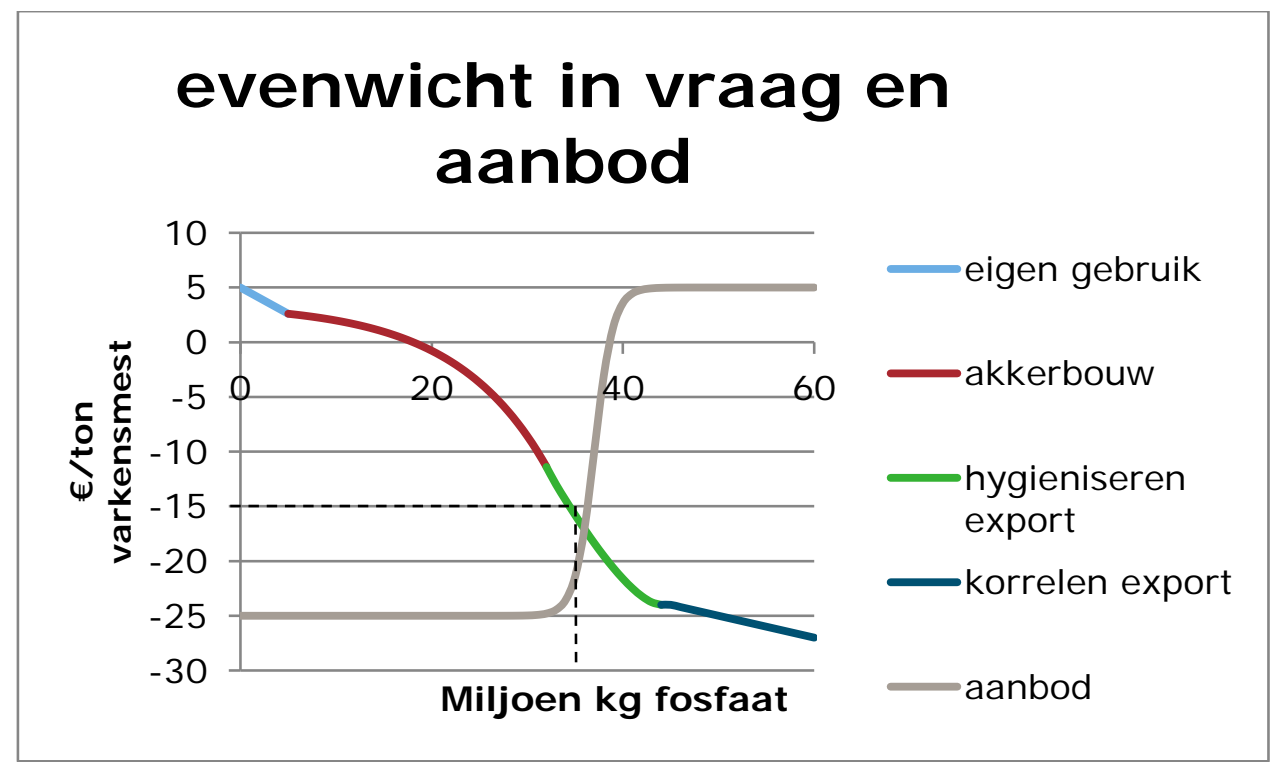

Figuur 2.9 De evenwichtsprijs voor de vraag en het aanbod van varkensmest in 2011 in het zuidelijk zandgebied

Bron: Monitoring mestmarkt 2011 en LEI, De Koeijer et al. (2013) in PBL (2013). 
Mestmarkt versus markt voor mestplaatsingsruimte

Nederlandse akkerbouwers kunnen meer voor de mest betalen dan ze nu doen aangezien de prijs van mest voor hen concurreert met die van kunstmest. Echter, de akkerbouwers hoeven deze prijs niet te betalen aangezien mest voor hen geen schaars goed is. Veehouders brengen het graag naar hen toe zolang dit goedkoper is dan andere alternatieven voor de afzet van mest.

Feitelijk is, sinds de jaren negentig, niet langer mest het schaarse goed op de mestmarkt maar is dat de plaatsingsruimte voor mest in de Nederlandse landbouw. Voor de veehouders concurreert de plaatsingsruimte voor mest in de akkerbouw met die van de kosten voor de afzet naar mestverwerkers en export. Daarom zijn zij bereid om de akkerbouwer te betalen voor het beschikbaar stellen van hun plaatsingsruimte waarbij de kosten voor die van mestverwerking veelal de bovengrens vormen. ${ }^{11} \mathrm{Op}$ de Nederlandse mestmarkt is dus niet zozeer sprake van een vraag naar mest door akkerbouwers maar naar een vraag naar plaatsingsruimte voor mest door veehouders.

Een akkerbouwer ${ }^{12}$ met plaatsingsruimte krijgt per hectare landbouwgrond het meest betaald als hij zoveel mogelijk kilogrammen dierlijke mest kan plaatsen. De hoeveelheid mest die een akkerbouwer kan plaatsen, wordt wettelijk begrensd door de gebruiksnormen. Veelal is de gebruiksnorm fosfaat het eerst beperkend. Dit betekent dat een akkerbouwer zoveel mogelijk mest met een zo laag mogelijk fosfaatgehalte zal willen plaatsen. Hierdoor is de prijs van mestsoorten met een laag fosfaatgehalte zoals rundveedrijfmest en de dunne fracties van gescheiden mest per gewichtseenheid minder negatief dan die van mestsoorten met hoge fosfaatgehalten zoals varkensdrijfmest en de dikke fracties van gescheiden mest.

Effect fraude op mestafzetprijs

Indien er op de huidige markt fraude is, wordt er minder mest daadwerkelijk regulier afgezet dan zou moeten. Dit betekent dat bij het wegvallen van de fraude het fysieke aanbod van mest op de mestmarkt zou toenemen. Hierdoor verschuift de aanbodcurve in figuur 2.9 naar rechts. Er ontstaat door deze verschuiving vervolgens een nieuwe evenwichtsprijs waar vraag en aanbod gelijk zijn aan elkaar. Dit nieuwe evenwicht wordt bij een verschuiving van de aanbodcurve naar rechts bij een lagere negatieve afzetprijs gevonden. Dit betekent dat bij afwezigheid van fraude ten opzichte van een situatie met fraude, veehouders meer moeten betalen voor de afzet van mest.

Geen effect op mestafzetprijs indien omvang verplichte mestverwerking kleiner is dan totale mestverwerking

Tot op heden (2017) is de omvang van de verplichte mestverwerking kleiner dan het nationale overschot. Dit betekent dat ook zonder verplichte mestverwerking de mest verwerkt moet worden als gevolg van gebrek aan andere afzetmogelijkheden. Hierdoor heeft de huidige verplichte mestverwerking geen effect op de mestafzetprijs, omdat de totale mestverwerking hoger is dan de verplichte. Door het vergroten van de huidige verplichte mestverwerkingspercentages kan de markt voor mest kunstmatig worden veranderd van een markt waarop het schaarse goed 'de plaatsingsruimte voor mest' is naar een markt waarop het schaarse goed 'mest' is.

In De Koeijer et al. (2013) is aangetoond hoe de realisatie van extra mestverwerkingscapaciteit de vraag naar mest en de bijbehorende prijs beïnvloedt. Door meer mestverwerkingscapaciteit vindt in feite een vergroting van de vraag naar mest plaats. De mestverwerkingsinstallatie 'vraagt' immers mest om te kunnen verwerken. Door deze extra vraag verschuift de vraagcurve in figuur 2.10 met de omvang van de extra vraag (mestverwerkingsplicht) naar rechts. Er ontstaat door deze extra vraag een nieuwe evenwichtsprijs. Zoals de figuur laat zien heeft de relatief kleine toename van de vraag met $6 \%$ (van circa 37 naar $39 \mathrm{mln}$. kg fosfaat), met als gevolg een verschuiving in het relatieve aandeel van verschillende vraagcomponenten, een relatief groot effect op de afzetprijs van $35 \%$ (van -17 naar - 11 euro/ton mest).

\footnotetext{
${ }^{11}$ Mestverwerking kan in sommige gevallen ook wel goedkoper zijn dan de afzet van dierlijke mest in de Nederlandse landbouw.

12 Voor het gemak wordt het begrip akkerbouwer gebruikt maar hieronder vallen ook veehouders die nog plaatsingsruimte voor mest over hebben.
} 
Het voorbeeld laat zien dat meer mestverwerking gunstig is voor de afzetprijs van mest op de reguliere markt. Echter, in de praktijk zal deze situatie alleen kunnen worden gerealiseerd als de mestverwerking verplicht wordt. Indien het niet verplicht is, zal een ondernemer zijn mest niet laten verwerken zolang de prijs hiervan hoger ligt dan die op de Nederlandse afzetmarkt. Daarbij geldt dat de omvang van de verplichte mestverwerking iets groter moet zijn dan de mestproductie minus de plaatsingsruimte voor mest in Nederland. Als dat niet het geval is, leidt de verplichte mestverwerking niet tot extra vraag en heeft die ook geen effect op de prijs.

Het mogelijke voordeel van de prijsverlaging als gevolg van een sterke verhoging van de verplichte mestverwerking (met daarbij een gedegen controlesysteem) is een kleinere fraudedruk omdat er voor frauderende ondernemers minder winst kan worden behaald. Los daarvan is het niet ondenkbaar dat een sterke verhoging van de verplichte mestverwerking netto tot lagere mestafzetkosten voor de veehouder leidt omdat de meerkosten van de veehouder voor de verplichte mestverwerking meer dan goed worden gemaakt door de lagere kosten voor de afzet van de overige mest. Door de extra mestverwerking kan ook een versnelling van de transitie naar een perspectiefvolle verwaarding van mest worden gerealiseerd. Hierdoor kan uiteindelijk de prikkel tot fraude volledig wegvallen. De precieze relatie tussen de omvang van verplichte mestverwerking, verwachte mestafzetprijs en de nettokosten/nettowinst voor de veehouder dient nader onderzocht te worden.

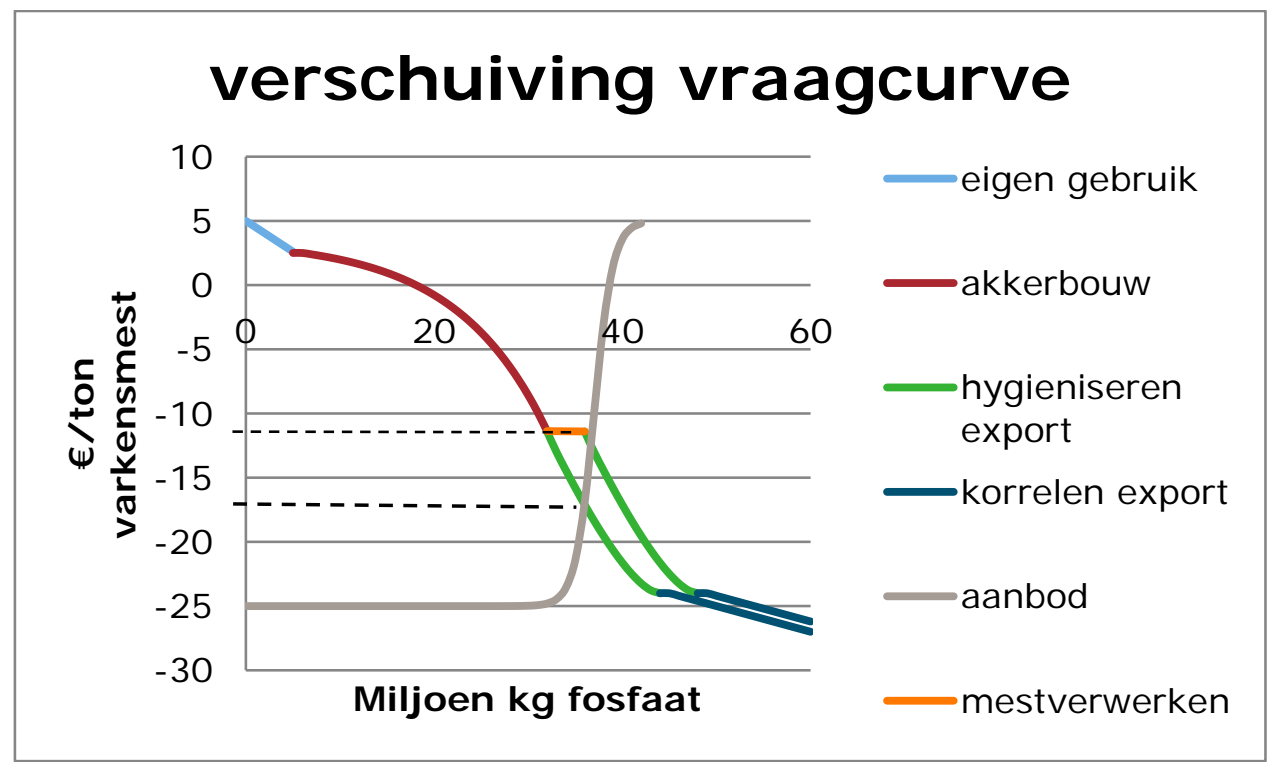

Figuur 2.10 Effect verschuiving van vraag naar varkensmest in het zuidelijk zandgebied door extra mestverwerkingscapaciteit

Bron: Monitoring mestmarkt (2011) en LEl in De Koeijer et al. (2013).

\subsection{Synthese}

De prijs voor de afzet van mest wordt bepaald door het duurste alternatief

Op de mestmarkt is het aanbod aan mest groter dan de vraag naar mest. Dit geldt allereerst voor de vraag vanuit de Nederlandse landbouw en overige vragers zoals hobbyboeren en natuur. Het geldt ook voor de vraag vanuit het buitenland en de vraag naar verwerkte mestproducten. Deze laatste vraag ontstaat alleen als de mestproducten goedkoper zijn dan het alternatief bestaande uit kunstmest. Dit betekent dat voor de afzet van mest zoveel betaald moet worden dat de mestproducten kunnen concurreren met kunstmest in het buitenland. Het betekent ook dat veehouders in hun zoektocht naar de goedkoopste afzetmogelijkheden bereid zijn om voor de afzet van mest prijzen te betalen die maximaal gelijk zijn aan het duurste alternatief. 
Doordat meer mest moet worden geëxporteerd, is het aanbod van gescheiden mest op de mestmarkt toegenomen.

De plaatsingsruimte in de Nederlandse landbouw is in de periode 2006-2015 met circa $20 \mathrm{mln}$. ton fosfaat afgenomen terwijl het aanbod min of meer gelijk bleef (figuur 2.1). Hierdoor moet in toenemende mate mest worden geëxporteerd. Omdat de plaatsingsruimte in de meest nabij gelegen gebieden in het buitenland is benut, moet meer mest over langere afstanden ( $>200 \mathrm{~km}$ ) worden getransporteerd. Voor het transport van mestkorrels is dat geen probleem maar het maken van mestkorrels is duur en de verwerkingscapaciteit is beperkt. Daarom wordt in toenemende mate mest gescheiden. Dit vergt minder investeringskosten en is daardoor minder risicogevoelig dan het maken van mestkorrels. Tegelijkertijd kan de relatief stikstofrijke dunne fractie in de Nederlandse landbouw worden afgezet waardoor ook bespaard kan worden op stikstofkunstmest.

In de periode 2006-2015 is de gehanteerde bemonsteringsmethode van de dikke fractie relatief fraudegevoelig.

Door de toegenomen export neemt het aandeel gescheiden mest toe. De bemonstering van de dikke fractie is echter fraudegevoelig doordat monsters van vaste mest makkelijker gemanipuleerd kunnen worden dan die van drijfmest. In combinatie met de relatief hoge mestafzetprijzen heeft dit tot een toename van de fraudedruk in de mestmarkt geleid. Wel wordt een groot deel van de transporten van dikke fractie door een beperkt aantal vervoerders verzorgd. Dit zou de controle hiervan kunnen vereenvoudigen.

In 2015 grotere kans op fraude vanwege een tekort aan mestverwerkingscapaciteit.

In 2015 waren, door een grotere mestproductie en een kleinere afzet op de binnenlandse markt, de afzetmogelijkheden van dierlijke mest op de mestmarkt vanwege een tekort aan mestverwerkings- en bewerkingscapaciteit te klein (figuur 2.2 en 2.1). Dit betekende dat er in 2015, gegeven de onzekerheden met betrekking tot de omvang van de mestproductie, sprake was van een relatief grote fraudedruk op de mestmarkt.

Vergroten omvang verplichte mestverwerking leidt tot lagere mestafzetprijzen.

De belangrijkste prikkel tot fraude zijn de hoge mestafzetprijzen waardoor fraude lucratief is. Om de prikkel tot fraude weg te nemen, zou fraude niet langer lucratief moeten zijn. De enige manier om dit te realiseren is door zorg te dragen voor lage mestafzetprijzen. Dit kan door het aanbod te verkleinen of de vraag te vergroten. Een vergroting van de vraag kan via voldoende verplichte mestverwerking worden gerealiseerd. Deze laatste stroom moet wel gecontroleerd. Extra mestverwerking zorgt ook voor een versnelling van de transitie naar een perspectiefvolle verwaarding van mest. Hierdoor kan uiteindelijk de fraudeprikkel volledig worden weggenomen. 


\section{Effect van de organisatie van de mesthandel op fraude en mestprijzen}

\subsection{Belangen actoren op de mestmarkt}

Beschrijving van de gezamenlijke en tegengestelde belangen van de actoren op de mestmarkt

Op de mestmarkt spelen de volgende actoren een rol:

1. De aanbieder van mest

Dit betreft de veehouders met een mestoverschot die hun mestoverschot op de mestmarkt aanbieden.

2. De intermediair

Dit betreft mesthandelaren, transporteurs en verwerkers die de overdracht van mest tussen de overige actoren op de mestmarkt realiseren door aan- en verkopen en via het transport.

3. De afnemer van mest

Dit betreft ondernemers in de Nederlandse en buitenlandse landbouw die mest afnemen ten behoeve van de bemesting van hun akkers. Voor wat betreft de buitenlandse afnemer moet mest ten behoeve van de export worden gehygiëniseerd en/of verwerkt ten behoeve van het transport.

De belangen van de actoren op de mestmarkt verschillen ten aanzien van de afzetprijs en de mineraleninhoud. Zo is de leverancier gebaat bij een lage mestafzetprijs, terwijl de afnemer gebaat is bij een hoge mestafzetprijs (figuur 3.1a).

Afzet naar Nederlandse landbouw relatief ongevoelig voor fraude door tegengesteld belang van veehouder en akkerbouwer

Ook voor de mineraleninhoud geldt dat er tegengestelde belangen zijn (figuur 3.1b). De organisatie van het mestbeleid binnen Nederland maakt dat zowel de veehouder (aanbieder van mest) als de akkerbouwer (afnemer van de mest) de hoeveelheden mest moet verantwoorden in zijn mestboekhouding. Als een veehouder of mesthandelaar minder mineralen levert dan wat op basis van de administratie geleverd zou moet worden, is dit nadelig voor de akkerbouwer. Hij heeft dan immers onvoldoende bemest om zijn gewassen goed te laten groeien, terwijl hij op papier wel voldoende mineralen uit mest heeft ontvangen. Dit kan tot opbrengstderving leiden. Als dit de akkerbouwer één keer is overkomen, zal hij daarna niet nog een keer mest afnemen van de betreffende veehouder en/of mesthandelaar die hem de mest had geleverd met minder mineralen dan op papier staat. Dit systeem maakt dat de kans op grootschalig frauderen met monsternames en hoeveelheden bij de reguliere afzet in de Nederlandse landbouw gering is op voorwaarde dat er geen 'zwarte' mest bij de export is ontstaan (zie vervolg van deze paragraaf).

Export is fraudegevoeliger vanwege afwezigheid tegengesteld belang

$\mathrm{Bij}$ de afzet van mest is over het algemeen sprake van tegengestelde belangen tussen de leverancier en de afnemer (figuur 3.1a en b). Echter, bij export ontbreekt dit tegengestelde belang omdat de buitenlandse afnemer geen mineralenboekhouding hoeft te verantwoorden (figuur 3.1b). Zo maakt het voor een Belgische afnemer niet uit of de in Nederland geproduceerde mest die naar België wordt geëxporteerd nu wel of niet geleverd wordt met minder mineralen dan op papier was gemeld. Dit komt doordat in België in die situaties met forfaits wordt gerekend. Dit betekent dat met name de export naar het buitenland een aangrijpingspunt voor fraude vormt. Een betere afstemming met omringende landen over gehaltes en hoeveelheden aan- en afgevoerde mest is dus nodig. In feite zou hetzelfde tegengestelde belang gecreëerd moeten worden tussen Nederlandse aanbieders van mest en afnemers in het buitenland als tussen Nederlandse aanbieders en - afnemers van mest. Dit zou mogelijk in het kader van het Europese mestbeleid kunnen worden opgepakt. 


\section{Belang mestafzetprijs per actor op de mestmarkt}

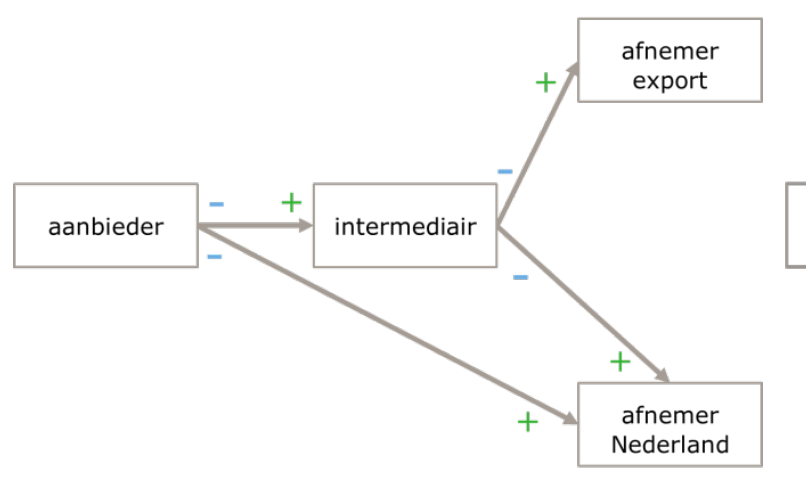

Belang inhoud mineralen per actor op de mestmarkt

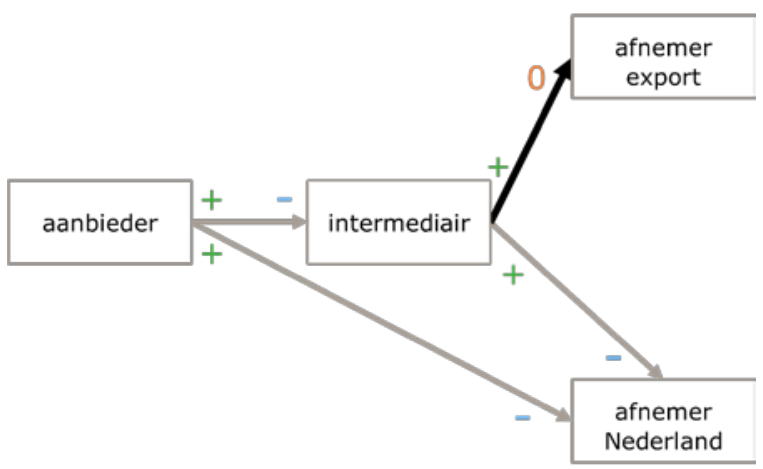

Figuur 3.1 A. Positief dan wel negatief belang bij een hogere mestafzetprijs en B. bij een hogere mineraleninhoud in de mest per onderscheiden actor op de mestmarkt

Effect 'zwarte' mest op de kans op fraude

Doordat bij export het tegengestelde belang tussen aanbieder en afnemer ontbreekt, kan op papier meer mest worden geëxporteerd dan in de praktijk. De zo ontstane 'zwarte' mest kan voor akkerbouwers aantrekkelijk zijn in het licht van de gebruiksnormen die de toegestane bemesting beperken. Om te voorkomen dat akkerbouwers frauderen met zwarte mest is het vooral van belang om het ontstaan van 'zwarte' mest tegen te gaan. Het creëren van een tegengesteld belang bij export kan hier een bijdrage aan leveren.

\subsection{Analyse aan- en afvoerstromen van mest in de mesthandel}

In de mesthandel wordt meer fosfaat afgevoerd dan aangevoerd

De intermediairs (bestaande uit mesthandelaren, transporteurs en verwerkers) zijn verantwoordelijk voor het transport van de mest van de aanbieder naar de afnemer van mest. Aanbieders kunnen zijn: veehouders en mestbe- en verwerkers. Afnemers zijn akkerbouwers en veehouders met plaatsingsruimte in Nederland, mestbe- en verwerkers en de landbouw in het buitenland. Bij de monitoring mestmarkt van de jaren 2009 en 2010 (Luesink et al., 2011) werd geconstateerd dat de aan- en afvoer van mest en mineralen bij intermediairs niet met elkaar in evenwicht zijn. Er werden over het algemeen meer mest en mineralen aangevoerd dan er werden afgevoerd. Dat kwam vooral voor bij fokvarkensdrijfmest, droge pluimveemest, slib van vleeskalverdrijfmest en rundveedrijfmest (Luesink et al., 2011).

Op basis van gegevens van RVO voor het jaar 2015 is nagegaan of dat in 2015 ook nog het geval is. In 2015 voeren de intermediairs circa 10\% meer mest en mineralen af dan aan. Voor stikstof is de totale aanvoer gelijk aan de totale afvoer (tabel 3.1). Daarbij is ook het totale gewicht aan mest gelijk gebleven (bijlage 2) maar is de gemiddelde fosfaatconcentratie van de afgevoerde mest toegenomen (bijlage 3).

Een analyse van de aan- en afvoer in gewichtseenheden en in hoeveelheden mineralen geeft aan dat de aangevoerde mest in grote mate wordt bewerkt en/of gemixt waardoor de aan- en afvoerbalans per mesttype niet te vergelijken is. Ook is geconstateerd dat de labelling van de mest niet altijd volledig de inhoud juist weergeeft, aangezien de totalen van de mest per diersoort onafhankelijk van de bewerking zouden moeten kloppen. Dit is niet het geval. Dit kan verklaard worden doordat mogelijk mest van verschillende diersoorten wordt gemixt en het mogelijk wordt gelabeld op basis van het belangrijkste mestbestanddeel. 
Door het mixen van mestsoorten is analyse van de aan- en afvoerstromen van mest bij vervoerders complex

Een voorbeeld van het mixen en daardoor onvolledig labellen, is het feit dat de afvoer van drijfmest in gewichtseenheden (zie bijlage 2) maar een klein beetje lager is dan de aanvoer. Omdat er wel drijfmest is gescheiden (er wordt namelijk meer dikke fractie afgevoerd dan aangevoerd (tabel 3.1 nr. 13 en 43) lijkt het er dus op dat de afvoer van dunne fractie van gescheiden mest door de vervoerders is gelabeld als drijfmest. Dat kan ook afgeleid worden uit de fosfaat- en stikstofgehalten van de drijfmest die aan- en afgevoerd wordt (bijlage 3). De fosfaatgehalten in de afgevoerde drijfmest zijn lager dan die in de aangevoerde mest; voor stikstof is dat juist andersom.

Wat verder opvalt, is dat de afvoer van mineralen en volume van vaste pluimveemestsoorten, vaste paardenmest en champost ongeveer het dubbele is van wat er is aangevoerd. Feitelijk is dat niet mogelijk. Ook hiervan kan mixen en verkeerd labellen een oorzaak zijn. Een andere verklaring kan zijn dat de extra afgevoerde hoeveelheid vaste pluimveemest afkomstig is uit voorraden van het voorgaande jaar. Dit zou ook kunnen verklaren dat er in totaal meer fosfaat wordt afgevoerd dan aangevoerd. Om te kunnen nagaan of dit daadwerkelijk het geval is, zou de analyse van de transporten naar en van vervoerders ook voor voorgaande jaren moeten worden uitgevoerd. Deze analyse viel buiten het bestek van dit onderzoek.

Ten slotte valt op dat de fosfaatgehalten in vaste mestsoorten verschillen bij aan- en afvoer (bijlage 1):

- Het fosfaatgehalte van de afgevoerde dikke fractie van gescheiden rundveemest is $50 \%$ hoger dan die in de aangevoerde dikke fractie.

- Bij vaste vleeskuikenmest is het fosfaatgehalte van de afgevoerde mest bijna $25 \%$ hoger dan die in de aangevoerde mest; bij stikstof is het juist andersom.

Dat de gehalten in de vaste mest per mestsoort niet gelijk zijn, kan het gevolg zijn van het mixen met mestsoorten met hogere gehaltes. De analyse van de totale aangevoerde en afgevoerde hoeveelheid mineralen laat echter zien dat er in totaal circa $10 \%$ meer fosfaat is afgevoerd dan aangevoerd.

Tabel 3.1 Aan- en afvoer van fosfaat en stikstof (in $1.000 \mathrm{~kg}$ ) in mest bij intermediairs in 2015 en de verhouding tussen aan- en afvoer naar mestnummer

\begin{tabular}{|c|c|c|c|c|c|c|}
\hline & \multicolumn{2}{|c|}{ Afvoer } & \multicolumn{2}{|c|}{ Aanvoer } & \multicolumn{2}{|c|}{ Aanvoer/ Afvoer } \\
\hline & Fosfaat & Stikstof & Fosfaat & Stikstof & Fosfaat & Stikstof \\
\hline 19 Rundvee-mest vleeskalveren, rosévlees & 49 & 99 & 117 & 273 & 2,4 & 2,7 \\
\hline 40 Varkens-vaste mest & 60 & 50 & 128 & 135 & 2,1 & 2,7 \\
\hline 10 Rundvee-vaste mest & 114 & 183 & 152 & 278 & 1,3 & 1,5 \\
\hline 17 Rundvee-bewerkte vleeskalverdrijfmest & 171 & 158 & 223 & 196 & 1,3 & 1,2 \\
\hline 116 Overige mestsoorten & 302 & 385 & 170 & 271 & 0,6 & 0,7 \\
\hline 76 Nertsen-drijfmest & 117 & 168 & 398 & 625 & 3,4 & 3,7 \\
\hline 25 Paarden-vaste mest & 325 & 564 & 190 & 354 & 0,6 & 0,6 \\
\hline 75 Nertsen-vaste mest & 336 & 154 & 386 & 180 & 1,1 & 1,2 \\
\hline 46 Varkensdrijfmest (op)fokvarkens inclusief biggen & 223 & 387 & 1.218 & 1.734 & 5,5 & 4,5 \\
\hline 13 Rundveekoek na mestscheiding & 768 & 934 & 698 & 1.232 & 0,9 & 1,3 \\
\hline 32 Kippenmestband & 1.039 & 1.056 & 445 & 529 & 0,4 & 0,5 \\
\hline 39 Vleeskuikens en parelhoenders, alle systemen & 831 & 1.125 & 849 & 1.656 & 1,0 & 1,5 \\
\hline 35 Kippenstrooisel (inclusief volière/scharrel) & 976 & 1.061 & 786 & 781 & 0,8 & 0,7 \\
\hline 43 Varkenskoek na mestscheiding & 4.269 & 2765 & 1.978 & 1.369 & 0,5 & 0,5 \\
\hline 50 Varkensdrijfmest vleesvarkens & 4.263 & 7012 & 5.790 & 9.123 & 1,4 & 1,3 \\
\hline Overig & 361 & 582 & 138 & 298 & 0,4 & 0,5 \\
\hline
\end{tabular}

Bron: RVO, bewerking Wageningen Economic Research. 
Twee belangrijke potentiële vormen van fraude betreffen het alleen administratief juist afzetten van mest en het manipuleren van monsters

RVO.nl onderscheidt bij intermediairs twee belangrijke mogelijkheden om te frauderen (Velthof et al., 2017). De eerste betreft het manipuleren van monsters en hoeveelheden, de tweede betreft het alleen administratief juist af zetten van mest maar dit in de praktijk niet uit voeren. De pakkans hierbij is erg klein doordat slechts $0,1 \%$ van de transporten fysiek worden gecontroleerd.

De per 1 oktober 2017 ingevoerde verplichte onafhankelijke monsterneming van de dikke fractie van gescheiden mest, is een belangrijke maatregel in de fraudeaanpak aangezien juist bij de bemonstering van vaste mest waaronder gescheiden dikke fractie veel mogelijkheden voor manipulatie zijn.

\subsection{Effect mesthandel op de mestprijs}

Door concurrentie binnen de mesthandel kan de afzetprijs van mest niet onnodig worden opgedreven De mesthandel vervoert mest van de mestaanbieders naar de mestafnemers. De mesthandel brengt hiervoor kosten in rekening voor: 1) het vervoer van de mest; 2) de bemonstering; en 3) eventuele opslag. Deze kosten zijn onafhankelijk van de prijs die veehouders betalen voor de afvoer van hun mest. De Koeijer et al. (2015) beschrijven dat de hogere mestafzetkosten per ton mest die veehouders in 2015 betalen ten opzichte van die in 2013 vrijwel direct ten goede komen aan de afnemers van de mest.

Bij een afzetprijs van gemiddeld 18 euro per ton varkensmest, distributietarieven over korte afstand van 4 euro (Broens et al., 2012) en over lange afstand (gemiddeld $100 \mathrm{~km}$ ) van gemiddeld 10 euro per ton (Horne et al., 2009), komt het er globaal op neer dat een akkerbouwer in 2015 in of nabij overschotgebieden 14 euro per ton varkensdrijfmest toe krijgt en een wat verder weggelegen akkerbouwer gemiddeld 8 euro per ton varkensdrijfmest.

Bij een afzetprijs van gemiddeld 11 euro per ton voor rundveedrijfmest, komt het er globaal op neer dat een akkerbouwer in 2015 in of nabij overschotgebieden 7 euro per ton rundveedrijfmest toe krijgt en een akkerbouwer wat verder weg gemiddeld 1 euro per ton rundveedrijfmest.

De kosten voor vervoer zijn min of meer onafhankelijk van de transporteur. In Nederland zijn er circa 800 mesthandelaren/transporteurs. Zij kunnen niet zelf de prijs bepalen maar zitten vanwege de onderlinge concurrentie eerder beneden dan boven de kostprijs. Gezien deze concurrentie mag aangenomen worden dat de mesttransportcapaciteit geen beperkende factor is waardoor mogelijk hogere prijzen dan de kostprijs gevraagd zouden kunnen worden.

\subsection{Fraudegevoelige prikkels in de mesthandel}

Een hoge mestafzetprijs maakt fraude lucratief

Bij hoge mestafzetprijzen is fraude lucratief in de mesthandel. Indien een mesthandelaar de mest minder ver vervoert dan is aangegeven op de VDM, bespaart hij zowel op de transportkosten als op de kosten voor de afzet van mest. Fraude kan zeer aantrekkelijk zijn, omdat het hierbij om grote bedragen kan gaan (zie paragraaf 4.2).

Fraude in mesthandel resulteert in ongelijke concurrentieverhoudingen binnen de mesthandel Als er frauderende collega's zijn, is het voor andere intermediair heel moeilijk om hiermee te concurreren. Indien een frauderende collega op een niet-reguliere wijze mest afzet, hoeft hij voor de afzet en/of het transport van de mest minder te betalen. Deze winst kan hij deels toekennen aan de aanbieder van mest, die daardoor tegen geringere afzetkosten zijn mest kwijt kan.

Als fraude veel voorkomt, maakt dit de druk voor niet-frauderende collega-intermediairs groot. De concurrentiepositie van niet-frauderende collega's wordt ondermijnd doordat frauderende collega's hun diensten onder de reguliere kostprijs kunnen aanbieden en zo een groter marktaandeel kunnen verwerven. 


\subsection{Synthese}

Door het mixen en mengen van de aangevoerde mestproducten is analyse van de meststromen in de mesthandel erg complex. Overall is de totale aan- en afvoer in volume- en stikstofeenheden gelijk maar van fosfaat werd in 2015 10\% meer afgevoerd dan aangevoerd (tabel 3.1). Een verklaring hiervan is niet beschikbaar. Hiervoor is een meer intensieve analyse van de aan- en afgevoerde mest en mestproducten op bedrijfsniveau over meerdere jaren nodig.

Het effect van de mesthandel op de mestprijs bestaat uit een toeslag gebaseerd op de kosten voor met name de distributie van mest die vooral afhankelijk is van de transportkilometers. De indruk bestaat dat deze kosten vanwege de onderlinge concurrentie eerder onder dan boven de kostprijs liggen.

De fraudedruk is in de mesthandel toegenomen vanwege de relatief hoge mestafzetprijzen waardoor fraude lucratiever is. Relatief fraudegevoelige aspecten van de mesthandel betreffen:

1. de toegenomen omvang van transporten van dikke fractie waarvan de bemonstering relatief fraudegevoelig is.

2. de toegenomen export die fraudegevoeliger is dan afzet in de Nederlandse landbouw doordat bij export minder sprake is van tegengestelde belangen. Een bijkomend effect is het ontstaan van 'zwarte' mest die weer tot verdere fraude leidt bij de afzet daarvan.

3. de kleine pakkans bij fraude (0,1\% van de transporten wordt fysiek gecontroleerd (Velthof et al., 2017) doordat de controle zich veelal richt op de administratie en niet zozeer op de fysieke stromen. En door het ontbreken van juridische handvatten om mestpartijen met onwaarschijnlijke mineralengehaltes niet te accepteren.

Fraude bevoordeelt de fraudeur zelf maar heeft indirect een negatief effect op de concurrentiepositie van niet-frauderende collega's als fraudeurs hun diensten onder de reguliere kostprijs kunnen aanbieden en zo ook een groter marktaandeel kunnen verwerven. 


\section{$4 \quad$ Resultaten interviews en workshop}

In dit hoofdstuk wordt ingegaan op de, in interviews en in een workshop genoemde, mogelijkheden om te frauderen en prikkels die fraude kunnen bevorderen. De gepresenteerde bevindingen zijn grotendeels gebaseerd op zestien interviews met betrokken actoren (drie met belangenorganisaties, vijf met mesttransporteurs, drie met akkerbouwers en vijf met veehouders) en een workshop met beleidsmakers van het ministerie van Economische Zaken en een deel van de genoemde actoren. Om de anonimiteit te waarborgen worden de namen van de geïnterviewden en deelnemers aan de workshop niet vermeld.

\subsection{Mogelijkheden om te frauderen}

Met name het fysieke transport bij export en de bemonstering van dikke fractie worden fraudegevoelig genoemd

In de interviews en de workshop werd door bijna iedereen mestscheiding genoemd waarbij vooral de bemonstering van de dikke fractie belangrijke mogelijkheden biedt om te frauderen. Daarnaast werd door meerdere geïnterviewden ook gewezen op de export van mest die wel administratief klopt maar in de praktijk niet wordt geëxporteerd. Ook wezen verschillende geïnterviewden op het manipuleren van het gewicht via de weegbrug. Een uitgebreid overzicht van de genoemde mogelijkheden voor fraude is weergegeven in bijlage 4.

Interviews: fraude vindt vooral plaats bij het ontbreken van tegengesteld belang Bij fraude zijn verschillende partijen betrokken. Eén van de geïnterviewden omschreef het zo:

‘Bij fraude heb je te maken met verschillende partijen, ieder met zijn eigen belang. De veehouder hikt aan tegen de hoge kosten van de afzet van zijn mest; de akkerbouwer kan vaak best wat meer mineralen gebruiken dan de normen aangeven en ook voor een malafide transporteur is er veel geld te verdienen. Ik zou niet kunnen zeggen wie daarbij het initiatief neemt.'

Volgens de geïnterviewden vindt fraude vooral plaats als er geen tegengesteld belang is tussen de verschillende betrokken partijen. Zo is er bij de afzet van mest middels een VDM bij een akkerbouwer in Nederland wel sprake van een tegengesteld belang. Voor de veehouder met een mestoverschot is het van belang om op papier zo veel mogelijk mineralen van zijn bedrijf af te voeren. Echter, als een akkerbouwer op papier meer mineralen krijgt dan in werkelijkheid, resulteert dit in één van de volgende twee situaties:

1. Hij bemest volgens de mestboekhouding meer dan de gebruiksnorm. Hierdoor loopt hij grote kans een boete te krijgen voor de overschrijding van de gebruiksnormen.

2. Zijn gewassen krijgen minder mineralen toegediend dan volgens de landbouwkundige adviesgift gewenst is. Hierdoor krijgt hij te maken met opbrengstderving.

Beide situaties zijn economisch ongewenst voor de akkerbouwer. Hij zal er dan ook goed op letten dat hij de hoeveelheid mineralen krijgt zoals die op de VDM's staan vermeld. Op het moment dat het een keer niet klopt zal de betreffende akkerbouwer overstappen naar een leverancier van mest waarin hij het vertrouwen heeft dat die de hoeveelheid mineralen levert zoals op de VDM is vermeld. Eén van de geïnterviewden (een akkerbouwer) gaf aan dat hij eenmaal mest geleverd had gekregen met veel lagere gehalten dan er op de VDM stond vermeld en dat hierdoor zijn gewas toen veel minder mineralen kreeg dan nodig was met als gevolg lagere opbrengsten. Zijn reactie was: 'Dat eens maar nooit meer.' Hij is toen overgestapt naar een leverancier waarbij hij wel vertrouwt dat de gehalten die op de VDM's staan vermeld, overeenkomen met de werkelijkheid. Dat hij daarbij dan 1 à 2 euro minder toe krijgt per ton geleverde mest heeft hij ervoor over. 
Mest scheiden is vooral lucratief bij fraude volgens geïnterviewden

Op één na gaven alle geïnterviewde transporteurs aan dat scheiding van varkensdrijfmest en rundveedrijfmest ten behoeve van de mestafzet niet uit kan binnen de regelgeving. Zij gaven aan dat mestscheiding alleen lucratief is wanneer daarbij gefraudeerd wordt. Twee respondenten gaven aan dat ze wel over een mestscheidingsinstallatie beschikten maar deze niet gebruikten, omdat het financieel niet uit kan wanneer je het volgens de regels doet. Vrijwel alle respondenten gaven aan dat er bij mestscheiding, wanneer de dikke fractie wordt geëxporteerd, zowel gefraudeerd wordt met de gehalten in de dikke fractie als het gewicht van de dikke fractie. Ook uit onderzoek van Wageningen Economic Research (De Koeijer et al., 2017) bleek dat mestscheiding, waarbij de dikke fractie zonder verdere verwerking in het buitenland wordt afgezet, financieel niet uit kon bij de gehanteerde uitgangspunten.

De respondenten gaven de volgende voorbeelden aan van financieel gewin door fraude en om welke hoeveelheden het kan gaan:

‘Een bedrijf heeft 1.000 ton mest die afgevoerd moet worden met daarin $4.000 \mathrm{~kg}$ fosfaat. De intermediair regelt dat de mest "gescheiden" wordt. Hiervan wordt in werkelijkheid 100 ton dikke fractie geëxporteerd, terwijl volgens de VDM's echter 250 ton wordt geëxporteerd.

Daarnaast is het fosfaatgehalte in de dikke fractie volgens de VDM's zo hoog dat alle fosfaat van de oorspronkelijke 1.000 ton mest $(4.000 \mathrm{~kg})$ met de vermelde hoeveelheid van 250 ton dikke fractie wordt geëxporteerd. Op deze wijze is op papier het hele overschot van $4.000 \mathrm{~kg}$ fosfaat geëxporteerd met 250 ton dikke fractie, terwijl er in werkelijkheid maar 100 ton dikke fractie is geëxporteerd.'

'De GPS sensor is zo afgesteld dat wanneer er 7,5 ton geladen is het GPS signaal van laden wordt verzonden. Vervolgens rijdt men naar België (Antwerpen), daar wordt een vrachtbrief aangemaakt dat er 35 ton is geleverd. Dit gewicht gaat naar EZ en komt op de VDM te staan. In werkelijkheid wordt er 7,5 ton dikke fractie afgeleverd met een gehalte van $5 \mathrm{~kg}$ fosfaat per ton $=37,5 \mathrm{~kg}$ fosfaat. Maar op papier staat 35 ton geleverd met een forfaitair gehalte van 9,8 kg fosfaat en dat is $343 \mathrm{~kg}$ fosfaat.'

In het eerste voorbeeld dat door een geïnterviewde werd geschetst maar dat ook werd ondersteund door verhalen van andere geïnterviewden is dus op papier tien maal zoveel mest geëxporteerd dan in werkelijkheid. Ook in het tweede voorbeeld, dat eveneens door meer respondenten werd ondersteund, wordt op papier circa tien maal zo veel geëxporteerd dan in de praktijk.

Hoe deze door de geïnterviewden gegeven voorbeelden economisch kunnen uitpakken voor de veehouder en de transporteur is in het bijgaande rekenvoorbeeld uitgewerkt voor de situatie zonder en met fraude. De in het rekenvoorbeeld vermelde prijzen en bedragen zijn gebaseerd op aannames aangezien de werkelijke prijzen niet exact bekend zijn. 
Tekstbox 4.1 Voorbeeldcase waarin de potentiële winsten voor de betrokken partijen worden getoond voor een door een geïnterviewde beschreven voorbeeld van fraude

\section{Rekenvoorbeeld: Zonder fraude}

De prijs af boerderij wordt zonder fraude geschat op 17 euro per ton mest. De kosten voor de veehouder voor de afzet van 1.000 ton mest bedragen dan 17.000 euro.

De mesthandelaar krijgt $17 * 1.000=17.000$ euro betaald. De kosten voor de mesthandelaar voor de afzet van deze 1.000 ton mest bedragen: 1) 1.000 ton mest scheiden a 3,5 euro per ton; 2) 250 ton dikke fractie exporteren à 20 euro per ton; en 3) 750 ton dunne fractie afzetten voor een geschatte prijs van 5 euro per ton. Vervolgens ontvangt de afnemer ongeveer 6,50 euro per ton dunne fractie voor het beschikbaar stellen van plaatsingsruimte wanneer hij deze legaal afneemt. De mesthandelaar heeft dan 17.000 euro ontvangen en 17.125 euro aan kosten $(3.500+5.000+3.750+4.875)$ gemaakt voor de afzet hiervan. Dat betekent dat de mesthandelaar volgens dit voorbeeld geen winst maakt en min of meer tegen kostprijs werkt.

\section{Rekenvoorbeeld: Met fraude}

Bij fraude wordt de prijs af boerderij geschat op 14 euro per ton voor de veehouder. De kosten voor de veehouder voor de afzet van 1.000 ton mest bedragen in deze situatie 14.000 euro. Bij fraude is de veehouder dus 3.000 euro goedkoper uit.

De mesthandelaar krijgt $14 * 1.000=14.000$ euro betaald. De kosten voor de verdere afzet hiervan bedragen naar schatting: 1) 400 ton mest gescheiden a 3,50 euro per ton, 2) 100 ton dikke fractie geëxporteerd a 20 euro per ton en 3) 900 ton 'zwarte' mest in de regio afgezet a 5 euro per ton en er hoeft niet betaald te worden voor de plaatsingsruimte bij de afzet van deze 'zwarte' mest. De kosten voor de mesthandelaar zijn in dit voorbeeld 7.900 euro $(1.400+2.000+4.500+0)$. Zijn winst bedraagt in dit voorbeeld dan 6.100 euro mest ( 14.000 euro ontvangen min 7.900 euro gemaakte kosten).

Met de invoering van de onafhankelijke bemonstering van gescheiden dikke fractie met ingang van 1 oktober 2017 is een deel van de in het rekenvoorbeeld geschetste problematiek aangepakt. Maar het probleem dat bij export de totale hoeveelheid geëxporteerde mest minder is dan die op papier is aangegeven, is daarmee nog niet aangepakt.

Op basis van de gegeven voorbeelden kan bij mest die als dikke fractie wordt geëxporteerd fors worden gefraudeerd. Gegeven de op de VDM's vermelde hoeveelheden fosfaat, is het niet onmogelijk dat ondanks de invoering van de onafhankelijke bemonstering van gescheiden dikke fractie de op papier geëxporteerde hoeveelheid fosfaat in de dikke fractie van gescheiden mest enkele malen groter is dan de werkelijke hoeveelheid.

De mest die als gevolg van de fraude niet wordt geëxporteerd, wordt als 'zwarte' mest illegaal in de Nederlandse landbouw afgezet.

\subsection{Prikkels die fraude in de hand kunnen werken}

De belangrijkste prikkels die genoemd zijn, betreffen de hoge mestprijzen en de geringe pakkans De belangrijkste prikkels om te frauderen die tijdens de interviews en de workshop naar voren kwamen, betreffen in grote lijnen (zie bijlage 4 voor meer details):

- de hoge mestprijs waardoor fraude lucratief is

- de geringe pakkans waardoor je, als de administratie maar klopt, als fraudeur weinig problemen hoeft te verwachten

- gebruiksnormen die te laag zijn waardoor het accepteren van 'zwarte' mest aantrekkelijk is

- spreiding in gehaltemetingen en/of te hoge forfaits die maken dat een veehouder soms creatief moet boekhouden om de mestboekhouding kloppend te krijgen. NB: dit geldt voor alle veehouders dus ook voor hen die te goeder trouw zijn.

In de jaren negentig is onderzocht (Hoeksma et al., 1996) dat laboratoria tot $15 \%$ onnauwkeurig zijn bij het bepalen van het gehalte in een partij mest. Dit is tot op heden de praktijk. Voor de mestmarkt is dit overall geen probleem want de afwijking kan zowel naar boven als naar beneden zijn. Echter, op bedrijfsniveau is deze $15 \%$ onnauwkeurigheid wel een groot probleem bij het rondkrijgen van de 
mestboekhouding. Een ondernemer is gedwongen tot creatief boekhouden. Dit levert veel chagrijn op als een veehouder bij een te lage meting te veel eigen mest moet afvoeren en hij zijn eigen gewas niet goed kan voeden. Om het land goed te kunnen bemesten is het belangrijk om te weten hoe de samenstelling van de mest precies is. $\mathrm{Nu}$ is de eigen grond het sluitstuk om de mestboekhouding rond te krijgen terwijl het goed bemesten van de eigen grond juist deel zou moeten uitmaken van het primaire proces. Een oplossing is om te rekenen met forfaits. Dit heeft echter ook nadelen, met name als mest lagere gehaltes heeft dan volgens het forfait zou moeten; veehouders mogen dan minder mest afvoeren dan op basis van de werkelijke samenstelling van de mest zou kunnen.

\subsection{Hoe vaak treedt fraude in de mesthandel op?}

Fraude komt veel voor volgens geïnterviewden.

Volgens de interviews komt fraude relatief veel voor en spelen eigenlijk alle betrokken partijen, dus zowel de veehouder als de intermediair/mesttransporteur, de mestscheider en de afnemer een rol bij fraude. Volgens de geïnterviewden zou in Zuid-Nederland mogelijk bij de helft van het totaal aantal transporten van mest een vorm van fraude plaatsvinden, in Midden-Nederland mogelijk bij een kwart en in West-Nederland mogelijk bij een achtste. Daarbij gaven ze aan dat 'iedereen' wel mensen kent die frauderen met mest.

Onderstaande fragmenten uit de interviews illustreren dit:

'De fraude frustreert enorm. Die bedrijven in de mesthandel groeien als kool. In de mestmarkt domineert de fraude. Als dit niet gestopt wordt, haakt de rest van de mesthandel af of doet mee. Als dit zo doorgaat blijven er geen goede meer over. Tien jaar geleden was er nog geen enkele rotte appel, tegenwoordig is het de normaalste gang van zaken.'

‘Het frauderen gebeurt massaal, naar schatting bij meer dan de helft van de intermediairs en bij ongeveer de helft van de mest in volume is er fraude en het wordt steeds erger. De mate waarin gefraudeerd wordt, verschilt.'

'De fraude breidt zich als een olievlek van het zuiden naar het noorden uit. Boeren horen van elkaar bij wie ze de mest het goedkoopst kwijt kunnen. Fraudeurs gaan ook langs bij de veehouders om klanten te werven.'

Tegelijkertijd geven de interviews ook aan dat volgens de geïnterviewden bij de meerderheid van de transporten geen sprake is van fraude. Als er fraude is, kan het volgens de geïnterviewden gaan om alle mogelijke vormen van fraude. Dat wil zeggen: van het niet juist labelen van de mestsoort, zoals bijvoorbeeld het labelen van vleeskalverendrijfmest als rundveemest zodat het binnen de derogatie kan worden aangewend, tot het transporteren van vrachten mest waar geen VDM voor is opgemaakt. Omdat op basis van de interviews niet is na te gaan welke vormen van fraude het betreft, kan daarom op basis van de interviews niet worden vastgesteld hoeveel stikstof en fosfaat door fraude buiten de mestboekhouding om in Nederland wordt afgezet. Ook was het niet mogelijk om de in de interviews genoemde percentages te checken.

\section{$4.4 \quad$ Synthese}

Fraude komt volgens de geïnterviewden met name voor bij de bemonstering van dikke fractie en bij export

Conform de theoretische analyse noemen de geïnterviewden de export als belangrijkste afzetkanaal waarbij fraude plaatsvindt. Dit komt doordat bij export een goed controlesysteem ontbreekt. Een belangrijke rol daarbij speelt ook het feit dat er bij transporten naar het buitenland geen tegengesteld belang is tussen de aanbieder en de afnemer waardoor ze er geen belang bij hebben om elkaar te controleren (zie paragraaf 3.1). 
De belangrijkste probleemgebieden waarbij fraude mogelijk is, betreffen in grote lijnen:

- de bemonstering van mest, waarbij vooral de bemonstering van dikke fractie zeer fraudegevoelig is. Dit probleem is met de invoering van de onafhankelijke bemonstering van dikke fractie van gescheiden mest in oktober 2017 aangepakt.

- de fysieke mestafvoer. Bij fraude hoeft een groot deel van de mest niet daadwerkelijk te worden afgevoerd maar alleen op papier.

De mest die als gevolg van de fraude niet wordt geëxporteerd, veroorzaakt nieuwe fraude doordat deze als 'zwarte' mest illegaal in de Nederlandse landbouw wordt afgezet.

Volgens de geïnterviewden zijn de hoge mestafzetprijzen en de te laag geachte gebruiksnormen de belangrijkste prikkels voor fraude

Conform de theoretische analyse noemden de geïnterviewden met name de hoge mestafzetprijzen waardoor fraude lucratief is. Daarnaast was ten tijde van de interviews het controlesysteem voor de transporten van vaste mest (nog) niet waterdicht maar is dit inmiddels met de invoering van de onafhankelijke bemonstering van dikke fractie van gescheiden mest sterk verbeterd.

Veelgenoemde prikkels waren ook de gebruiksnormen die men te laag vond waardoor ondernemers gevoelig zijn voor het accepteren van 'zwarte' mest en de spreiding in gehaltemetingen. Door deze spreiding in gehaltemetingen kunnen goedwillende ondernemers worden gedwongen tot frauduleuze administratie om de mestboekhouding kloppend te krijgen.

Fraude leidt tot grotere fraudedruk door concurrentievervalsing

Door de grote concurrentie tussen de mesttransporteurs worden de diensten van de mesthandel onder de kostprijs aangeboden. Voor frauderende handelaren is dit als gevolg van hun lagere kosten makkelijker. Hierdoor kunnen zij makkelijker concurreren, waardoor de druk tot fraude toeneemt bij bonafide mesthandelaren. 


\section{Oplossingen om fraudedruk te verminderen}

In dit hoofdstuk worden aan de hand van de in hoofdstuk 4 genoemde problemen de genoemde oplossingen gepresenteerd en bediscussieerd. De oplossingen in paragraaf 5.1 zijn grotendeels gebaseerd op zestien interviews met betrokken actoren (drie met belangenorganisaties, vijf met mesttransporteurs, drie met akkerbouwers en vijf met veehouders) en een gezamenlijke workshop met beleidsmakers van het ministerie van Economische Zaken en een deel van de genoemde actoren. Een overzicht van genoemde oplossingen is opgenomen in bijlage 4. Om de anonimiteit te waarborgen zijn de namen van de geïnterviewden en deelnemers aan de workshop niet vermeld. Paragraaf 5.2 bevat een uitwerking van een mogelijke oplossing gebaseerd op ingrijpen in de vraag- en het aanbod op de mestmarkt.

\subsection{Potentiële oplossingen en reflectie op haalbaarheid}

Het verlagen van de mestafzetprijs om prikkel tot fraude te verminderen

Allereerst zou de prikkel tot fraude als gevolg van hoge mestafzetprijzen aangepakt kunnen worden door de mestprijs te verlagen. Dit zou kunnen door meer aandacht voor 1 ) de verwaarding van mest en de acceptatie van mineralenconcentraten en/of dunne fractie als kunstmest, 2) door het aanbod te verminderen door het aantal dieren te verminderen, 3) de plaatsingsruimte in Nederland te vergroten door meer landbouwgrond beschikbaar te hebben en 4) door het creëren van een kunstmatige krapte op de mestmarkt. Daarnaast zou de prikkel weggenomen kunnen worden door het collectief heffen van mestafzetkosten en het verhandelen van de mest in een soort staatsbedrijf conform het systeem van bijvoorbeeld het ophalen en verwerken van afval.

Reflectie

Ad 1) Ten aanzien van de verwaarding van mest geldt dat dit een ideale oplossing is, maar ook dat deze oplossing de komende jaren nog niet in zicht is.

Ad 2) Het aanbod verkleinen is voor veehouders bedrijfseconomisch aantrekkelijker dan mestverwerking. Als dat niet zo zou zijn, zouden zij zelf namelijk al het besluit hebben genomen om minder dieren te houden.

Het kan wel zo zijn dat vanuit macro-economisch oogpunt het verminderen van het aantal dieren aantrekkelijk is doordat de vrijkomende productiefactoren zoals arbeid elders op de arbeidsmarkt meer toegevoegde waarde kunnen genereren. Echter, om een uitspraak te kunnen doen of dit mogelijk het geval is, is nader onderzoek nodig.

Ad 3) De plaatsingsruimte vergroten, betekent of minder ruimte voor natuur of hogere gebruiksnormen en dus negatieve impact op het milieu en is daarom geen gewenste oplossing.

Ad 4) Het creëren van krapte op de binnenlandse markt kan door zorg te dragen voor meer mestverwerking. Dit kan via verplichte mestverwerking zodat meer mest wordt verwerkt dan strikt noodzakelijk is waardoor er krapte op de binnenlandse mestmarkt ontstaat. Deze oplossing vergt een uitbreiding van de huidige mestverwerkingscapaciteit maar kan een kansrijke optie zijn aangezien dit relatief snel kan worden doorgevoerd. Door krapte op de binnenlandse markt worden de mestafzetprijzen van mest aanzienlijk lager. Dat een aanzienlijke vergroting van de mestverwerking effect kan hebben op de mestafzetprijzen werd tussen 2006 en 2010 gerealiseerd met het van start gaan van de BMC in Moerdijk in 2008 voor de verwerking van pluimveemest. In 2006 en 2007 bedroeg de afzetprijs van pluimveemest circa 30 euro. De meerjarige afzetcontracten voor pluimveemest naar de BMC bedroegen 15 euro per ton. Vervolgens nam vanaf 2008 de afzetprijs voor pluimveemest af tot circa 10 euro per ton. De gecontracteerde mestafzet kan daarbij vergeleken worden met de verplichte mestafzet die duurder is dan de reguliere mestafzet maar als gevolg van de 
verplichte mestafzet daalt de prijs van de reguliere mestafzet. De controle kan zich in deze situatie concentreren op de stromen die naar de mestverwerking gaan. Een verdere uitwerking is de optie van een statiegeldregeling voor mineralen in aangekocht veevoer. Hierbij kan de mestverwerkingsplicht van de veehouder naar de veevoerleverancier worden verlegd. Dit kan voordelen hebben doordat de veevoerfabrikanten efficiënter de mestverwerking kunnen organiseren. Voor de overheid heeft het als voordeel dat de controle op de afzet van mest kan worden geconcentreerd op de mestafzet van de veevoerfabrikanten.

Ook het werken met een systeem van ophalen en verwerken van afval is een optie waarbij de controle grotendeels kan worden beperkt tot de mestophaaldiensten maar dit vergt een aanmerkelijk grotere transitie.

Het controlesysteem van het fysieke transport verbeteren met foto's van de vracht Een genoemde technische oplossing die het controlesysteem kan verbeteren met betrekking tot de fysieke mestafvoer is het toevoegen van een digitale foto van de vracht mest bij laden en lossen. Dit betekent extra inspanning voor de controleurs maar deze foto's zouden prima via de computer vergeleken kunnen worden.

Reflectie

Ook foto's bieden veel ruimte voor manipulatie dus het is de vraag of dit een solide oplossing is.

Het gebruik van forfaitaire gehaltes

Om problemen met de bemonstering te voorkomen, is genoemd dat met forfaitaire gehaltes gewerkt zou kunnen worden.

Reflectie

Deze oplossing heeft nadelen omdat een akkerbouwer op basis van de forfaitaire norm onvoldoende bemestingsmogelijkheden heeft als hij over mest beschikt met lagere gehaltes dan de forfaitaire norm. Andersom moet een veehouder mogelijk meer mest afvoeren dan hij op basis van de werkelijke mineraleninhoud zou hoeven te doen, waardoor ook hij met zijn bemestingswaarde in de problemen komt.

Het controlesysteem vergt wetgeving om ongeloofwaardige gehaltes in de mest aan te pakken. In de interviews werd gepleit voor meer en effectievere controles door RVO. Deze kan alerter zijn op onmogelijke mineralengehaltes in de mest.

Reflectie

Een probleem is dat over de toegestane gehaltes in de mest niets in de wet staat. Zonder wetgeving over wat wel en niet toegestane gehaltes zijn, kan een rechter geen veroordeling uitspreken.

Controles vooral richten op de grote fraudeurs

De controles zouden zich meer moeten richten op actoren die verdacht worden van omvangrijke fraude.

Reflectie

De controles kunnen zo effectiever worden ingezet. Het is noodzakelijk dat de controleurs hiervoor de juiste tools hebben zoals bijvoorbeeld het werken met klokkenluiders, het opstellen van risicoprofielen en het gerichter controleren en dossiers opbouwen om bewijslast rond te krijgen.

Afstemming met buitenland noodzakelijk voor controle van de export

Uit de workshop en de interviews kwam naar voren dat fraude vooral optreedt bij de export van dikke fractie, omdat de controlesystemen in Nederland niet zijn afgestemd met die in het buitenland.

Reflectie

Afstemming met het buitenland is dus wenselijk. Dit zou mogelijk in Europees verband in het kader van gezamenlijk mestbeleid kunnen worden opgepakt. De invoering van verplichte onafhankelijke bemonstering van dikke fractie van gescheiden mest in oktober 2017 is ook een belangrijke bijdrage aan de vermindering van het probleem. 
Beperking grondruilconstructies kan ook bijdragen aan verminderen fraude Ingewikkelde constructies van grondruil zouden beperkt kunnen worden doordat de partijen alleen maar kunnen kiezen uit een aantal voorbeeldcontracten en dat bij grondruil maximaal maar twee partijen betrokken mogen worden: degene die de grond in gebruik neemt en de eigenaar/huurder van de grond. Wettelijk zou dus niet toegestaan moeten worden dat iemand die grond via grondruil heeft verkregen grond kan doorruilen met iemand anders.

Reflectie

Dit is een mogelijke oplossing maar de indruk bestaat dat deze vorm van fraude relatief beperkt is.

Loskoppelen transport van de intermediair

Door het loskoppelen van het transport van de mest van de mesthandelaar kan mogelijk de afzetprijs van mest worden verlaagd.

Reflectie

In de praktijk is transport in veel gevallen al losgekoppeld van de intermediair. Er zijn intermediairs die alleen maar bemiddelen in mestafzet en een transporteur inschakelen voor het echte transport. Voor export zijn dat in toenemende mate transporteurs uit oost Europa. Zonder intermediair zal de afnemer een transporteur inhuren. In het geval van een vrije markt kan bij schaarste aan transportcapaciteit de transporteur zijn prijs omhoog gooien. Omdat dit lucratief is, zal de transportcapaciteit snel worden uitgebreid waardoor de prijs weer zakt richting de kostprijs. De verwachting is daarom dat loskoppelen van het transport geen invloed heeft op de prijs.

Veiling waarop mest wordt aangeboden en afgenomen Door het gebruik van een veiling waarop de mest wordt aangeboden en afgenomen kan mogelijk de mestafzetprijs dalen.

Reflectie

In het geval van een overschot aan mest, tendeert de afzetprijs in de richting van het duurste alternatief voor de afzet van mest. Afnemers zullen de mest accepteren tegen een prijs die net iets lager ligt dan die van andere afnemers. Daarbij is de bovengrens van de afzetprijs gelijk aan die van het duurste alternatief.

De prijs die de veehouder moet betalen voor de afzet van mest, zal door de afzet van mest via een veiling niet wezenlijk anders worden. Op de veiling kan de rol van de intermediairs worden verschoven naar die van de afnemers. Het is echter de vraag of afnemers zelf op de veiling gaan bieden en vervolgens een transporteur regelen of dat ze ook dan de voorkeur geven aan een intermediair die dit werk van hun overneemt. De bestaande internetveilingen voor mest nemen geen grote vlucht omdat een groot deel van de mestafzet op basis van vertrouwen gaat met een vaste intermediair. Vertrouwen in een vaste intermediair is belangrijk omdat deze ook kan helpen in noodsituaties en je als afnemer weet wat je krijgt.

\subsection{Synthese}

Het verlagen van de mestafzetprijs door middel van verhoogde verplichte mestverwerking De belangrijkste prikkel tot fraude zijn de hoge mestafzetprijzen waardoor fraude lucratief is. Om de prikkel tot fraude weg te nemen, zou fraude niet langer lucratief moeten zijn. De enige manier om dit te realiseren is door zorg te dragen voor lage mestafzetprijzen. Hiervoor is het noodzakelijk dat de vraag toeneemt of dat het aanbod afneemt. Dit kan door:

- het in voldoende mate vergroten van de verplichte mestverwerkingspercentages waardoor de vraag vanuit de mestverwerking toeneemt. Hierbij kan de controle van de meststromen zich beperken tot die van en naar de mestverwerkingsinstallaties.

- het beperken van het aanbod door een reductie van het aantal dieren. Voor de veehouderij is het bedrijfseconomisch aantrekkelijker om mest te verwerken dan minder dieren te houden. 
Ten aanzien van de bemonstering van dikke fractie en de export:

- De recent ingevoerde onafhankelijke bemonstering van dikke fractie is een sterke verbetering.

- Voor export is het noodzakelijk om ook hier net als bij afzet van mest in de Nederlandse landbouw tegengestelde belangen te creëren. Hiervoor is afstemming met het buitenland noodzakelijk. Dit zou mogelijk in Europees verband in het kader van gezamenlijk mestbeleid kunnen worden opgepakt.

Overige mogelijke oplossingen die een bijdrage kunnen leveren zijn:

- Het controlesysteem van het fysieke transport verbeteren met foto's van de vracht.

- Wetgeving aanpassen zodat controleurs op basis van ongeloofwaardige gehaltes in de mest kunnen handhaven.

- De controle specifiek richten op van omvangrijke fraude verdachte actoren. Hiervoor zijn extra tools nodig om de bewijslast rond te kunnen krijgen.

- Beperking van ingewikkelde grondruilconstructies. 


\section{$6 \quad$ Conclusies}

Het is niet aannemelijk dat het handelen van mesthandelaren/-transporteurs/distributeurs een prijsopdrijvend effect heeft op de mestafzet.

Door de onderlinge concurrentie tussen de mesthandelaren kunnen de handelaren niet snel meer dan de kostprijs doorberekenen aan de klanten. Wel kan fraude het bonafide handelaren moeilijk maken om te concurreren, omdat fraude het makkelijker maakt om onder de kostprijs mest af te voeren.

De organisatie van de mestmarkt remt of versterkt de prikkel tot fraude op de volgende wijze:

- Bij afzet van bedrijfsvreemde mest in de Nederlandse landbouw wordt fraude geremd doordat er tegenstelde belangen zijn. De ontvangende partij wordt economisch benadeeld als er op papier meer mineralen worden geleverd dan in de praktijk; of andersom, als hij een overschot aan mineralen in de mest ontvangt en daardoor in de problemen komt.

- Bij export ontbreekt het tegengestelde belang waardoor dit de prikkel tot fraude juist versterkt.

- De niet transparante meststromen in de mesthandel waarbij mest opnieuw wordt gemengd en gelabeld maakt controle van de meststromen erg complex en versterkt de kans op fraude.

- In 2015 was er een gebrek aan mestafzetmogelijkheden doordat er onvoldoende hygiënisatie en/of andere mestverwerkingscapaciteit beschikbaar was waardoor onvoldoende mest kon worden geëxporteerd. Dit werkte fraude in de hand. De vraag is of dit een probleem is van de mesthandel maar ze werden wel geconfronteerd met een onmogelijke situatie.

Andere factoren die de prikkel tot fraude versterken zijn:

- De geringe pakkans.

- De toegenomen scheiding van mest waarbij de bemonstering van de dikke fractie erg fraudegevoelig is. Dit probleem is aangepakt met de in 2017 ingevoerde onafhankelijke bemonstering van dikke fractie.

Los van de genoemde elementen die de prikkel tot fraude versterken, is de hoge afzetprijs van mest de drijvende kracht achter de fraude die maakt dat fraude lucratief is. Op het moment dat fraude niet langer lucratief is, vervalt de reden om te frauderen.

Handelingsperspectieven voor de overheid om fraude(prikkels) als gevolg van de organisatie van de mesthandel af te remmen zijn met name:

- Het verlagen van de mestprijzen door het creëren van krapte op de mestmarkt. Dit kan bijvoorbeeld door:

- een grotere mestverwerking te realiseren dan het nationaal mestoverschot waardoor er krapte op de binnenlandse markt ontstaat en alleen de stroom naar de mestverwerkingsinstallatie hoeft te worden gecontroleerd. De extra mestverwerking zorgt ook voor een versnelling van de transitie naar een perspectiefvolle verwaarding van mest waardoor ook bij mestverwerking de prikkel tot fraude uiteindelijk kan wegvallen.

- een reductie van het aantal dieren waardoor het aanbod van mest op de mestmarkt kleiner wordt. Voor de veehouderij is het bedrijfseconomisch aantrekkelijker om mest te verwerken dan minder dieren te houden.

- Afstemming met de landen waarnaar mest wordt geëxporteerd gericht op het creëren van tegengesteld belang bij de export van mest.

- Meer gerichte controles op basis van afwijkende data/registraties. bijvoorbeeld: onwaarschijnlijke gehaltes in de mest; en ongeloofwaardige meststromen doordat ze bijvoorbeeld groter zijn dan de hygiënisatie- of de vervoerscapaciteit waar ze naar toe gaan of vandaan komen.

- Het aanpassen van de wet zodat de controlerende instanties de bevoegdheid hebben om bedrijven op basis van monsters met onrealistische mineralengehalten aan te pakken en voor het opbouwen van bewijslast. 


\section{Literatuur en websites}

Broens, D.F., H.H. Luesink en M. van Galen (2012) Biobased Park Cuijk; innovatieve contracten in de mestmarkt. Den Haag, LEI, Vertrouwelijk rapport.

Born, G.J. van den, H.H. Luesink, H. Verkerk, H.J. Mulder, J.N. Bosma, M.J.C. de Bode en O. Oenema (2009) Protocol voor monitoring landelijke mestmarkt onder een stelsel van gebruiksnormen, versie 2009. Wageningen, WOT Natuur en Milieu, Wageningen UR, WOT-werkdocument 166.

Buisonje, F. (2017) Fosfaatgehalten in de dikke fracties van gescheiden mest. Lelystad, Wageningen Livestock Research, Persoonlijke mededeling

CDM (2009)

Hoeksma, P., P.J.L. Derikx, N.W.M. Ogink en G.W.M. Willems (1996) Toetsing van prototype monstername-apparatuur voor drijfmest in transportwagens, Imag-dlo nota P 96-52.

Horne, P.C.M. van en H.H. Luesink (2009) Market for dry poultry manure, 2008-2-19, Den Haag, LEl, Interne notitie.

Koeijer, T. de, H. Luesink en G. Kruseman (2013) Effect van verplichte mestverwerking op de afzetprijs van mest: Empirisch-theoretische relatie tussen vraag en aanbod van varkensmest, in: Schroder, J.J . ; Baltussen, W.H.M. ; Koeijer, T.J. de; Leenstra, F.R. ; Velthof, G.L. ; Verdoes, N. ; Willems, J. ; Grinsven, H. van (2013) Ex ante evaluatie mestbeleid 2013: gevolgen van de invoering van verplichte mestverwerking en het afschaffen van productierechten in de veehouderij Den Haag: Planbureau voor de Leefomgeving (PBL), (PBL-publicatie 1176) - 43 p.

Koeijer, T.J. de, Buurma, J.S., Luesink, H.H., Ruijs, M.N.A. (2015) Beleid waterkwaliteit: kosten voor de landbouw: een quick scan: Een quick scan, LEI Wageningen UR, (Nota / LEI Wageningen UR LEI 2015-147) - 17 p.

Koeijer, T. de en H. Luesink (2016) Onafhankelijke bemonstering van vaste mest, globale indicatie van de kosten en administratieve lasten. Wageningen, LEI Wageningen UR, LEI rapport 2016-050

Koeijer, T.J. de, H.H. Luesink en P.W. Blokland (2017) MAMBO-modelbeschrijving en uitgangspunten in het kader van de Evaluatie van de Meststoffenwet 2016, Wageningen Economic Research, (Factsheet / Wageningen Economic Research 2017-044)

Luesink, H.H., P.W. Blokland en J.N. Bosma (2011) Monitoring mestmarkt 2010, Achtergronddocumentatie, LEI Wageningen UR, Den Haag, LEI-rapport 2011-048.

Monitoring Mestmarkt, www. monitoringmestmarkt.nl

Velthof, G.L., T. Koeijer, J.J. Schröder, M. Timmerman, A. Hooijboer, J. Rozemeijer, C. van Bruggen en P. Groenendijk (2017) Effecten van het mestbeleid op landbouw en milieu : Beantwoording van de ex-postvragen in het kader van de evaluatie van de meststoffenwet, Wageningen: Wageningen Environmental Research, (Wageningen Environmental Research rapport 2782) - 139 


\section{Bijlage 1 Effect van verplichte mestverwerking op de afzetprijs van mest}

\section{Empirisch-theoretische relatie tussen vraag en aanbod van varkensmest}

Tanja de Koeijer, Harry Luesink en Gideon Kruseman

30 september 2013

Inzicht in de relatie tussen vraag, aanbod en afzetprijzen is nodig om de effecten van een verplichte mestverwerking op de kosten van de afzet van mest voor producenten in de dierlijke productiesector te kunnen bepalen. Alhoewel de wetten van vraag en aanbod ook op de mestmarkt gelden, is de prijs van mest negatief sinds de invoering van mestregelgeving medio jaren tachtig. Dit betekent dat wanneer in het navolgende gesproken wordt over een 'stijgende prijs' dit vanuit het perspectief van de mestproducent een 'minder negatieve prijs' betekent en vanuit het perspectief van de afnemer een 'lagere vergoeding' bij de afname van mest. Feitelijk betekent een negatieve prijs voor mest dat mest gezien kan worden als een afvalproduct. Daarbij geeft een negatieve prijs voor mest aan dat er niet zozeer vraag naar mest is maar vraag naar afzetruimte voor mest. De mestproducent betaald voor afzetruimte van mest.

In deze notitie behandelen we echter vraag en aanbod van mest en niet van afzetruimte om zo het effect in beeld te kunnen brengen van verplichte mestverwerking op de mestafzetprijs.

Ook voor ondernemers die willen investeren in mestverwerking is inzicht in de te verwachten prijsontwikkeling cruciaal. Welke prijs mogen zij verwachten voor het te verwerken product en wat gebeurt er als meer mestverwerkingsinstallaties worden gebouwd? Ervaringen uit het verleden hebben geleerd dat enerzijds het opstarten van grootschalige mestverwerking een groot effect heeft op de prijs van mest. Door de extra vraag naar mest voor de mestverwerkingsinstallatie steeg de aanbodprijs van mest (werd minder negatief) waardoor de mestverwerkingsinstallaties minder geld ontvingen voor acceptatie van mest en niet langer rendabel waren (De Hoop et al., 2011). Anderzijds door het uitblijven van voldoende vraag naar mest, neemt de aanbodprijs steeds verder af (wordt meer negatief) waardoor ondernemers in de dierlijke productiesector met hoge afzetprijzen kampen waardoor een rendabele bedrijfsvoering in gevaar komt.

Hierna wordt uiteengezet hoe vraag, aanbod en prijzen van mest samenhangen aan de hand van een case voor de afzet en het aanbod van varkensmest in 2011. De relaties zijn geschat op basis van historische data met betrekking tot vraag, aanbod en prijzen van varkensmest. Vervolgens zal aan de hand van een fictief voorbeeld voor de realisatie van extra mestverwerkingscapaciteit worden aangegeven wat dit betekent voor de aanbodprijs van varkensmest. Op basis daarvan wordt bediscussieerd wat dit betekent voor de ondernemer in de mestverwerking en voor de ondernemers in de dierlijke productiesector.

\section{Relatie aanbod, vraag en aanbodprijs van mest.}

\section{De vraag}

In een situatie met een ruim aanbod (overschot) van dierlijke mest wordt de vraag naar mest bepaald door de prijs waarvoor de mest wordt aangeboden. De samenhang tussen aanbod en prijs is geanalyseerd aan de hand van empirische data van mest over de periode 1980-2011 aangevuld met theoretische inzichten. Aan de hand van een uitgewerkt voorbeeld voor de situatie van vrijwillige mestverwerking van varkensmest in het zuiden van het land is hierna de relatie tussen vraag, aanbod en prijs uitgewerkt. 
De vraag naar varkensmest kan worden onderverdeeld in verschillende deelmarkten. In figuur B1.1 geeft de gekleurde lijn de relatie tussen vraag en aanbodprijs weer. Hoe hoger de prijs hoe lager de vraag. Bij een positieve prijs bedraagt de vraag naar mest circa $18 \mathrm{mln}$. fosfaat. Daarvan bedraagt de vraag naar mest van de mestproducerende bedrijven zelf 6 miljoen $\mathrm{kg}$ fosfaat. Deze bovengrens is gebaseerd op een grove schatting van de prijs van concurrerende producten zoals kunstmest en op basis van expert judgement. Bij deze hoge prijs wordt de mest alleen aangewend voor eigen gebruik (blauwe lijn). Indien de prijs daalt van 3 naar circa - 12 euro per ton kan er tot circa $35 \mathrm{mln}$. $\mathrm{kg}$ fosfaat worden afgezet in de Nederlandse akkerbouw (rode lijn). Bij een nog lagere (meer negatieve) prijs stijgt de vraag tot circa $47 \mathrm{mln}$. $\mathrm{kg}$ fosfaat doordat er ook vraag naar gehygiëniseerde mest vanuit de exportgebieden (groene lijn) ontstaat. Bij een nog lagere afzetprijs onder de 25 euro per ton ontstaat er vraag vanuit verder weggelegen exportgebieden. Voor deze prijs kan de mest worden verwerkt en naar verder weggelegen exportmarkten worden getransporteerd.

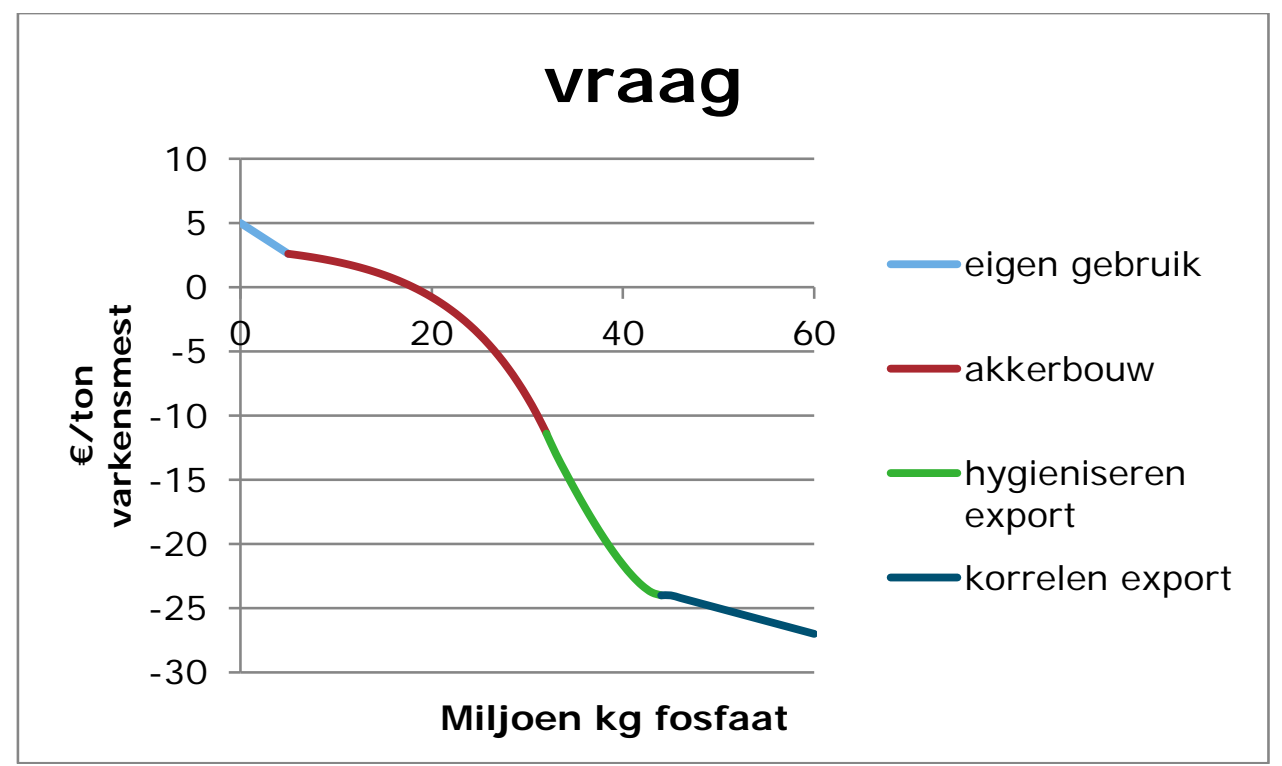

Figuur B1.1 Relatie vraag (onderverdeeld in deelmarkten) en aanbodprijs voor varkensmest in het zuidelijk zandgebied voor 2011

Bron: Monitoring mestmarkt 2011 en Wageningen Economic Research.

De curve in figuur B1.1 is opgebouwd uit de cumulatieve vraagcurves van de deelmarkten bij verschillende prijsniveaus. De vraag naar mest in de deelmarkten is verschillend. De vraag naar mest voor eigen gebruik heeft een sterk inelastisch gedeelte dat ingegeven wordt door de beperking door de wettelijke normen voor het gebruik van mest en mineralen (figuur B1.2). 


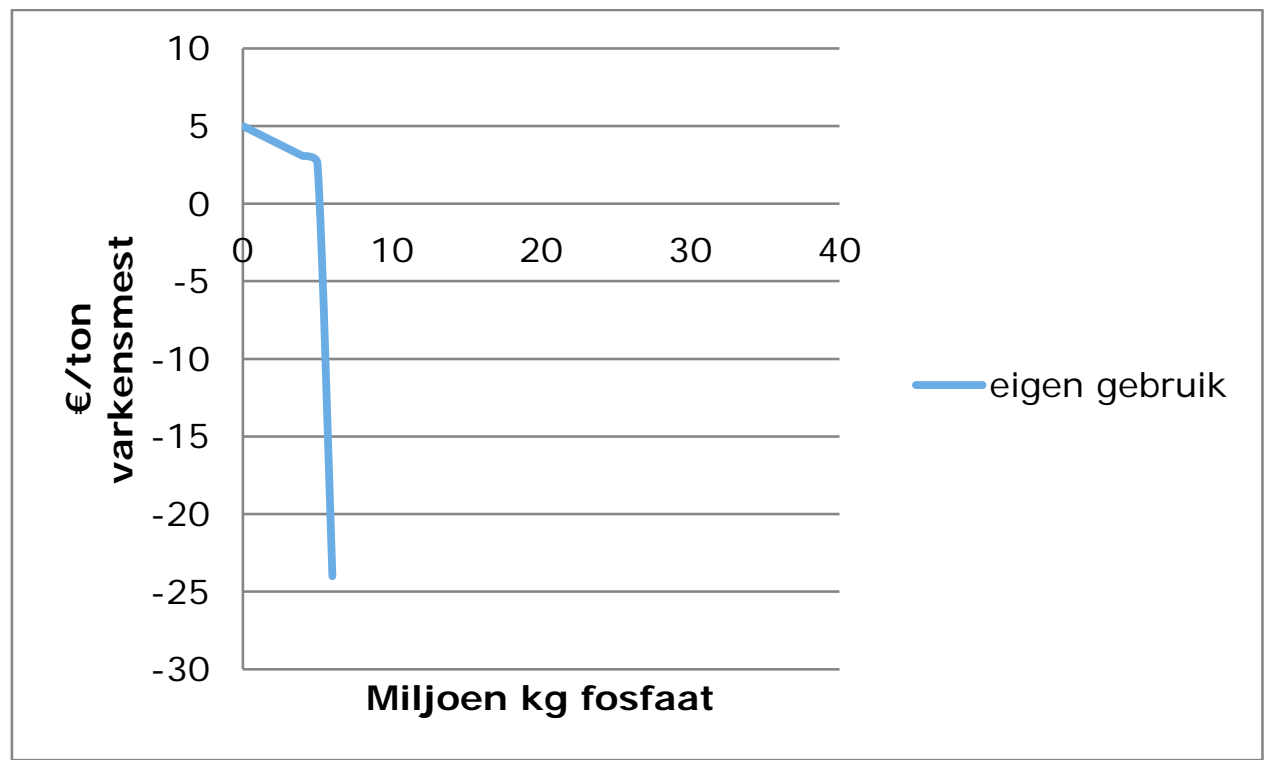

Figuur B1.2 Relatie vraag voor eigen gebruik en aanbodprijs voor varkensmest in het zuidelijk zandgebied voor 2011

Bron: Wageningen Economic Research.

De vraag naar bedrijfsvreemde mest door de Nederlandse landbouw, met name akkerbouw en tuinbouw wordt bepaald door de mestnormen en de mestprijs. Dit resulteert in een vraagcurve zoals aangegeven in figuur B1.3.

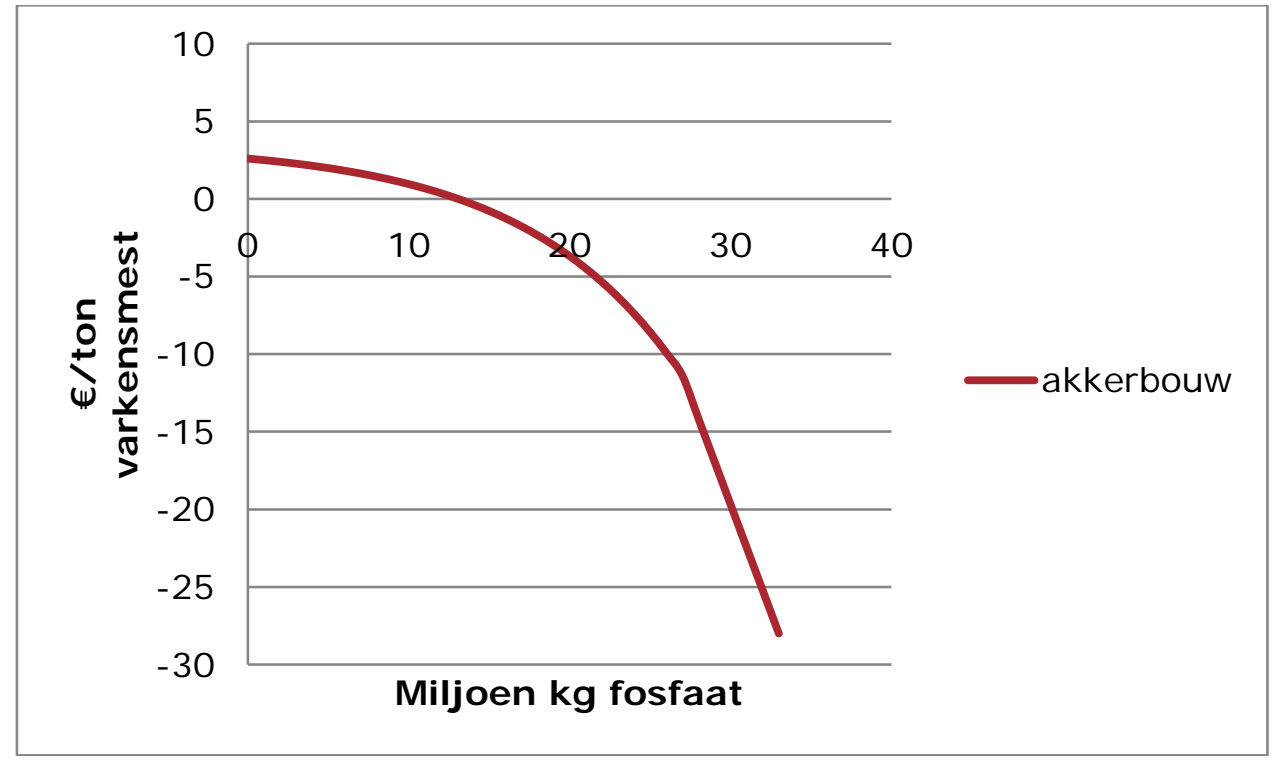

Figuur B1.3 Relatie vraag vanuit de Nederlandse landbouw naar bedrijfsvreemde mest (vooral akkerbouw) en aanbodprijs voor varkensmest in het zuidelijk zandgebied voor 2011 Bron: Monitoring mestmarkt 2011 en Wageningen Economic Research

De vraag naar bedrijfsvreemde mest is minder inelastisch dan de vraag naar eigen mest doordat de vraag meer afhankelijk is van de mestprijzen. De vraag naar mest voor export begint pas bij sterk negatieve mestprijzen. Bij hogere (minder negatieve) mestprijzen is het economisch niet interessant om mest te exporteren en het daarvoor zo nodig ook te verwerken.

\section{Het aanbod}

Het aanbod van mest is nauwelijks afhankelijk van de prijs van mest. Dit komt doordat mest een bijproduct is van de productie van vlees, melk en eieren. De totale verhouding van kosten en 
opbrengsten bepaalt of de veestapel en daarmee de mestproductie wordt aangepast. Bij relatief grote prijsveranderingen kan het effect op de kosten voor de afzet van mest zodanig zijn dat de veestapel daadwerkelijk wordt aangepast. De mestproductie en daarmee het aanbod reageert dus zwak op een verandering in de prijs van mest. In economische termen betekent dit dat het aanbod van mest inelastisch is. Dat wil zeggen dat bij een kleine variatie in het aanbod de prijs sterk varieert. In figuur B1.4 is dit geillustreerd. De grijze lijn geeft de relatie tussen het aanbod van varkensmest en de afzetprijs van mest weer. De curve vertoont een steil verloop waardoor bij een kleine verandering in het aanbod de prijs sterk varieert.

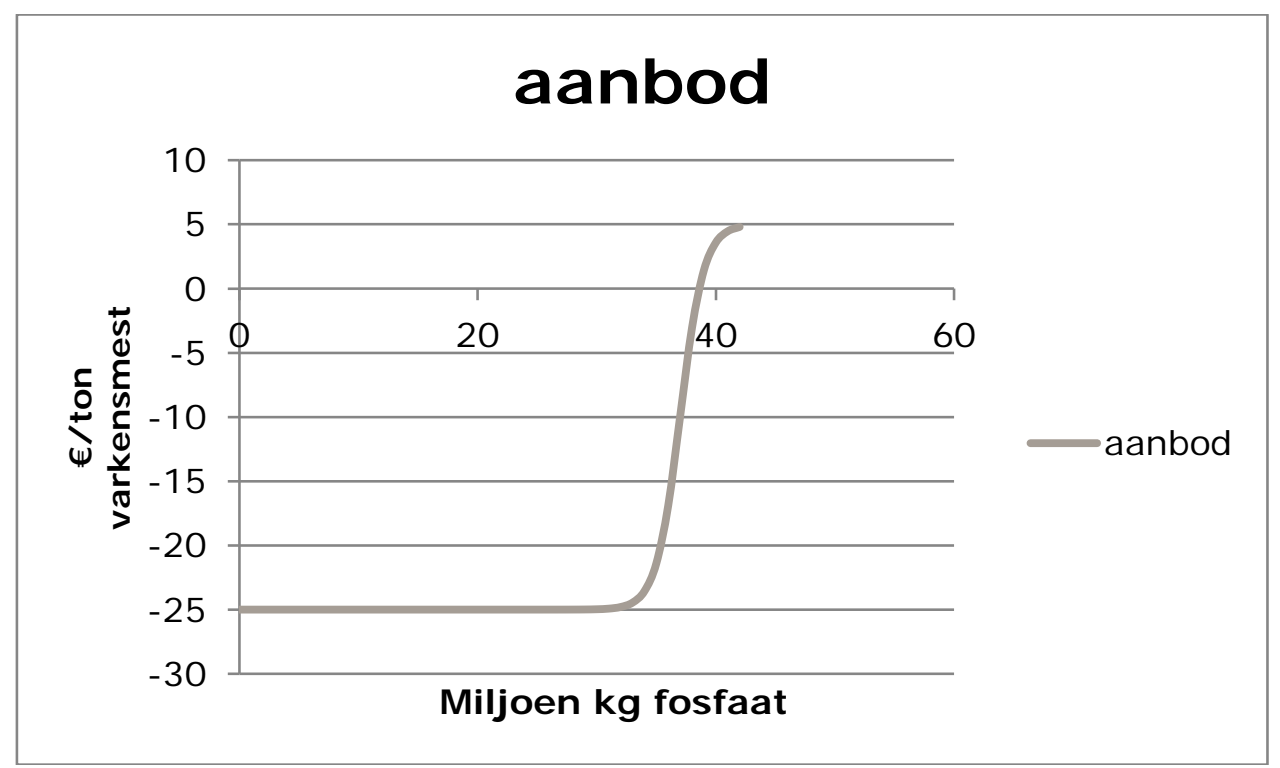

Figuur B1.4 Relatie aanbod en prijs van varkensmest voor 2011 in het zuidelijk zandgebied Bron: Wageningen Economic Research.

De markt streeft naar evenwicht waarbij vraag en aanbod aan elkaar gelijk zijn. In 2011 is voor het zuidelijk zandgebied van varkensdrijfmest de evenwichtsprijs circa 17 euro/ton (figuur B1.5).

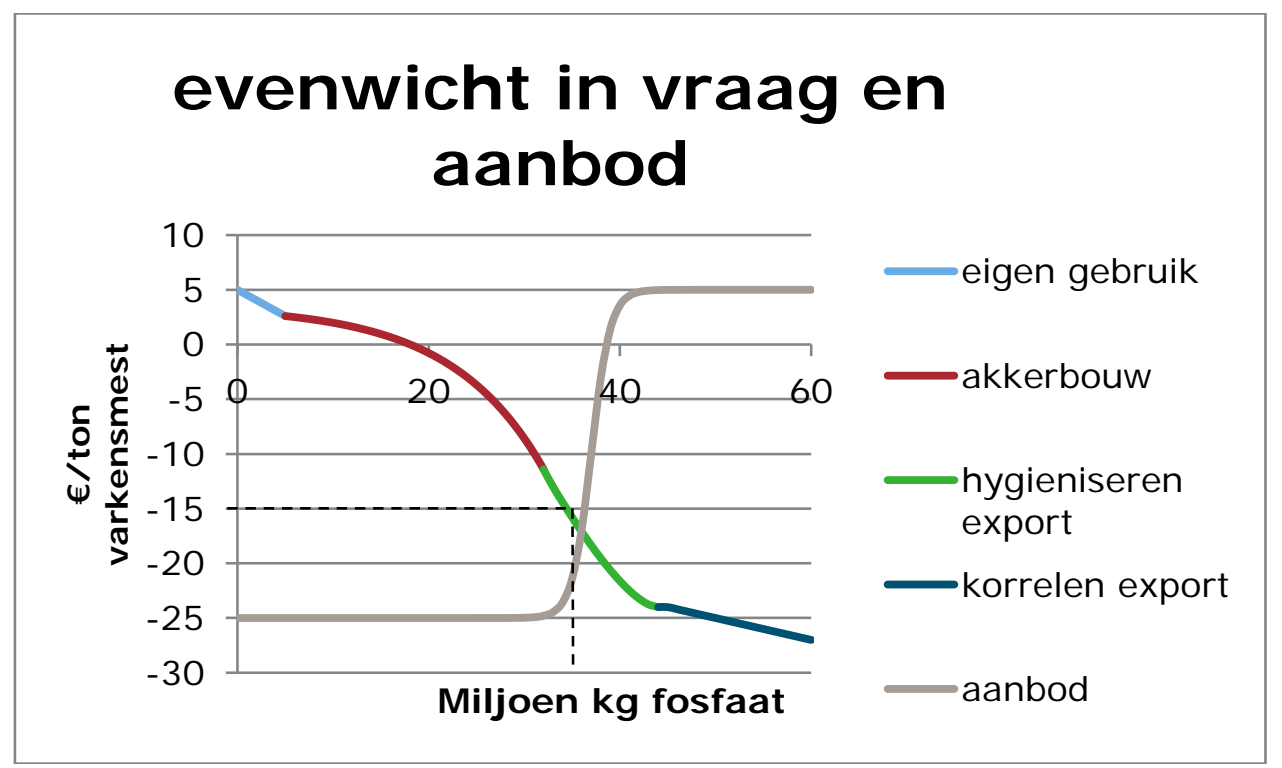

Figuur B1.5 De evenwichtsprijs voor de vraag en het aanbod van varkensmest in 2011 in het zuidelijk zandgebied Bron: Monitoring mestmarkt 2011 en Wageningen Economic Research. 


\section{Het effect van extra mestverwerking op de prijs van mest}

Bij de realisatie van extra mestverwerkingscapaciteit vindt in feite een vergroting van de vraag naar mest plaats. De mestverwerkingsinstallatie vraagt mest om te kunnen verwerken. Door deze extra vraag verschuift de vraagcurve in figuur B1.5 met de omvang van de extra vraag naar rechts. Er ontstaat door deze extra vraag een nieuwe evenwichtsprijs (figuur B1.6). Zoals de figuur laat zien heeft de relatief kleine toename van de vraag met 6\% (van circa 37 naar $39 \mathrm{mln}$. $\mathrm{kg}$ fosfaat) met als gevolg een verschuiving in de het relatieve aandeel van verschillende vraagcomponenten, een relatief groot effect op de afzetprijs van 35\% (van - 17 naar - 11 euro/ton mest).

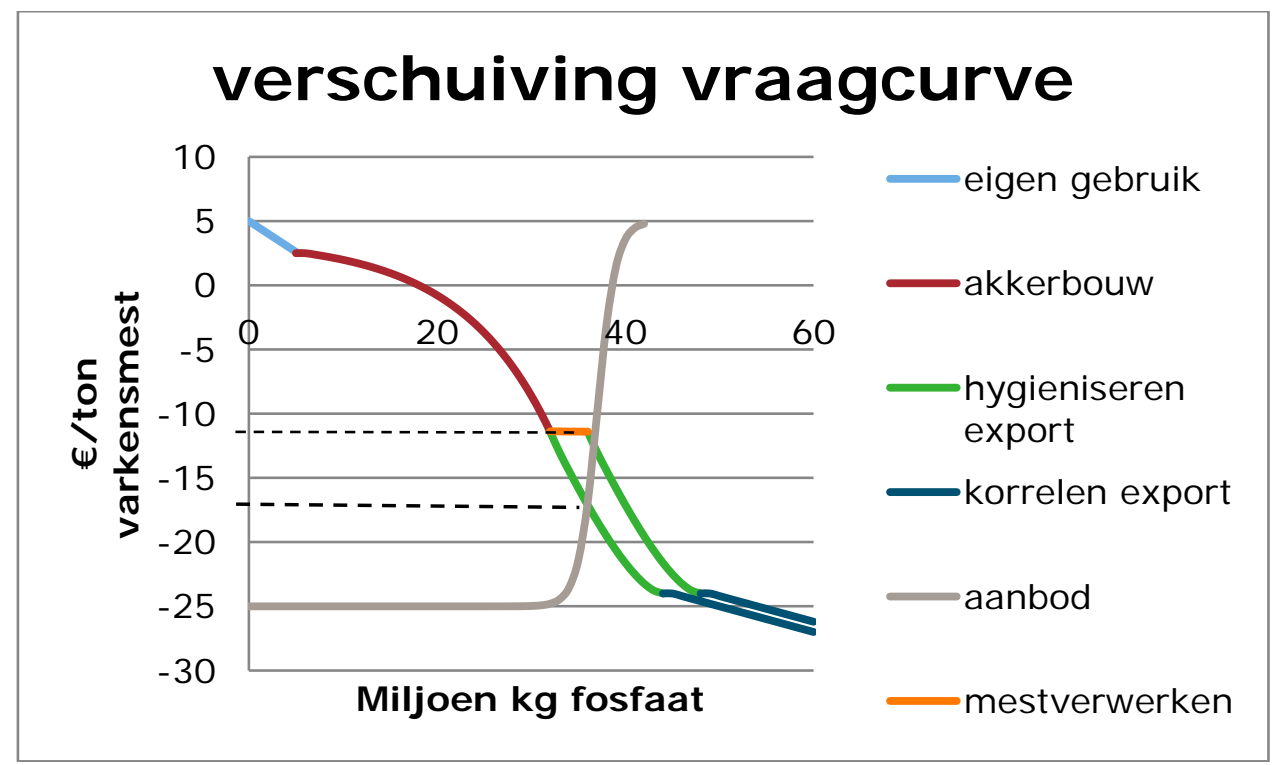

Figuur B1.6 Effect verschuiving van vraag naar varkensmest in het zuidelijk zandgebied door extra mestverwerkingscapaciteit

Bron: Monitoring mestmarkt 2011 en Wageningen Economic Research.

Als mestverwerking niet verplicht wordt zal zo'n situatie niet gauw ontstaan. Er zal dan alleen maar mestverwerking ontstaan wanneer de prijs op het niveau van komt waarbij er vraag vanuit de verder weg gelegen exportgebieden komt en de mest dus moet worden verwerkt. Anders is het risico voor de mestverwerkers veel te groot. De situatie in figuur B1.6 kan ontstaan wanneer er mestverwerkingscapaciteit gecreëerd wordt waarbij de operationele kosten gedekt worden bij een mestprijs van - 11 euro/ton. ${ }^{13}$ Een dergelijke situatie kan slechts gedurende een korte termijn bestaan omdat de mestverwerker anders failliet zal gaan doordat de vaste kosten niet worden goedgemaakt. Mestverwerking zonder mestverwerkingsverplichting kan wel ontstaan als de vraagcurve naar links verschuift bijvoorbeeld door aanscherping van de mest normen zie figuur B1.7.

\footnotetext{
13 In het voorbeeld is uitgegaan van mestverwerking in de vorm van het korrelen van mest voor de export van mest over afstanden groter dan $200 \mathrm{~km}$ gebaseerd op de aanname dat de afzetmogelijkheden voor gehygiëniseerde mest in dichterbij gelegen buitenlandse gebieden nagenoeg verzadigd is (De Koeijer et al., 2012)
} 


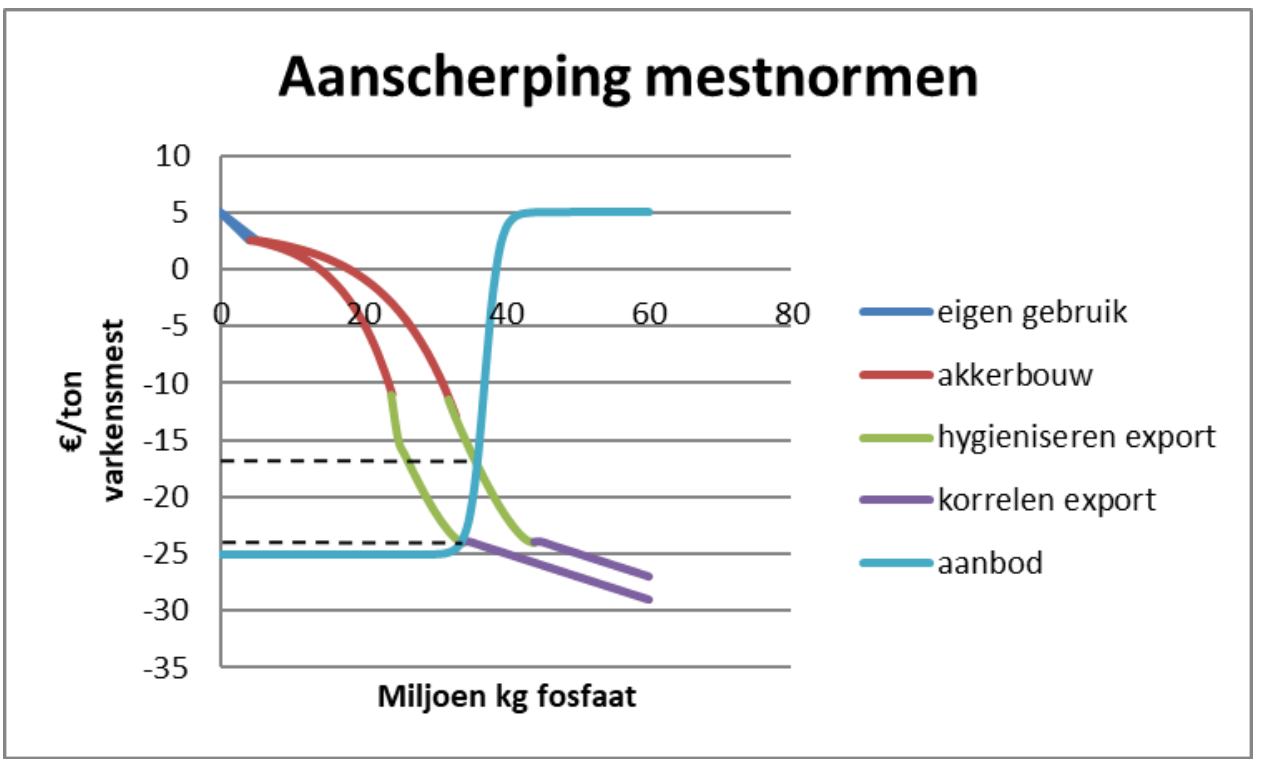

Figuur B1.7 Effect verschuiving van vraag door aanscherping mestnormen Bron: Monitoring mestmarkt 2011 en Wageningen Economic Research.

\section{Betekenis voor wetsvoorstel verplichte mestverwerking}

Figuur B1.6 illustreert het belang van verplichte mestverwerking. Bij een toename van de mestverwerkingscapaciteit neemt de prijs van de aangeboden mest zodanig toe (de poortprijs die verwerkers ontvangen neemt af) dat de rendabiliteit van de mestverwerkingsinstallatie in gevaar kan komen zoals we in het verleden hebben gezien. Door ondernemers te verplichten een deel van hun mest aan de mestverwerking aan te bieden wordt dit risico voor mestverwerkers kleiner waardoor het voor hen eerder aantrekkelijk zal zijn om een mestverwerkingsinstallatie te bouwen.

Tegelijkertijd is verplichte mestverwerking ook voor de dierlijke productiesector aantrekkelijk. Door de huidige situatie op de mestmarkt met een relatief groot aanbod en een achterblijvende vraag zijn de prijzen voor mest erg laag (sterk negatief) en kampen de veehouders dus met hoge mestafzetkosten. Door de verplichte mestverwerking daalt de prijs van de niet-verwerkte mest relatief sterk. Afhankelijk van de verhouding verplichte mestverwerking en niet verwerkte mest en de respons van de akkerbouwers zouden de afzetkosten voor veehouders op termijn zelfs kunnen dalen zoals ook is berekend in De Koeijer et al. (2012).

Door verplichte mestverwerking worden in feite twee verschillende markten voor de afzet van mest gecreëerd: 1) een markt voor verplichte mestverwerking met de daarbij behorende relatief hoge kosten voor de afzet van mest en 2 ) een markt voor de resterende mest met relatief veel hogere mestprijzen en dus lagere afzetkosten.

De optimale omvang van de mestverwerking luistert erg nauw. Bij een te grote omvang van de verplichte mestverwerking zal de afzet van de mest in de Nederlandse landbouw afnemen doordat 1) er onvoldoende mest beschikbaar is voor de Nederlandse markt en 2) de prijzen sterk stijgen waardoor kunstmest weer een groter deel van de bemesting kan gaan innemen. Bij een te kleine omvang blijft de druk op de mestmarkt als gevolg van het overschot hoog waardoor de prijzen voor de afzet van mest niet dalen. Gecombineerd met de hogere prijzen benodigd voor de verwerking van mest wordt dan de rendabiliteit van de veehouderij verder aangetast

\section{Referenties}

Hoop, J. de, F. Bunte, P.W. Blokland, H. van Kernebeek, H. Vrolijk, H. Luesink en T. de Koeijer (2011) Economische analyse van de mestmarkt; opties voor het stimuleren van innovaties. Den Haag LEIrapport 2011-043.

Koeijer, T.J. de, H.H. Luesink en A. van den Ham (2012) Ex-ante analyse wetsvoorstel stelsel van verantwoorde mestafzet sept 2012. Den Haag LEI-nota 12-085.

Monitoring mestmarkt (2011) www.monitoringmestmarkt.nl 


\section{Bijlage 2 Aanvoer en afvoer van mest van vervoerders (in $1.000 \mathrm{~kg}$ mest) in 2015 naar mestsoort}

\begin{tabular}{lrrr} 
& Afvoer & Aanvoer & Aanvoer/ afvoer \\
19 Rundvee-mest vleeskalveren, rosévlees & 18.104 & 51.146 & 2,8 \\
\hline 61 Geiten-vaste mest & 7.709 & 20.184 & 2,6 \\
\hline 40 Varkens-vaste mest & 5.205 & 13.185 & 2,5 \\
\hline 10 Rundvee-vaste mest & 24.651 & 35.620 & 1,4 \\
\hline 33 Kippen-mestband + nadroog & 13.037 & 4.608 & 0,4 \\
\hline 17 Rundvee-bewerkte vleeskalverdrijfmest & 28.942 & 43.213 & 1,5 \\
\hline 116 Overige mestsoorten & 74.075 & 38.710 & 0,5 \\
\hline 76 Nertsen-drijfmest & 31.860 & 75.944 & 2,4 \\
\hline 25 Paarden-vaste mest & 94.479 & 65.253 & 0,7 \\
\hline 110 Champost (afvoer van champignonkweker) & 102.887 & 33.176 & 0,3 \\
\hline 14 Rundvee-drijfmest behalve van vleeskalveren & 139.492 & 227.580 & 1,6 \\
\hline 41 Varkens-gier en filtraat na mestscheiding & 515.487 & 121.926 & 0,2 \\
\hline 75 Nertsen-vaste mest & 8.319 & 7.780 & 0,9 \\
\hline 46 Varkensdrijfmest (op)fokvarkens incl. biggen & 79.602 & 381.993 & 4,8 \\
\hline 13 Rundvee-koek na mestscheiding & 51.651 & 71.031 & 1,4 \\
\hline 32 Kippen-mestband & 55.716 & 23.418 & 0,4 \\
\hline 39 Vleeskuikens en parelhoenders, alle systemen & 46.775 & 58.876 & 1,3 \\
\hline 35 Kippen-strooisel (incl. volière/scharrel) & 49.484 & 33.313 & 0,7 \\
\hline 43 Varkens-koek na mestscheiding & 189.310 & 88.136 & 0,5 \\
\hline 50 Varkensdrijfmest vleesvarkens & 1.232 .777 & 1.389 .885 & 1,1 \\
\hline Overig & 80.391 & 53.004 & 0,7 \\
\hline Total & 2.849 .953 & 2.837 .981 & 1,0 \\
\hline
\end{tabular}




\section{Bijlage 3 Fosfaat- en stikstofgehalten in de aangevoerde en afgevoerde mest ( kg per $1.000 \mathrm{~kg}$ mest) bij vervoerders in 2015 naar mestsoort}

\begin{tabular}{lrrrr} 
& Afvoer & & \multicolumn{2}{c}{ Aanvoer } \\
& Fosfaat & Stikstof & Fosfaat & Stikstof \\
\cline { 2 - 4 } 19 Rundvee-mest vleeskalveren, rosévlees & 2,7 & 5.5 & 2,3 & 5,3 \\
\hline 61 Geiten-vaste mest & 5,0 & 7,8 & 7,3 & 11,8 \\
\hline 40 Varkens-vaste mest & 11,6 & 9,6 & 9,7 & 10,2 \\
\hline 10 Rundvee-vaste mest & 4,6 & 7,4 & 4,3 & 7,8 \\
\hline 33 Kippen-mestband + nadroog & 21,6 & 19,1 & 21,8 & 24,2 \\
\hline 17 Rundvee-bewerkte vleeskalverdrijfmest & 5,9 & 5,5 & 5,2 & 4,5 \\
\hline 116 Overige mestsoorten & 4,1 & 5,2 & 4,4 & 7,0 \\
\hline 76 Nertsen-drijfmest & 3,7 & 5,3 & 5,2 & 8,2 \\
\hline 25 Paarden-vaste mest & 3,4 & 6,0 & 2,9 & 5,4 \\
\hline 110 Champost (afvoer van champignonkweker) & 4,4 & 8,0 & 4,0 & 7,7 \\
\hline 14 Rundvee-drijfmest behalve van vleeskalveren & 1,9 & 4,3 & 1,7 & 4,3 \\
\hline 41 Varkens-gier en filtraat na mestscheiding & 1,0 & 4,1 & 1,3 & 5,4 \\
\hline 75 Nertsen-vaste mest & 40,4 & 18,5 & 49,6 & 23,1 \\
\hline 46 Varkensdrijfmest (op)fokvarkens inclusief biggen & 2,8 & 4,9 & 3,2 & 4,5 \\
\hline 13 Rundvee-koek na mestscheiding & 14,9 & 18,1 & 9,8 & 17,3 \\
\hline 32 Kippen-mestband & 18,7 & 19,0 & 19,0 & 22,6 \\
\hline 39 Vleeskuikens en parelhoenders, alle systemen & 17,8 & 24,0 & 14,4 & 28,1 \\
\hline 35 Kippen-strooisel (inclusief volière/scharrel) & 19,7 & 21,4 & 23,6 & 23,4 \\
\hline 43 Varkens-koek na mestscheiding & 22,6 & 14,6 & 22,4 & 15,5 \\
\hline 50 Varkensdrijfmest vleesvarkens & 3,5 & 5,7 & 4,2 & 6,6 \\
\hline Overig & 4,5 & 7,2 & 2,6 & 5,6 \\
\hline Total & 5,5 & 7,2 & 5,1 & 7,5 \\
\hline
\end{tabular}




\section{Bijlage 4 Resultaten interviews en workshop}

\section{Genoemde mogelijkheden om te frauderen}

- Zogenaamde export van mest die eigenlijk in Nederland wordt afgezet;

- Knoeien met gewicht via de weegbrug, bijvoorbeeld door maar een deel van de wagen op de weegbrug te zetten, of door voor en na het wegen wat meer of minder lucht in te laten bij het gebruik van automatische weeginstallaties op vrachtwagens die met luchtdruk werken;

- Contracteren of rouleren van grond; het gaat hier om 'lege' contracten, bijvoorbeeld met beheerders/ eigenaren van natuurgrond, dijken, hobbygrond of sportvelden;

- Mestopslag bij leegstaande bedrijven;

- Mestscheiding waarbij het gehalte dikke fractie wordt 'afgestemd' op de toegestane hoeveelheid en de dunne fractie illegaal wordt uitgereden;

- Kunstmest of spuiwater bijmengen waardoor gehaltes hoger of lager lijken;

- Monsters in de magnetron doen waardoor het water uit de mest verdampt en de gehalten aan droge stof en mineralen hoger worden;

- Knoeien met monsters waarbij afgesloten monsters worden geopend, vervolgens met het monster geknoeid wordt en het monster daarna weer afgesloten wordt;

- Intermediair vermeldt mondeling te lage gehaltes. Achteraf blijken dan de gehaltes die de intermediair heeft doorgegeven te laag te zijn geweest op basis van de laboratorium uitslagen;

- Verkeerde mestcode invullen of knoeien met mestbonnen.

\section{Genoemde prikkels die fraude in de hand kunnen werken}

De genoemde prikkels om te frauderen zijn onderverdeeld in economische, institutionele en technische prikkels. Daarnaast spelen ook morele belemmeringen en/of negatieve sociale druk een rol.

\section{Economische prikkels}

Economische prikkels die kunnen aanzetten tot mestfraude zijn (op basis van interviews en workshop):

- Te hoge mestafzetprijzen waardoor er veel kan worden verdiend bij fraude;

- Te krappe bemestingsnormen waardoor acceptatie van 'zwarte' mest zeer aantrekkelijk is;

- Lage inkomsten waardoor de hoge mestafzetkosten extra zwaar wegen.

Daarbij moet worden opgemerkt dat het probleem voor pluimveemest kleiner is dan voor andere mestsoorten. Deze mest is relatief droog en kan goed worden verwaard 1) door het te korrelen, 2) als champignonsubstraat en 3) door verbranding. De afzetkosten voor pluimveemest zijn dan ook laag en zouden momenteel (voorjaar 2017) zelfs 0 euro per ton bedragen voor pluimveemestsoorten met droge stof gehalten van $70 \%$ of hoger. Het verwerken van de mest tot droge korrels kost weliswaar geld maar het levert ook wat op.

Technische belemmeringen

Technische belemmeringen die kunnen leiden tot mestfraude zijn (op basis van interviews en workshop):

- Makkelijk om te frauderen met de gewichtmeting op de vrachtwagen bij het AGR/ GPS systeem dat automatisch laden en lossen registreert. De gewichtmeting wordt gedaan op basis van luchtdruk. Door lucht in en uit het systeem te laten kan de gewichtmeting worden beïnvloed;

- Nieuw alternatief systeem van AGR/GPS (e-CMR) maakt fraude weer gemakkelijker;

- Systeem van mestscheiding is geïntroduceerd toen het controlesysteem voor vaste mestsoorten nog niet waterdicht was. Verschillende lekken maakten het mogelijk om te frauderen;

- Metingen van monsters kunnen verschillend uitpakken in verschillende laboratoria doordat de bij de bemonstering afwijkingen van 15\% mogelijk zijn (Hoeksma, 199x....) hierdoor is het moeilijk om de mestboekhouding sluitend te krijgen. Dit geldt met name voor bedrijven met een relatief grote mestafvoer; 
- Akkerbouwers weten bij de afname van de mest niet hoeveel fosfaat er in de mest zit; De laboratoriumuitslagen komen pas nadat de mest is geleverd waardoor de akkerbouwer niet meer kan bijsturen als hij teveel heeft gekregen.

Institutionele belemmeringen

Tijdens de interviews en workshop kwamen de onderstaande prikkels voor fraude naar voren die worden veroorzaakt door institutionele belemmeringen:

- Gebruiksnormen zijn te laag waardoor het accepteren van 'zwarte' mest aantrekkelijk is;

- Forfaits van de dikke fractie zijn te hoog waardoor bij fraude eenvoudig gebruik gemaakt kan worden van deze forfaits in plaats van het werkelijke (lagere) gehalte;

- Pakkans bij fraude is te klein (0,1\% van de monsters wordt fysiek gecontroleerd (Velthof et al., 2017)), er wordt onvoldoende gehandhaafd en er is te weinig capaciteit bij NVWA;

- Mest met afwijkende gehaltes wordt te gemakkelijk geaccepteerd door RVO; ook als de cijfers duidelijk niet kloppen of niet kunnen kloppen. Juridisch gezien zijn afwijkende gehaltes niet strafbaar. Als er geen grenzen worden gesteld werkt dit echter fraude in de hand;

- Kleine fraudes worden aangepakt als de administratie niet klopt. De grote fraudeurs - bijvoorbeeld door mestscheiding - zorgen echter wel dat op papier alles klopt en worden niet of veel te weinig aangepakt. 'Als het op papier maar klopt' lijkt het adagium te zijn;

- Systeem voor onafhankelijke monstername is logistiek ingewikkeld omdat transporteur en controleur tegelijk op het laad- of het lospunt aanwezig moeten zijn;

- Onafhankelijke monstername is niet waterdicht. Monsternemers zijn (ook) beïnvloedbaar;

- Export moet 12 uur van tevoren aangemeld worden. Dit is lang niet altijd te realiseren, bijvoorbeeld bij extreme weersomstandigheden;

- Intermediairs hoeven de stikstof in de mestboekhouding niet te verantwoorden, hierdoor is fraude makkelijker doordat de administratie alleen voor fosfaat moet kloppen.

Negatieve sociale druk

Tijdens de interviews werd ook veel gezegd dat zou kunnen wijzen op negatieve sociale druk waardoor de drempel om fraude te plegen wordt verlaagd. Uitspraken die hierop duiden zijn:

- Door lage bemestingsnormen wordt het bijna moreel goed/aanvaardbaar gevonden om gewassen ondanks bureaucratische regels passend te bemesten; het is immers 'not done' om gewassen te weinig te voeden;

- Fraude werkt fraude in de hand. Ondernemers moeten afhaken of mee doen;

- Fraude in de keten wordt professioneel aangepakt. Het lijkt wel in de richting van georganiseerde misdaad te gaan; Fraudeurs deinzen nergens voor terug; ook niet voor intimidatie en bedreigingen. Daarom komen er weinig tips vanuit de sector door klokkenluiders dat er fraude wordt gepleegd. Mensen durven niet;

- Gemakkelijker om te frauderen dan de bedrijfsvoering aan te passen om op het scherpst van de snede te kunnen bemesten;

- Varkenshouders nemen bewust het risico om 'zwarte' mest af te voeren. Als ze controle krijgen, hebben ze hun verhaal klaar;

- Adviseurs nemen initiatief om met name die boeren die het financieel moeilijk hebben te adviseren mest tegen lagere kosten (middels fraude) af te voeren.

\section{Genoemde oplossingen}

\section{Economische oplossingen}

- Mestverwaarding is belangrijk, hierdoor zou de mestafzetprijs omlaag kunnen waardoor de prikkel tot fraude afneemt;

- Het vergroten van de mest export waardoor de kosten van de mestafzet omlaag gaan.

Vanuit de workshopdeelnemers werden hier nog de volgende financiële oplossingen aan toegevoegd:

- Het collectief heffen van mestafzetkosten en verhandelen van mest in een soort staatsbedrijf (zoals nu ook met vuilnis gebeurt). De heffingen zouden benut kunnen worden voor innovaties in mestverwerking of -verwaarding. Als een ondernemer dan mest naar een verwerker brengt, zou hij 
hier ook iets voor terug moeten krijgen. Op die manier wordt de prikkel om te frauderen weg genomen. De ondernemer krijgt immers geld terug voor verwerkte mest. Eerder is ook al eens nagedacht over dit idee. Het is er toen niet gekomen. In plaats daarvan kwam er de mestverwerkingsplicht;

- Krapte creëren op de mestmarkt door meer mest verplicht te verwerken dan nodig zou zijn voor de Nederlandse landbouw. In dat geval moeten veehouders meer betalen voor mestverwerking en export maar omdat dan een aanbod gecreëerd wordt op de binnenlandse markt die lager is dan de vraag zal de akkerbouwer weer gaan betalen voor het leveren van mest. Dit zou per saldo aantrekkelijk kunnen zijn voor de veehouders. Niet alle workshopdeelnemers geloven echter dat dit zou kunnen werken;

- Sturen in vraag en aanbod, bijvoorbeeld door de plaatsingsruimte te verhogen. Dit kan bijvoorbeeld door het areaal grasland te verhogen en door de gebruiksnormen te verhogen in lijn met de hogere opbrengsten;

- Ook de strikte scheiding tussen dierlijke mest en kunstmest zou kunnen worden aangepast zodat meer dierlijke stikstof kan worden afgezet.

\section{Technische oplossingen}

Tijdens de interviews kwamen de volgende technische oplossingen naar voren:

- AGR/ GPS systeem bij laden en lossen, gecombineerd met digitale foto van vracht mest bij laden en lossen;

- Goed functionerende mestverwerking en meer mestverwerkingscapaciteit, evenredig verspreid over het land waardoor de mestmarkt meer in evenwicht is en de mestafzetprijzen mogelijk iets kunnen dalen;

- meer mestopslagcapaciteit, met name in Noord Nederland waardoor piekbelastingen op de mestmarkt en bijbehorende pieken in de afzetprijs kunnen verminderen.

Vanuit de workshop werd hier het volgende over gezegd:

- Wie gaat de digitale foto bekijken?

- De tijd tussen monstername en bemesten is nu drie dagen of langer. De mest ligt dus al op het land voordat de akkerbouwer weet hoe de samenstelling van de mest eruit ziet. Eigenlijk is er dus een techniek nodig die de gehaltes in de mest 'on the spot' kan meten. Dit zal niet gemakkelijk zijn. De techniek moet minstens zo nauwkeurig zijn als de huidige meetapparatuur.

\section{Institutionele oplossingen}

Verreweg de meeste oplossingen die tijdens de workshop en de interviews naar voren kwamen, waren institutioneel van aard. Er wordt een onderscheid gemaakt naar institutionele oplossingen met betrekking tot de teelt, institutionele oplossingen met betrekking tot certificering en vaste afzet, institutionele oplossingen om strenger en gerichter te kunnen handhaven en institutionele oplossingen over de wijze van bemonsteren.

Institutionele oplossingen met betrekking tot de teelt

De volgende institutionele oplossingen die betrekking hebben op de teelt kwamen tijdens de interviews naar voren:

- Mestfraude aanpakken door ook naar stikstof te kijken. Hierdoor ontstaat een completer beeld en kunnen er minder gemakkelijk zaken verbloemd worden;

- Aanpassen gebruiksnormen aan de onttrekking met het gewas;

- Volumebeperking/ha voor dunne fractie;

- MINAS weer invoeren;

- Strikte scheiding kunstmest - dierlijke mest heroverwegen. Juist dierlijke mest verbetert bodemstructuur en bodemleven;

- Zolang borging in mestketen niet voldoende op peil is, uitgaan van forfaitaire gehaltes i.p.v. gemakkelijk te beïnvloeden metingen; 
- Kleiner of geen overschot afdwingen via minder dieren waardoor het aanbod van mest afneemt en dus de mestafzetprijs zal dalen;

- mestnormen naar landbouwkundige waarden/ verhogen gebruiksnormen waardoor de vraag kan toenemen en dus de afzetprijs kan dalen;

- Mineralenconcentraten als kunstmest aanmerken waardoor de vraag kan toenemen en dus de afzetprijs kan dalen.

Tijdens de workshop wordt hierover het volgende gezegd:

- In plaats van het realiseren van een kleiner overschot of minder dieren kan er ook minder natuur gemaakt worden zodat meer landbouwgrond beschikbaar komt;

- De plaatsingsruimte voor mest moet vergroot worden, niet alleen via het verruimen van de gebruiksnormen maar ook door meer grasland te creëren, bijvoorbeeld in de Markerwaard;

- De gebruiksnormen zouden opnieuw bekeken moeten worden omdat de gewasopbrengsten in de loop der jaren hoger zijn geworden. De gebruiksnormen zouden daarop aangepast moeten worden.

Institutionele oplossingen met betrekking tot certificering en vaste afzet Hierover werd tijdens de interviews het volgende gezegd:

- Mestcertificatie en vaste mestafzet relaties; mestintermediairs meenemen in goede mestketen. Op die manier kan tegengewicht ontstaan tegen de marktmacht van de intermediairs;

- Kwaliteits-/ certificeringssysteem voor mestverwerkers gebaseerd op de beoordeling dat processen netjes uitgevoerd worden en de samenstelling/ monstername van de mest op de juiste wijze is vermeld en uitgevoerd.

Niet alle workshopdeelnemers onderschreven dat er marktmacht is bij intermediairs. Dat is niet mogelijk als er zo'n 800 intermediairs zijn.

Over het kwaliteits- en certificeringssysteem werd gezegd dat er een eerste begin mee is gemaakt om dit te realiseren. Het systeem is echter nog wel beperkt. Uiteindelijk zou de hele keten gecertificeerd moeten worden, inclusief het product. Als de certificering er is, zou de overheid een stapje terug kunnen doen zodat er capaciteit overblijft voor probleemgevallen. De sector zou hier meer verantwoordelijkheid naar zich toe moeten trekken.

Institutionele oplossingen om strenger en gerichter te kunnen handhaven

Tijdens de interviews werd ook veel gesproken over de noodzaak om strenger en gerichter te handhaven. Dit wordt hieronder samengevat:

- Transparantie in de mestmarkt; stroom mest van producent naar eindgebruiker moet gemakkelijk te volgen zijn;

- Een betere check op onmogelijke uitkomsten bij RVO is nodig;

- Risicoprofielen opstellen en controles richten op intermediairs met de hoogste risico's;

- Meer controles en zwaardere sancties. Zaken die niet kunnen, niet accepteren. Het duurt te lang voordat iemand veroordeeld wordt en er wordt te weinig ingegrepen, lik op stuk beleid is nodig;

- Dossier opbouwen voor intermediairs om bewijslast rond te krijgen;

- Nu worden vooral 'kleine fraudes aangepakt. Niet zo zinvol. Overheid zou zich op excessen moeten richten;

- Handhavers/ controleurs juiste tools geven om fraudeurs aan te kunnen pakken;

- Klokkenluiders (maar zelfs dan nog moeilijk te bewijzen voor NVWA).

Vanuit de workshop kwam naar voren dat al gewerkt werd aan deze oplossingen. Uit de interviews blijkt echter dat dit in de praktijk niet zo wordt beleefd. Het beeld is dat men er mee weg komt als men fraudeert. Dit beeld zou gekanteld moeten worden. Misschien moet de overheid dus vaker en zichtbaarder handhaven. Een belangrijke vraag die dan naar voren komt is wat het effect hiervan zal zijn op de markt.

Uit de workshop en de interviews kwam ook naar voren dat fraude vooral optreedt bij export van dikke fractie (waarvan de dunne fractie dan zwart in Nederland wordt afgezet) omdat controle en borging in het buitenland niet gelijk zijn aan die in Nederland. De verschillende systemen zouden op elkaar moeten worden afgestemd en er zou meer samenwerking met het buitenland moeten komen. 
Institutionele oplossingen over de wijze van bemonsteren

Hierover werd het volgende gezegd tijdens de interviews:

- Onafhankelijke monstername zal fraude verminderen (als onafhankelijke monsternemers niet beïnvloedbaar zijn). Zoeken naar werkbaar systeem, bijvoorbeeld met voortschrijdend gemiddelde, vergezeld van certificeringssysteem met tweede lijns toezicht door NVWA;

- Betrouwbaarheidscategorieën opzetten voor intermediairs en frequentie van bemonsteren daarop afstemmen;

- Rekening houden met onzekerheidsmarges; nu zo nauwkeurig dat het moeilijk is mestboekhouding sluitend te krijgen ook als je het goed wil doen. Werkt fraude in de hand om mestboekhouding toch sluitend te krijgen. Marges vaststellen voor productie en gehalten van mest en daarop strenger handhaven, lik op stuk beleid als zaken niet kloppen;

- Door onduidelijkheid over wat er in de mest zit, zou niet afgerekend moeten worden op jaarcijfers maar op gemiddelde waardes over 3 of 4 jaar;

- Mestwetgeving eenvoudiger maken.

Tijdens de workshop werd hierover gezegd dat er al gewerkt wordt aan het realiseren van onafhankelijke monstername.

Over de betrouwbaarheidscategorieën werd gezegd dat deze er waarschijnlijk al zijn. Deze zouden zich behalve op intermediairs ook op risicovolle mestsoorten kunnen richten. Ook zou al rekening gehouden worden met onzekerheidsmarges maar dat wordt niet bekend gemaakt. Het is immers niet handig als ondernemers dat weten. Het afrekenen op gemiddelde waardes over 3 of 4 jaar gebeurt al in de akkerbouw voor fosfaat. Voor stikstof geldt dat echter nog niet omdat dat niet kan volgens de nitraatrichtlijn.

Intermediairs hoeven geen verantwoording hoeven af te leggen over stikstof en producenten van dierlijke mest wel.

\section{Ruimte voor ondernemers die het goed doen}

Tijdens de interviews werd ook regelmatig gepleit voor ruimte voor ondernemers die een goed milieukundig resultaat hebben. Dit wordt hieronder samengevat:

- De juiste mindset van ondernemers is belangrijk. Daarmee is het mogelijk goed voor het gewas en voor het milieu te zorgen. Dat zou meer gestimuleerd moeten worden, bijvoorbeeld door ondernemers die het goed doen de ruimte te geven om wel volgens de landbouwkundige adviezen te bemesten;

- Stimulerend kader om het goede te doen in plaats van ge- en verboden;

- Niet nog meer regels, dan krijg je weer nieuwe vormen van fraude;

- Mestbeleid moet in samenwerking met de praktijk regelgeving opzetten;

- Beloningssysteem: iemand belonen als het vijf jaar is goed gegaan;

- In wiens belang is het frauderen? Doe iets aan dat belang.

Tijdens de workshop werd hier nog aan toegevoegd dat er meer bedrijfsspecifieke normen zouden moeten komen voor goede ondernemers mits zij in staat zijn het milieukundig resultaat te behouden. Bij een hogere productie zou het ook mogelijk moeten zijn om meer te bemesten met behoud van milieukundig resultaat. Op die manier kunnen ondernemers worden aangesproken op hun ondernemerschap. 
Wageningen Economic Research Postbus 29703

2502 LS Den Haag

T 0703358330

Ecommunications.ssg@wur.nl

www. wur.nl/economic-research

Wageningen Economic Research RAPPORT

2018-057
De missie van Wageningen University \& Research is 'To explore the potential of nature to improve the quality of life'. Binnen Wageningen University \& Research bundelen Wageningen University en gespecialiseerde onderzoeksinstituten van Stichting Wageningen Research hun krachten om bij te dragen aan de oplossing van belangrijke vragen in het domein van gezonde voeding en leefomgeving. Met ongeveer 30 vestigingen, 5.000 medewerkers en 10.000 studenten behoort Wageningen University \& Research wereldwijd tot de aansprekende kennisinstellingen binnen haar domein. De integrale benadering van de vraagstukken en de samenwerking tussen verschillende disciplines vormen het hart van de unieke Wageningen aanpak. 



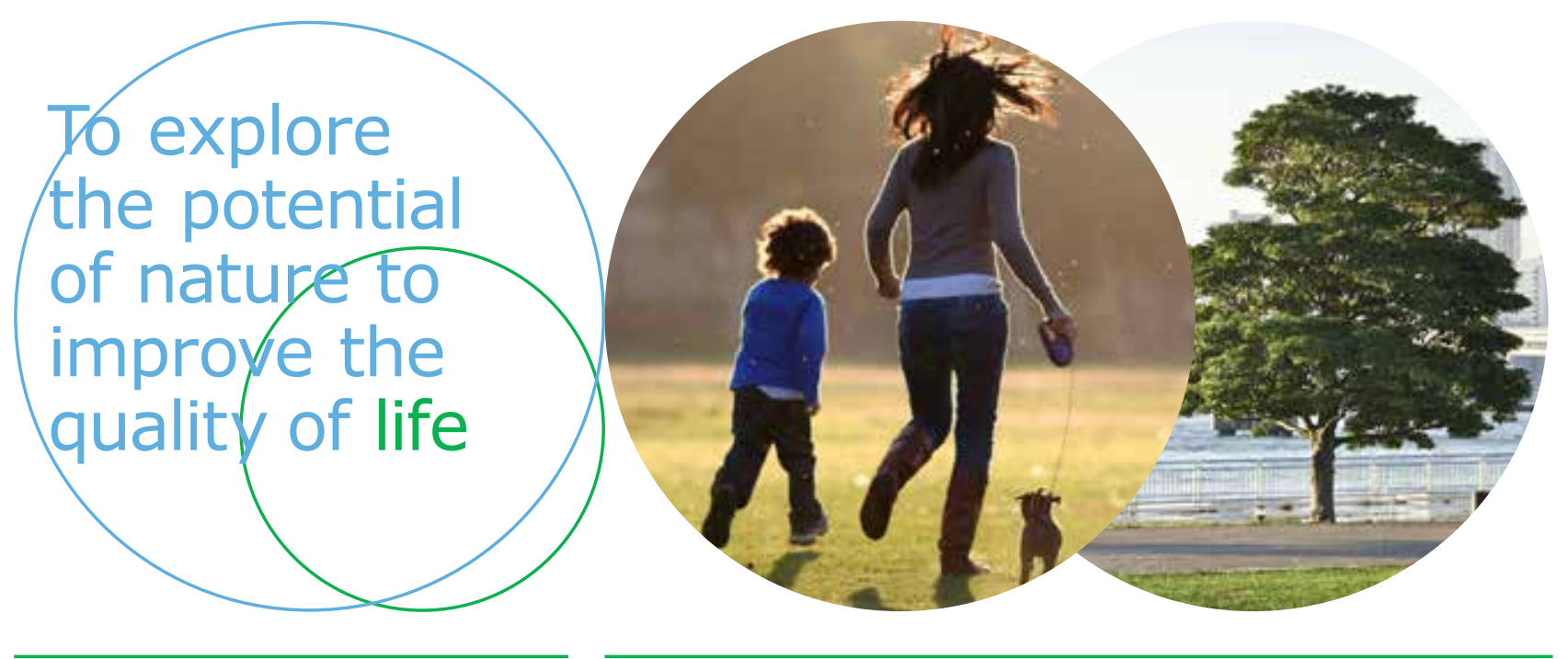

Wageningen Economic Research Postbus 29703

2502 LS Den Haag

E communications.ssg@wur.nl

T +31 (0)7033583 30

www.wur.nl/economic-research

Rapport 2018-057

ISBN 978-94-6343-043-2
De missie van Wageningen University \& Research is 'To explore the potential of nature to improve the quality of life'. Binnen Wageningen University \& Research bundelen Wageningen University en gespecialiseerde onderzoeksinstituten van Stichting Wageningen Research hun krachten om bij te dragen aan de oplossing van belangrijke vragen in het domein van gezonde voeding en leefomgeving. Met ongeveer 30 vestigingen, 5.000 medewerkers en 10.000 studenten behoort Wageningen University \& Research wereldwijd tot de aansprekende kennisinstellingen binnen haar domein. De integrale benadering van de vraagstukken en de samenwerking tussen verschillende disciplines vormen het hart van de unieke Wageningen aanpak. 